\title{
Mixed carbonate-siliciclastic tidal sedimentation in the Miocene to Pliocene Bouse Formation, palaeo-Gulf of California
}

\author{
Brennan O’Connell ${ }^{1,3}$, Rebecca J. Dorsey ${ }^{1}$, Stephen T. Hasiotis ${ }^{2}$, Ashleigh v.s. Hood ${ }^{3}$ \\ ${ }^{1}$ Department of Earth Sciences, University of Oregon, Eugene, OR, United States \\ ${ }^{2}$ Department of Geology, University of Kansas, Lawrence, KS, USA \\ ${ }^{3}$ current, School of Earth Sciences, University of Melbourne, Parkville, Victoria 3051, Australia
}

Post Print October 2020 Sedimentology DOI: 10.1111/sed.12817 


\title{
Mixed carbonate-siliciclastic tidal sedimentation in the Miocene to Pliocene Bouse Formation, palaeo-Gulf of California
}

\author{
Brennan O’Connell ${ }^{1,3}$, Rebecca J. Dorsey ${ }^{1}$, Stephen T. Hasiotis ${ }^{2}$, Ashleigh v.s. Hood ${ }^{3}$ \\ ${ }^{1}$ Department of Earth Sciences, University of Oregon, Eugene, OR, United States \\ ${ }^{2}$ Department of Geology, University of Kansas, Lawrence, KS, USA \\ ${ }^{3}$ current, School of Earth Sciences, University of Melbourne, Parkville, Victoria 3051, Australia
}

Keyword: Colorado River, rhythmites, tidal strait, fluvial-tidal, trace fossils, Thalassinoides

Post Print October 2020 Sedimentology DOI: 10.1111/sed.12817

\section{ABSTRACT}

Mixed carbonate-siliciclastic deposits provide unique insights into hydrodynamic processes that control sedimentation in tidal systems. This study presents sedimentologic and ichnologic data from the upper Miocene to lower Pliocene Bouse Formation, which accumulated during regional transgression at the margin of a tidal strait near the north end of the ancestral Gulf of California.

The basal carbonate member of the Bouse Formation records deposition in a tide-influenced, compositionally mixed carbonate-siliciclastic system dominated by salt marsh, tidal flat, and channel environments. The basal carbonate member is an overall deepening up succession of facies associations (FA) comprising: FA1 siliciclastic-rich heterolithic facies, lime mudstone with desiccation cracks, and plant debris rich carbonate silt interpreted as siliciclastic-rich tidal flats; FA2 well-sorted gravels, siliciclastic-rich sandy strata, lime mudstone with desiccation cracks, and sandy microbial micrite interpreted as tidal-channel deposits; FA3 carbonate-rich heterolithic lime mudstone to well sorted, crossbedded bioclastic grainstone interpreted as intertidal to shallow subtidal deposits; and FA4 lime mudstone interpreted as shallow to deep subtidal low-energy deposits that record the end of tidal conditions in the basin. Trace fossils include marine forms Gyrolithes, Teichichnus, Thalassinoides, and non-diagnostic forms Arenicolites, Cochlichnus, Conichnus, Lockeia, Planolites, Skolithos, and Treptichnus (known from marine, brackish, and freshwater environments). The diminutive size of trace fossils reflects brackish conditions created by mixing of freshwater and seawater. This study provides evidence for a late Miocene to early Pliocene humid climate in southwestern North America, in stark contrast to the modern hyperarid climate. Factors that controlled the relative percent of mixed carbonate and siliciclastic sediment include siliciclastic input from local rivers, in situ carbonate production, current energy, degree of tidal mixing, and relative sea level. Pronounced facies variability at bedform, outcrop, and basin 
scale documented in this study appears to be an important characteristic of mixed carbonate-

36 siliciclastic deposits in tidal depositional systems.

\section{INTRODUCTION}

Mixed carbonate-siliciclastic sediments are common in the geological record and reflect interactions between climate, siliciclastic input, tectonics, basin geometry, transport process, and oceanographic conditions (e.g., Mount et al., 1984; Pilkey et al., 1988; Dolan, 1989; Dorsey \& Kidwell, 1999; Chiarella et al., 2017). Mixed-composition deposits offer a sensitive record of hydrodynamic processes and conditions compared to their pure carbonate or siliciclastic counterparts because of the unique physical properties of carbonate and siliciclastic grains (e.g., Breda \& Preto, 2011; Longhitano, 2011; Chiarella et al., 2017). Mixed carbonate-siliciclastic sediments are also important for hydrocarbon exploration because they are characterised by strong contrasts in permeability and porosity that may influence flow migration and reservoir properties (e.g., McNeill, 2004; Ainsworth, 2010; Chiarella et al., 2017). Despite their significance, mixed carbonate-siliciclastic deposits in the stratigraphic record remain relatively under studied.

A general understanding of mixed carbonate-siliciclastic sedimentation is derived from early work that highlighted classification schemes, styles of mixing, and the role of sea-level change in marine shelf settings (e.g., Zuffa, 1980; Mount, 1984, 1985). The traditional view is that siliciclastic input to marine shelf environments occurs during relative sea-level lowstand, and carbonates are preferentially deposited during highstand when siliciclastic sediment is trapped in estuaries and rivers (e.g., Van Siclen, 1958; Wilson, 1967). Lowstand deposition of carbonate and highstand deposition of sandstone, however, can occur (Brachert et al., 2003), and relative sealevel change is just one of several factors that can act alone or in combination with other processes to control sedimentation in tidal settings. For example, fluvial input of siliciclastic sediment to the

59 Great Barrier Reef is strongly controlled by changes in precipitation, and complex physical mixing 60 of carbonate and siliciclastic sediment often results from base-level changes (e.g., Page \& Dickens, 61 2005). Fluvial input, source mixing, and aeolian input can also contribute to mixing of carbonate 62 and siliciclastic sediment (e.g., Piller \& Mansour, 1994). Tidal and wind currents may circulate 63 siliciclastic sediment that dilutes but does not completely shut off carbonate precipitation (e.g., 64 Zeller et al., 2015). In addition, tectonically controlled changes in palaeoceanographic circulation 
65 can result in variable stacking patterns and mixed sediment composition along the shoreline 66 (Chiarella et al., 2019). These are just a few examples of the processes and factors that control 67 mixed carbonate and siliciclastic deposition in modern and ancient settings.

Recent studies have documented mixed carbonate siliciclastic sediments from microtidal, mixed carbonate siliciclastic deposits of Neogene-Pleistocene tidal bay-fill successions and confined straits of southern Italy, Mediterranean Sea (e.g., Di Stefano \& Longhitano, 2009; Longhitano et al., 2010, 2012a, 2014; Chiarella et al., 2012, 2019; Chiarella \& Longhitano, 2012). The Mediterranean studies are especially insightful because ancient deposits are exposed adjacent to their modern equivalents, allowing researchers to constrain sedimentary processes and stratal geometries in tidal straits and basins. These studies have advanced understanding of deposition in mixed carbonate-siliciclastic microtidal settings, but mixed sedimentation in other types of tidal systems is less well understood. Additional work is needed in areas where interpretation of ancient successions is provided by proximity to comparable modern environments in various tidal settings. Variable parameters of interest include carbonate assemblage type, tidal range, climate, tectonics, amount and type of detrital sediment input, and basin geometry.

The northern Gulf of California region is an excellent natural laboratory to study tidal depositional systems because ancient deposits are exposed close to modern macrotidal flats that provide unique insights into depositional processes and products (Thompson, 1975). The focus of this study is the upper Miocene to lower Pliocene Bouse Formation in its southern exposures along the lower Colorado River region, which accumulated at the margin of a tidal strait near the north end of the ancestral Gulf of California (Fig. 1; O'Connell et al., 2017; Dorsey et al., 2018; Garnder \& Dorsey, in press). The basal carbonate member of the Bouse Formation is characterised by compositional mixing (sensu Chiarella et al., 2017), reflecting contemporaneous accumulation of carbonate and siliciclastic sediment at laminae and bed scales (Chiarella et al., 2017). The Bouse Formation deposits display tidal cyclicity similar to that of the modern Gulf of California (Marinone, 1997; O’Connell et al., 2017), and the tectonic setting and basin geometries are well constrained (Dorsey et al., 2018; Garnder \& Dorsey, in press). Published analyses, however, are incomplete, and some studies favour a lacustrine origin for the Bouse Formation in its southern exposures along the lower Colorado River region (e.g., Spencer \& Patchett, 1997; House et al., 

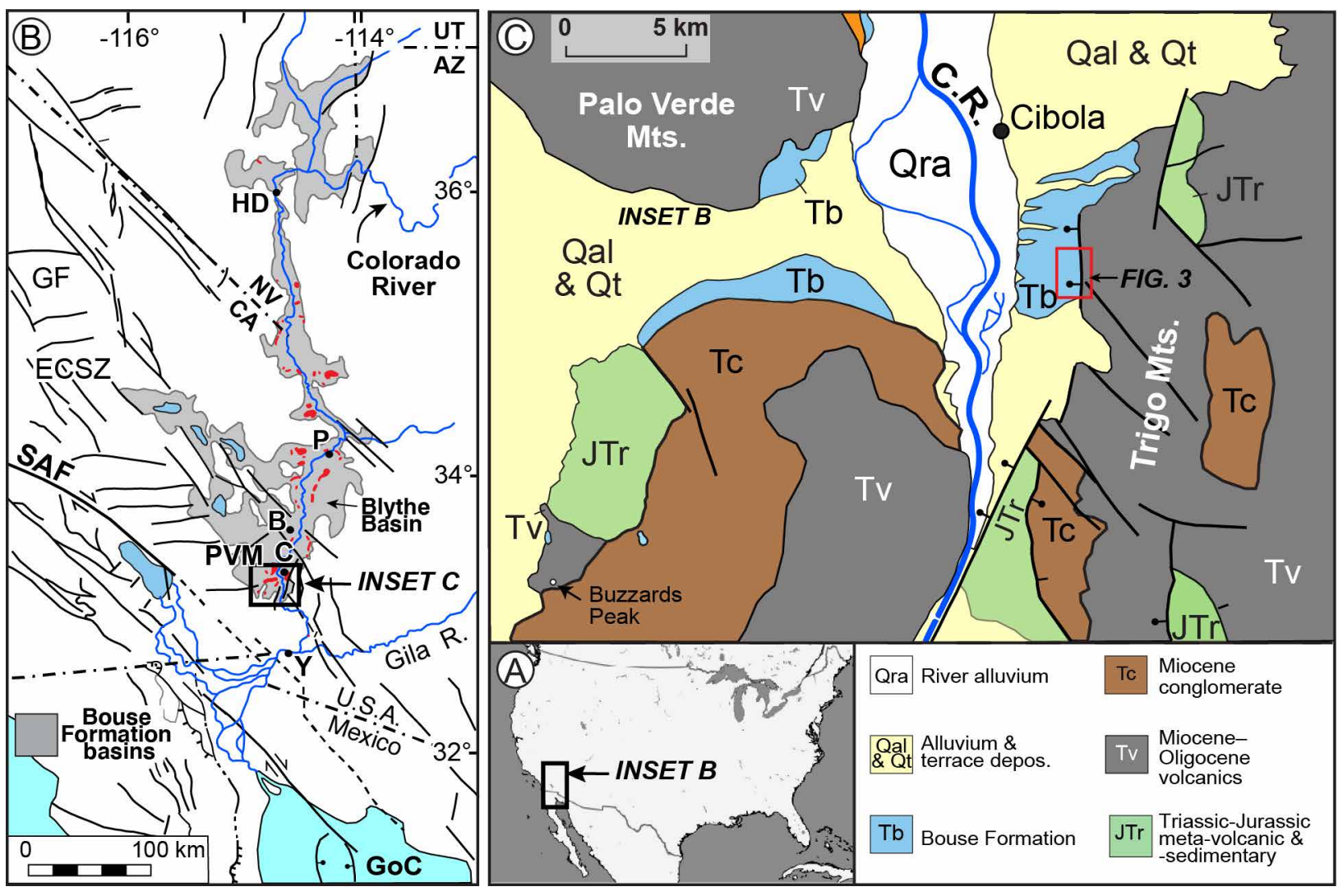

Figure 1. A. Map of USA. B. Map of lower Colorado River region showing major faults, exposures of Bouse Formation (Fm.) (red), and Bouse Formation depositional basins of Spencer et al. (2008) (grey). Abbreviations: B, Blythe; C, Cibola; HD, Hoover Dam; P, Parker; SAF, San Andreas fault; ST, Salton Trough; Y, Yuma; GF, Garlock Fault; ECSZ, Eastern California Shear Zone; GoC, Gulf of California. C. Simplified geologic map of study area (compiled from Sherrod and Tosdal, 1991; Richard, 1993). C.R., Colorado River. Modified from O'Connell et al., (2017).

This paper presents an integrated sedimentologic, ichnologic, petrographic, and palaeoclimatic analysis that sheds new insight into the depositional processes, environments, and climatic setting of the basal carbonate member of the Bouse Formation in its southern exposures. Facies associations documented in this study formed on the low gradient eastern margin of the Blythe basin, in contrast to age-equivalent facies that accumulated on the steeper west margin of the basin in the southeastern Palo Verde Mountains (Fig. 1; Garnder \& Dorsey, in press). Different facies models, therefore, are required despite the proximity of deposits. This study includes a systematic, detailed facies analysis to establish the setting and depositional environments for the 5.0-6.5 Ma northern Gulf of California. Data are then compared to the present day Gulf of California where tidal cyclicity, tidal range, and depositional facies are known (e.g., Thompson, 
114 1975; Halfar et al., 2004), providing an excellent modern analogue for tidal currents and processes.

115 This study advances an understanding of mixed carbonate-siliciclastic settings in general, and

116 provides a facies model to aid in recognising similar settings in the geological record.

\section{REGIONAL GEOLOGY}

119 The Bouse Formation is a widespread, upper Miocene to lower Pliocene succession of 120 carbonate and siliciclastic deposits exposed discontinuously along the lower Colorado River 121 corridor (Figs. 1, 2). The study area is located southeast of Cibola, Arizona, at the eastern margin 122 of the southern Blythe basin (Figs. 1, 3), where prior geologic mapping established the distribution 123 and relative age relations of Miocene to Quaternary deposits (Homan, 2014; Gootee et al., 2016). 124 The Bouse Formation in the studied area formed at the margin of a tidal strait near the north end 125 of the Gulf of California oblique rift as indicated by marine and brackish-water fossils and a wide 126 range of tidal sedimentary structures (e.g., Buising, 1990; Turak, 2000; McDougall, 2008; 127 McDougall \& Miranda-Martinez, 2014; O’Connell et. al., 2017; Dorsey et al., 2018; Garnder \& 128 Dorsey, in press). Although some authors favour an isolated inland-lake model for the Bouse 129 Formation in the study area (Spencer \& Patchett, 1997; House et al., 2008; Spencer et al., 2008, 130 2013; Bright et al., 2016, 2018a; 2018b), the lacustrine model is incompatible with abundant 131 evidence for intertidal, marine to brackish-water fossils and trace fossils, and widespread tide132 influenced sedimentary structures (Buising, 1990; Turak, 2000; O'Connell et al., 2017; Dorsey et 133 al., 2018; Garnder \& Dorsey, in press).

134 The Bouse Formation in the study area is divided into three laterally persistent members: 135 basal carbonate member, siliciclastic member, and upper bioclastic member (Dorsey et al., 2018). 136 The Bouse Formation rests unconformably on Miocene alluvial-fan conglomerate consisting of 137 poorly sorted sandy conglomerate and pebbly sandstone with clasts of volcanic, intrusive, and 138 metamorphic rocks (Fig. 2), representing pre late Miocene basin fill that accumulated in 139 extensional and transtensional basins prior to late Miocene marine incursion and deposition of the 140 Bouse Formation (e.g., Buising, 1990; Sherrod \& Tosdal, 1991; Richard, 1993; House et al., 2008; 141 Spencer et al., 2008, 2013; Homan, 2014). 


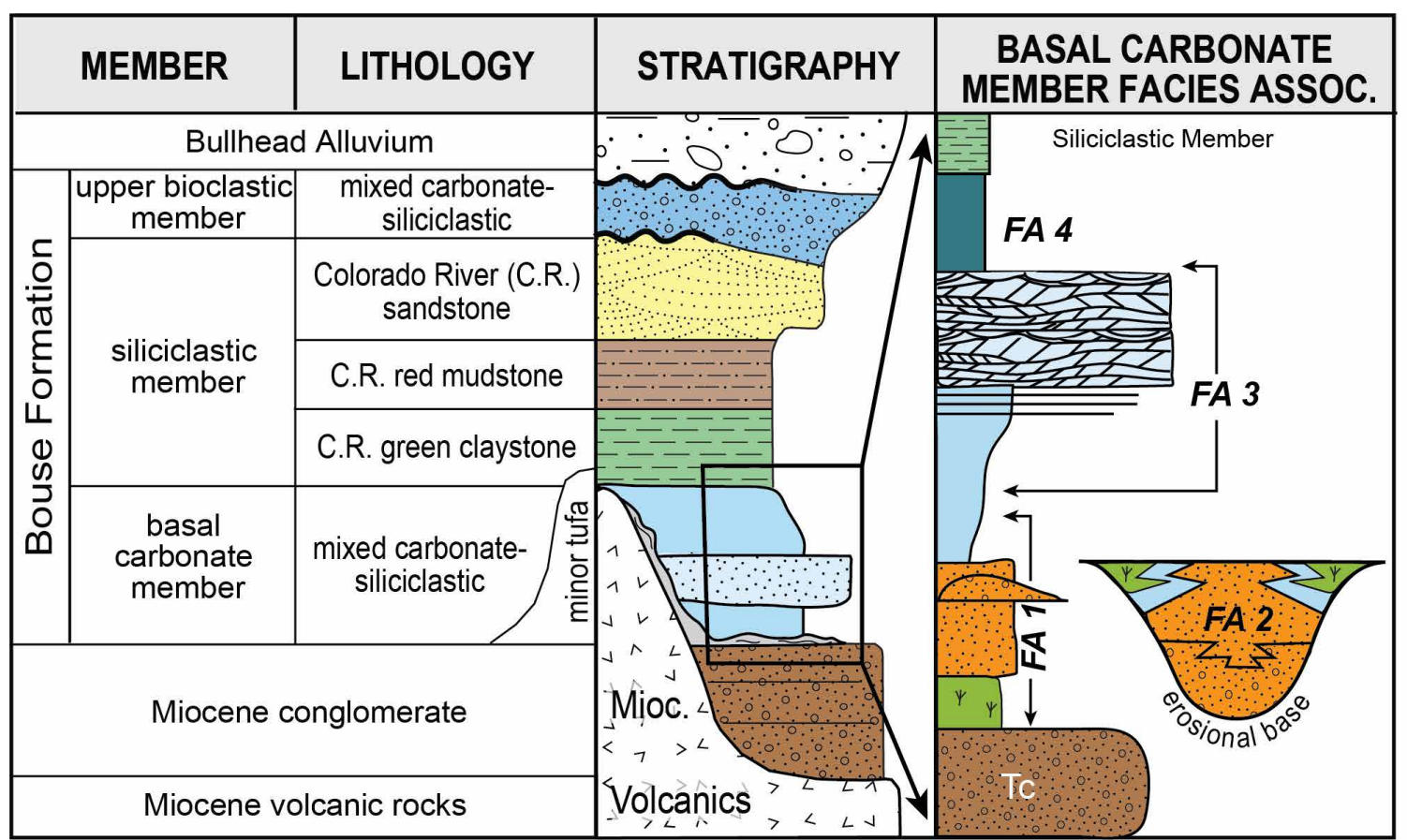

143 Figure 2. Representative members, lithology, and stratigraphy of southern exposures of Bouse 144 Formation along the lower Colorado River. Modified from Homan (2014) and Dorsey et al. 145 (2018). Tc, Miocene conglomerate; FA, Facies association.

The basal carbonate member of the Bouse Formation ranges from $\sim 0.5$ to $15 \mathrm{~m}$ thick and includes: (1) rare bedrock-encrusting travertine and tufa that records the first arrival of carbonateoversaturated waters fed by deeply-sourced groundwater and carbonate-oversaturated freshwater

150 (Crossey et al., 2015, 2017); (2) mixed carbonate-siliciclastic deposits; and (3) and upper lime mudstone (Fig. 2). This study focuses on mixed carbonate-siliciclastic facies and lime mudstone

152 facies exposed on the east side of the Blythe basin (Figs. 1, 2, 3). In the SE Palo Verde Mountains 153 west of the Colorado River (Fig. 1C), the basal carbonate member contains an age-equivalent suite 154 of facies that record marine transgression of a steep rocky shoreline followed by subtidal deposition of coarse bioclastic dunes in a high-energy tidal strait (Garnder \& Dorsey, in press).

156 The siliciclastic member of the Bouse Formation conformably but sharply overlies the 157 basal carbonate member, and displays thickness ranging from $0 \mathrm{~m}$ at basin margins to $200 \mathrm{~m}$ in 158 the subsurface (Metzger et al., 1973). The siliciclastic member is comprised of Colorado River159 derived claystone, siltstone, and crossbedded deltaic and river channel sandstone, and records the 160 first arrival of Colorado River sediment (Fig. 2; Homan, 2014; Dorsey et al., 2018). The upper 161 bioclastic member unconformably overlies the lower two members and consists of water-lain, 
162 mixed carbonate-siliciclastic calcarenite, pebbly calcarenite, and calcareous-matrix conglomerate 163 (Fig. 2; Homan, 2014; Dorsey et al., 2018). The Bullhead Alluvium and younger Quaternary 164 terrace gravels erosionally overlie the Bouse Formation (Fig. 2; House et al., 2008; Howard et al., 165 2015).

166

\section{METHODS}

168 Fourteen stratigraphic sections - including two detailed sections with ichnofossil data (Fig. 169 4) -were selected as representative examples from measured sections in the study area (see 170 O'Connell, 2016). Stratigraphic sections were measured in exposed cut banks of desert washes 171 (Fig. 3) at the cm- to m-scale using a Jacob's staff. All stratigraphic sections begin at the wash 172 bottom and end at the top of exposed beds - either the top of the Bouse Formation or the top of 173 erosionally inset younger Quaternary terrace gravels. Stratigraphic sections were measured 174 generally 50-200 m apart, depending on outcrop accessibility and stratigraphic completeness. 175 


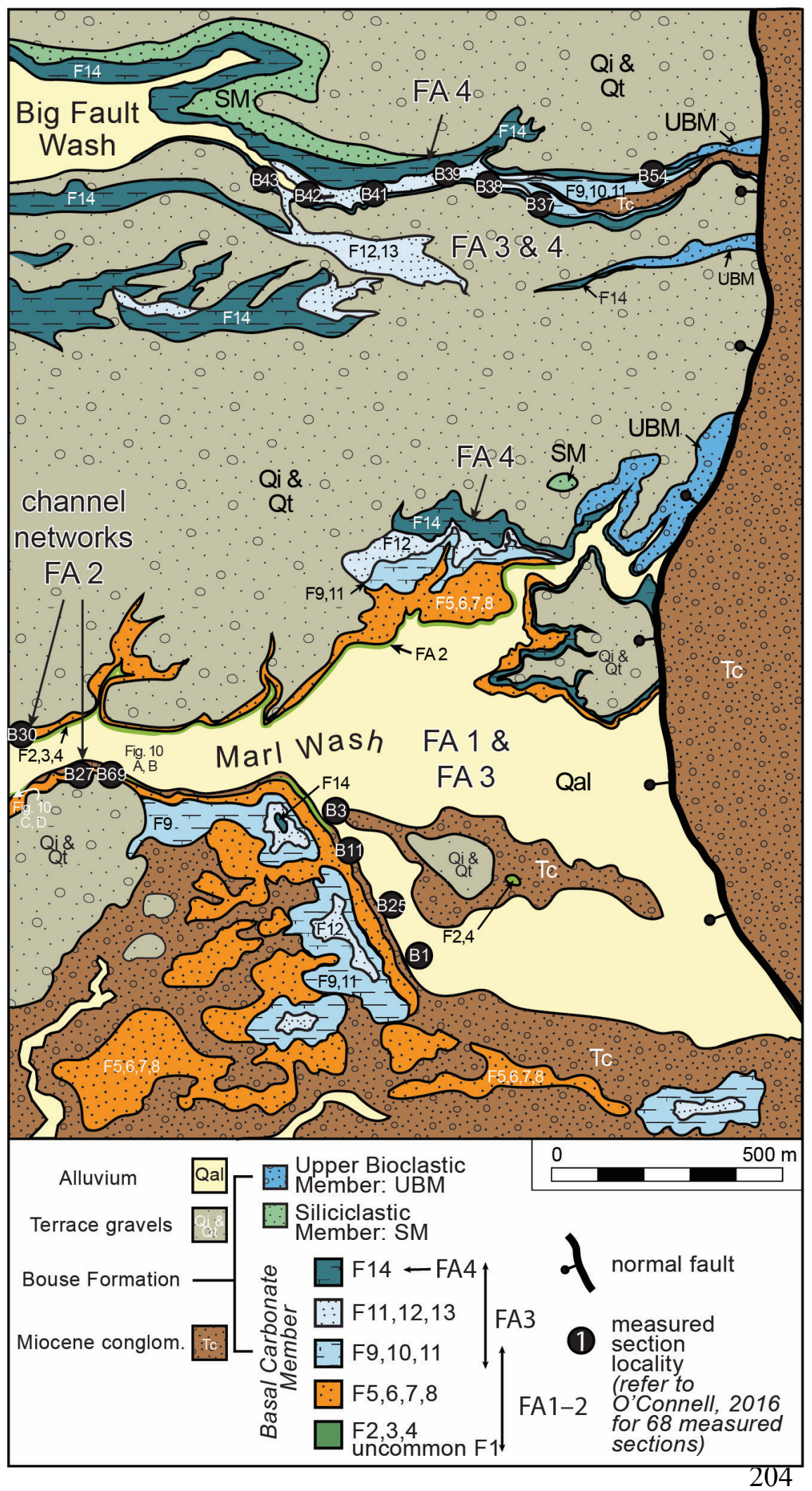

Figure 3. Detailed geologic map of study locations south of Cibola, AZ. Modified from Gootee et al., 2016. See Fig. 1 for regional view. 
205 Data collected include lithology and texture (grain size and sediment sorting), bed 206 thickness and bed geometry at the bedform and outcrop scale, sedimentary structures, and 207 ichnofossils. Palaeocurrent measurements were taken where three-dimensional (3D) surfaces were 208 exposed and accessible. The bioclastic/siliciclastic ratio (b/s) and segregation index (SI) are used 209 to document the carbonate-siliciclastic percentages and the degree of segregation of particles 210 (sensu Chiarella \& Longhitano, 2012). Sediment was considered unmixed if the antithetic 211 component was $<10 \%$ (Mount, 1985; Chiarella \& Longhitano, 2012). Measured sections were 212 correlated in the field using such key stratigraphic surfaces as Thalassinoides-bearing beds, well213 cemented beds, or the base of the lime mudstone facies sharply overlying tidal deposits. These key 214 contacts were walked out to document lateral facies transitions. Trace fossils were identified by 215 their architectural and surficial morphologies and fill type (Hasiotis \& Mitchell, 1993; Bromley, 216 1996). Samples were collected within measured sections and in laterally equivalent beds. 217 Representative samples were taken for thin section petrographic analysis. 


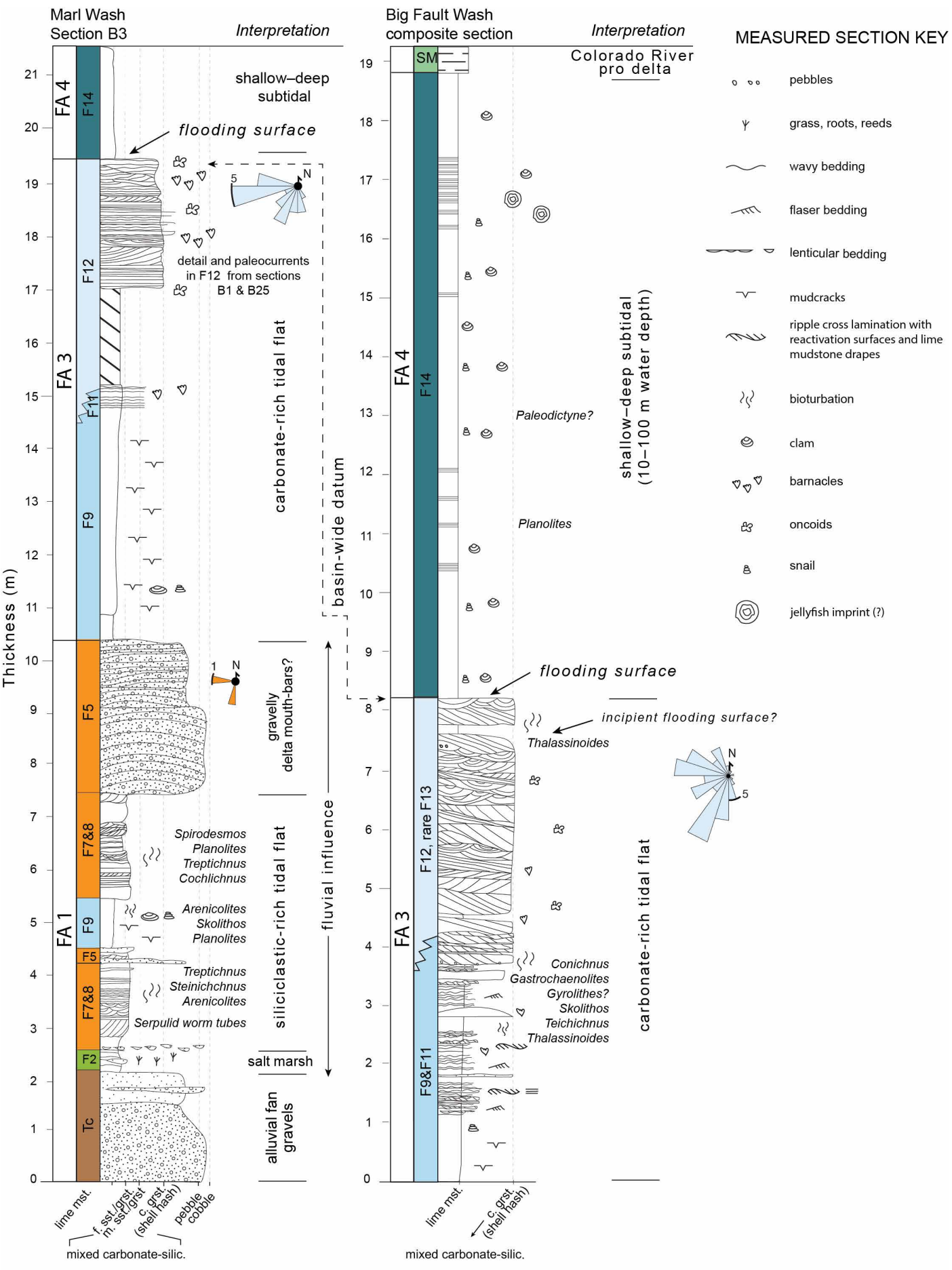

220 Figure 4. Detailed stratigraphic sections from Marl Wash and Big Fault Wash localities (see Fig. 221 3). FA, Facies Association; F, Facies (see Table 1); Tc, Miocene conglomerate. 


\section{FACIES ASSOCIATIONS}

This study documents 14 facies (Table 1) that are identified based on lithology and texture

227 (grain size and sediment sorting), bed thickness, geometry at the bedform and outcrop scale, 228 sedimentary structures, fossil content and ichnofossil data, and the degree of bioclastic-siliciclastic 229 mixing (b/s) (sensu Chiarella \& Longhitano, 2012). A detailed description of facies is provided in 230 Table 1. From these 14 facies (F), four facies associations (FA) (Fig. 2; Table 2) are recognised 231 and described in detail. Facies associations were grouped based on the common and predictable 232 occurrence of facies in the stratigraphy, as well as such lateral and vertical facies relationships as 233 common interbedding or lateral equivalence. Facies associations are described in their typical 234 stratigraphic order from the base to the top of the basal carbonate member. Facies associations 12354 are present in the Marl Wash area, and FA3-FA4 with minor FA1 are present in Big Fault Wash 236 (Fig. 3). This analysis excludes a distinctive freshwater tufa and travertine unit at the base of the 237 basal carbonate member of the Bouse Formation elsewhere (e.g., Palo Verde Mountains; Crossey 238 et al., 2017; Dorsey et al., 2018) but is absent in the area south of Cibola, Arizona, where this study 239 is focused (Figs. 1C; 3).

\section{Facies Association 1 (FA1): Siliciclastic-rich tidal flats}

Sedimentology: This facies association (Table 2; Figs. 4-7) includes the following facies: 243 cobble lag (F1), matted plant debris rich carbonate silt (F2), thinly bedded poorly sorted 244 conglomerate (F4), crossbedded well-sorted conglomerate (F5), crossbedded sandstone (F6), 245 ripple-laminated calcareous sandstone (F7), heterolithic bedding (F8), and lime mudstone with 246 desiccation cracks (F9) (Tables 1, 2). This association is dominated by compositionally mixed 247 (carbonate-siliciclastic) strata. The carbonate-siliciclastic fraction is generally $\sim 50: 50(\mathrm{~b} / \mathrm{s}=1)$ 248 (F2, F6, F7 F8), although the siliciclastic fraction can be $\sim 70 \%(\mathrm{~b} / \mathrm{s}<1)(\mathrm{F} 4, \mathrm{~F} 7)$ or can exceed $24990 \%(\mathrm{~b} / \mathrm{s}<<1)(\mathrm{F} 1, \mathrm{~F} 5$, rare F6 and F7). The siliciclastic fraction drops to $\sim 10 \%(\mathrm{~b} / \mathrm{s}>>1)$ or 250 unmixed in some carbonate-rich heterolithic beds of F8 and F9.

251 These facies are grouped together because they are closely interbedded and laterally 252 equivalent deposits (Figs. 4, 5). Centimetre- and m-scale interbedding is common in these deposits, 253 as are lateral facies changes over the m-scale. For example, the base of FA 1 is generally 254 interbedded plant debris rich facies (F2) and conglomerate (F4) (and rare F1) (Figs. 4, 5). These 255 facies are overlain by interbedded flat-based, well-sorted gravels (F5), well-sorted sandy (F7), and 
TABLE 1. Bouse Formation basal carbonate member facies

\begin{tabular}{|c|c|c|c|c|c|c|c|c|c|}
\hline $\begin{array}{l}\text { Facies } \\
\text { Name }\end{array}$ & $\underset{\#}{\text { acies }}$ & Lithofacies description & $\begin{array}{l}\text { Sedimentary } \\
\text { structures }\end{array}$ & $\begin{array}{l}\text { Ichnology/ } \\
\text { fossil content/ } \\
\text { plant material }\end{array}$ & $\begin{array}{l}\text { Bed } \\
\text { thickness }\end{array}$ & $\begin{array}{l}\text { Typical } \\
\text { b/s ratio }\end{array}$ & $\begin{array}{l}\text { Sedimentary } \\
\text { process }\end{array}$ & $\begin{array}{l}\text { Interpretation of } \\
\text { depositional } \\
\text { environment }\end{array}$ & \\
\hline Cobble lag & 1 & $\begin{array}{l}\text { Well sorted locally derived volcaniclastic cobbles distrib- } \\
\text { uted as a single-clast horizon at the base of the basal } \\
\text { carbonate member. Lack of fine-grained sediment. } \\
\text { Occasional rounded and reworked carbonate clasts. Rare } \\
\text { facies in Marl Wash and Big Fault Wash. }\end{array}$ & & & $15-20 \mathrm{~cm}$ & $\begin{array}{l}\text { unmixed } \\
\text { (siliciclastic) }\end{array}$ & $\begin{array}{l}\text { Winnowing, rework- } \\
\text { ing, and concentrating } \\
\text { cobble clasts derived } \\
\text { from Miocene } \\
\text { alluvial-fan conglom- } \\
\text { erate and earliest } \\
\text { Bouse carbonates. }\end{array}$ & $\begin{array}{l}\text { Conglomerate possibly } \\
\text { associated with a sequence } \\
\text { boundary; F1 at base of FA2 } \\
\text { is a gravelly channel lag. }\end{array}$ & \multirow{5}{*}{ 个| } \\
\hline $\begin{array}{l}\text { Matted } \\
\text { plant debris } \\
\text { rich } \\
\text { carbonate } \\
\text { silt }\end{array}$ & 2 & $\begin{array}{l}\text { Thin beds of matted mixed carbonate-siliciclastic silt } \\
\text { drape underlying strata. Extremely rare gypsum pseudo- } \\
\text { morphs. Some beds recessive, poorly-sorted, weakly } \\
\text { laminated to massive carbonate-sandy lime mudstone. }\end{array}$ & $\begin{array}{l}\text { Wavy } \\
\text { bedding; } \\
\text { pinch-and } \\
\text {-swell along } \\
\text { bedding } \\
\text { planes }\end{array}$ & $\begin{array}{l}\text { Abundant carbonate } \\
\text { plant debris material } \\
\text { (grasses, reed casts, } \\
\text { root casts) } \\
\text { (Figs. 6E, } 7 \mathrm{~B} \text { ) }\end{array}$ & $0.1-2 \mathrm{~cm}$ & $\mathrm{~b} / \mathrm{s}=1$ & $\begin{array}{l}\text { Deposition from } \\
\text { occasional flooding, } \\
\text { baffling, and sediment } \\
\text { entrapment in highly- } \\
\text { vegetated marshes; } \\
\text { rooting; exposure; } \\
\text { rare evaporite mineral } \\
\text { formation. }\end{array}$ & $\begin{array}{l}\text { Supratidal salt marsh; } \\
\text { extrememly rare evaporite } \\
\text { mineral formation may } \\
\text { indicate deposition in a } \\
\text { humid climate. }\end{array}$ & \\
\hline $\begin{array}{l}\text { Sandy } \\
\text { microbial } \\
\text { micrite }\end{array}$ & 3 & $\begin{array}{l}\text { Mixed composition silicified sandy microbial micrite. } \\
\text { Siliciclastic portion can exceed } 50 \% \text {. Commonly found } \\
\text { along the margins of channel deposits (FA2). Weathers } \\
\text { into well-cemented large slabs. }\end{array}$ & $\begin{array}{l}\text { Irregular } \\
\text { laminations; } \\
\text { can be } \\
\text { massive }\end{array}$ & $\begin{array}{l}\text { Vertebrate tracks include } \\
\text { felines, horses, elephants, } \\
\text { and camels; charophytes } \\
\text { (Sarjeant et al., 2002; } \\
\text { Sarjeant \& Reynolds } \\
\text { 2001; Metzger, 1968 }\end{array}$ & 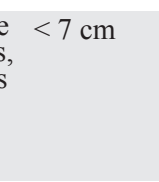 & $\mathrm{b} / \mathrm{s}=1$ & & $\begin{array}{l}\text { Upper intertidal to supratidal } \\
\text { algal marsh along the margins } \\
\text { of channels (FA2). }\end{array}$ & \\
\hline $\begin{array}{l}\text { Thinly } \\
\text { bedded } \\
\text { poorly sorted } \\
\text { conglom. }\end{array}$ & 4 & $\begin{array}{l}\text { Locally includes } \sim 7 \text { - to } 10 \text {-cm thick beds of poorly sorted } \\
\text { locally-derived granular sandy conglomerate with sharp } \\
\text { erosional bases and tops. Carbonate and siliciclastic-rich } \\
\text { matrix. Clasts angular to sub-rounded, with matrix-sup- } \\
\text { ported pebbles concentrated at base. Associated with F2. }\end{array}$ & $\begin{array}{l}\text { No imbrica- } \\
\text { tion }\end{array}$ & & $\sim 7-10-\mathrm{cm}$ & $\begin{array}{l}\mathrm{b} / \mathrm{s}<1 \\
\text { to } \\
\text { unmixed } \\
\text { (siliciclastic) }\end{array}$ & & $\begin{array}{l}\text { Pebbly gravel beds may } \\
\text { represent accumulation at the } \\
\text { base of small runoff-channels } \\
\text { in this local catchment, or } \\
\text { tidal creek deposits. }\end{array}$ & \\
\hline $\begin{array}{l}\text { Crossbedded } \\
\text { well-sorted } \\
\text { conglom. }\end{array}$ & & $\begin{array}{l}\text { Golden brown to gray green, rounded to subrounded, } \\
\text { well-sorted to extremely well-sorted, coarse siliciclastic } \\
\text { sandstone and pebble-cobble conglomerate. Systematic } \\
\text { up slope and down slope variations in grain size occur in } \\
\text { foresets. These deposits are often discontinuous laterally, } \\
\text { exhibiting strongly lenticular geometry. Sometimes } \\
\text { domed or planar geometries (Fig. 6A). Primary dips } \\
\text { ranging from nearly horizontal to steep foresets } \\
\left(\sim 20-30^{\circ}\right) \text {. Gravels can have a lack of fine-grained matrix } \\
\text { material (open-networks). Interbeds of carbonate-rich } \\
\text { sand are locally present. Clasts consist primarily of } \\
\text { granitic and intermediate plutonic, volcanic breccia, and } \\
\text { unwelded volcanic tuff. If present, matrix is mixed } \\
\text { carbonate and siliciclastic sand. Pebble beds, } 1-3 \text { granule } \\
\text { to small pebble grains thick, can extend laterally from toe } \\
\text { of lenticular cross-bedded gravel foresets. }\end{array}$ & $\begin{array}{l}\text { Inverse, } \\
\text { normally } \\
\text { graded, and } \\
\text { ungraded } \\
\text { beds. }\end{array}$ & & $\begin{array}{l}\text { Tabular } \\
\text { cross } \\
\text { stratified- } \\
\text { crossbed sets } \\
0.5-3 \mathrm{~m} \\
\text { pebble beds } \\
1-3 \mathrm{~cm}\end{array}$ & $\begin{array}{c}\mathrm{b} / \mathrm{s}<1 \\
\text { to } \\
\text { unmixed } \\
\text { (siliciclastic) }\end{array}$ & $\begin{array}{l}\text { Sediment delivered by } \\
\text { small local catchments } \\
\text { and transported, } \\
\text { reworked, and deposit- } \\
\text { ed by migrating } \\
\text { gravelly bedforms. }\end{array}$ & $\begin{array}{l}\text { These gravels likely represent } \\
\text { a range of bedforms and are } \\
\text { typically found at the base of } \\
\text { channel fill (FA2) and as } \\
\text { gravelly bedforms in relative- } \\
\text { ly siliciclastic tidal flat } \\
\text { deposits (FA1). Some gravel } \\
\text { bedforms may represent } \\
\text { channel fill, barchan dunes, } \\
\text { delta mouth bars and/or } \\
\text { gilbert deltas. Additional } \\
\text { work is needed to understand } \\
\text { all conglomerate depositional } \\
\text { environments. }\end{array}$ & \\
\hline $\begin{array}{l}\text { Crossbedded } \\
\text { sst }\end{array}$ & & $\begin{array}{l}\text { Golden brown to gray green, well-sorted fine-medium } \\
\text { grained siliciclastic sandstone. Comprised of same } \\
\text { grain-type lithologies as F5. Associated with minor } \\
\text { barnacle and oncoid packstone. Siliciclastic component } \\
>95 \% \text {. Limited to one basin-margin locality in Big Fault } \\
\text { Wash. }\end{array}$ & $\begin{array}{l}\text { Trough } \\
\text { crossbedding }\end{array}$ & & $50 \mathrm{~cm}$ & $\begin{array}{c}\mathrm{b} / \mathrm{s}=1 \\
\text { to } \\
\text { unmixed } \\
\text { (siliciclastic) }\end{array}$ & $\begin{array}{l}\text { Likely deposited by } \\
\text { unidirectional currents, } \\
\text { although limited 2D } \\
\text { outcrop does not allow } \\
\text { for accurate paleocur- } \\
\text { rent measurements. }\end{array}$ & $\begin{array}{l}\text { Small catchment at interface } \\
\text { of marine environments? }\end{array}$ & $\underbrace{}_{\infty}$ \\
\hline $\begin{array}{l}\text { Ripple-lam. } \\
\text { calcareous } \\
\text { sst }\end{array}$ & 7 & $\begin{array}{l}\text { Sandy calcarenite and calcarenitic sandstone: fine- to } \\
\text { medium- grained, laminated to thick bedded, admixed } \\
\text { carbonate and siliciclastic sandstone (Fig. 6, 7). } \\
\text { Siliciclastic component generally ranges from } 30 \% \text { to } \\
70 \% \text { in the siliciclastic-carbonate mixture (commonly } \\
750 \% \text {, although rarely siliciclastic component can exceed } \\
\sim 90 \%) \text {. }\end{array}$ & $\begin{array}{l}\text { Ripple cross } \\
\text { lamination, } \\
\text { trough and } \\
\text { tabular cross-bed } \\
\text { sets, parallel } \\
\text { lamination, } \\
\text { dessication } \\
\text { cracks, unidirec- } \\
\text { tional, massive } \\
\text { beds; climbing } \\
\text { and combined } \\
\text { flow ripples }\end{array}$ & $\begin{array}{l}\text { Rare horse tracks, } \\
\text { Serpulid worm tubes, } \\
\text { escape burrows assoc. } \\
\text { with unidirectional } \\
\text { ripples } \\
\text { Arenicolites, } \\
\text { Cochlichnus, } \\
\text { Planolites, Spiroes- } \\
\text { mos, Skolithos, } \\
\text { Steinichchnus, } \\
\text { Treptichnus, } \\
\text { Thalassinoides }\end{array}$ & $\begin{array}{l}\text { Beds } \\
20-80 \mathrm{~cm} \\
\text { (FA1); } \\
\text { Cross-strata } \\
\text { up to } 2.8 \mathrm{~m} \\
\text { (FA2) }\end{array}$ & $\begin{array}{l}\mathrm{b} / \mathrm{s}=1 \\
\text { to } \\
\mathrm{b} / \mathrm{s}<1\end{array}$ & $\begin{array}{l}\text { Deposition by tidal } \\
\text { bars and dunes; } \\
\text { systematic hydraulic } \\
\text { sorting of carbonate } \\
\text { and siliciclastic } \\
\text { sediment by tidal } \\
\text { currents. }\end{array}$ & $\begin{array}{l}\text { Tidal bars and dunes on } \\
\text { mixed relatively siliciclas- } \\
\text { tic-rich lower tidal flats } \\
\text { (FA1). Some sandy bedforms } \\
\text { comprise channel fill (FA2). } \\
\text { Fluvial influence. }\end{array}$ & : \\
\hline $\begin{array}{l}\text { Heterolithic } \\
\text { bedding } \\
\text { (silici.-rich) }\end{array}$ & 8 & $\begin{array}{l}\text { Admixed, well-sorted sandy calcarenite, calcarenitic } \\
\text { sandstone, and lime mudstone. Recessive (Fig. } 7 \text { C,D). }\end{array}$ & $\begin{array}{l}\text { Wavy, flaser, } \\
\text { and lenticular } \\
\text { bedding }\end{array}$ & $\begin{array}{l}\text { Similar } \\
\text { assemblage to F7 }\end{array}$ & $0.2-1.5 \mathrm{~m}$ & $\mathrm{~b} / \mathrm{s}=1$ & $\begin{array}{l}\text { Systematic hydraulic } \\
\text { sorting of carbonate } \\
\text { and siliciclastic } \\
\text { sediment by tidal } \\
\text { currents. }\end{array}$ & $\begin{array}{l}\text { Deposition adjacent to } \\
\text { migrating dunes and bars and } \\
\text { on mixed tidal flats. }\end{array}$ & $\downarrow$ \\
\hline
\end{tabular}


TABLE 1 (cont.). Bouse Formation basal carbonate member facies

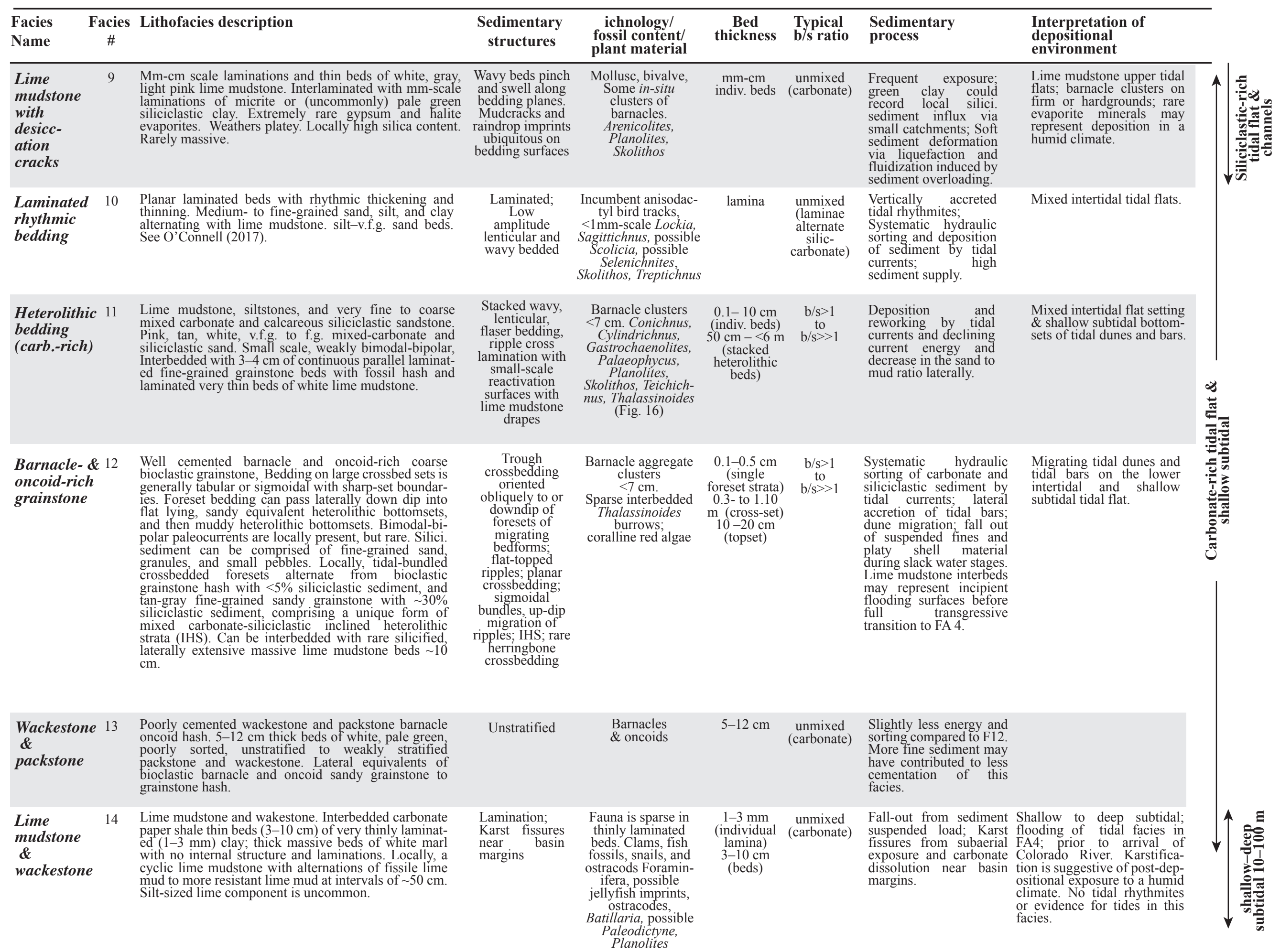


TABLE 2. Bouse Formation basal carbonate member facies associations

\begin{tabular}{lll}
\hline $\begin{array}{l}\text { Facies } \\
\text { Association }\end{array}$ & Facies & Description \\
\hline $\begin{array}{l}\text { FA1: Siliciclastic- } \\
\text { rich tidal flats }\end{array}$ & $1,2,4,5,6,7,8,9$ & $\begin{array}{l}\text { Mixed (carbonate and siliciclastic) siliciclastic-rich interbedded sandy ripple } \\
\text { cross-laminated strata, heterolithic bedding, and lime mudstone with desiccation } \\
\text { cracks. Lateral facies variations common. The base is generally a matted plant-rich } \\
\text { carbonate facies, or rarely a cobble conglomerate. Mixed siliciclastic-rich facies are } \\
\text { interbedded with lenticular and planar crossbedded conglomerates. Extremely rare } \\
\text { evaporites. }\end{array}$
\end{tabular}

\section{Interpretation}
FA2: Tidal-
$1,3,5,7,9$
channel complex
Concave-up strata $(<15 \mathrm{~m})$ with an erosional base, thinning to a few meters on the channel flanks before pinching out. Coarse conglomerate, with common scour surfac- es, comprise the base of channels. Coarse conglomerate is overlain by mixed siliciclastic-rich sandy strata in channel axes. Sand-rich strata pass laterally to lime mudstone passes laterally to mixed silicified sandy microbial clotted carbonates with abundant vertebrate tracks at the outer-most flanks of the channel.

Siliciclastic-rich upper, mixed, and lower tidal flats flanked by salt marsh deposits. Siliciclastic sediment is likely derived from small basin-margin catchments. Association of siliciclastic sediment and carbonate sediment is likely due to carbonate supe saturated waters (i.e. precipitation from seawater supersaturated with respect to carbonate) in the paleo-Gulf of California. Rare evaporites suggest a humid climate.

Deep $<15 \mathrm{~m}$ channel systems. Orientation is uncertain because of 2D exposure. Channels filled with local catchment-derived sediment. Association of siliciclastic sediment and carbonate paleo-Gulf of California. Unclear relationship with FA1, as FA2 erosionally cuts into FA1 as well as the underlying Pre-Bouse Miocene conglomerate. Possible deposition syn-post FA1.

Carbonate-rich upper, middle, lower intertidal and shallow carbonate-rich. Rare evaporites suggest a humid climate. grainstone and lime mudstone, and well-sorted oncoid and barnacle cross-bedded, sion from lime mudstone with desicetion cracks into heterolithic bedded facies an then into crossbedded barnacle- and oncoid-rich bioclastic orainstone facies. Toward the basin center, crossbedded bioclastic facies pass laterally into heterolithic facies that then pass laterally into bioturbated lime mudstone.

\section{FA4: Shallow to deep subtidal (post-tidal)}

Low-energy lime mudstone abruptly stratigraphically above high energy well cemented barnacle and oncoid crossbedded grainstones. Interbedded carbonate laminae, thin beds, and thick massive beds of white marl with no internal structure and laminations. Karst fissures near basin margins.
Post-tidal, shallow to deep subtidal deposition. Accumulated in roughly 10 to $100 \mathrm{~m}$ water depth based on sedimentology and foraminiferal assemblage (Dorsey et al., 2018). Abrupt contact from FA3 to FA4 is likely a basin-wide datum: it is a sharp traceable contact in all localities where this contact can be walked out. Fall-out from whiting events or sediment suspended load; Karst fissures from subaerial exposure and carbonate dissolution or evidence for tidal processes in this facies. 
256 heterolithic facies (F8) that pass laterally or pinch out entirely into ripple-laminated calcareous 257 sandstone (F7) and desiccated lime mudstone (F9) (Figs. 4, 5). $6 \mathrm{~A})$, sometimes associated with the F4 conglomerate facies and rare F1 cobble lag facies. These 260 facies are overlain by interbedded ripple laminated calcareous sandstone (F7), siliciclastic-rich 261 heterolithic bedding (F8), crossbedded gravels (F5), and lime mudstone with desiccation cracks 262 (F9) (Fig 4, section B3; Figs. 5, 6A). Well-sorted gravels (F5) display a range of crossbedding 263 styles from planar-tabular to distinctive convex-up geometries (Figs. 4-6A, 6B). Interbeds of 264 carbonate-rich sand are locally present in F5 (Fig. 6A). Gravels (F5) commonly coarsen up section, 265 have lenticular clinoform geometries, and transition down-dip into individual pebble beds and finer 266 grained deposits (see gravel facies in Fig. 5). On gravel topsets, clotted microbial carbonate is 267 rarely observed to encrust on pebble clasts (Fig. 6C). Well-sorted sandy calcarenite and 268 calcarenitic sandstone (F7, Fig. 4, section B3) is common.

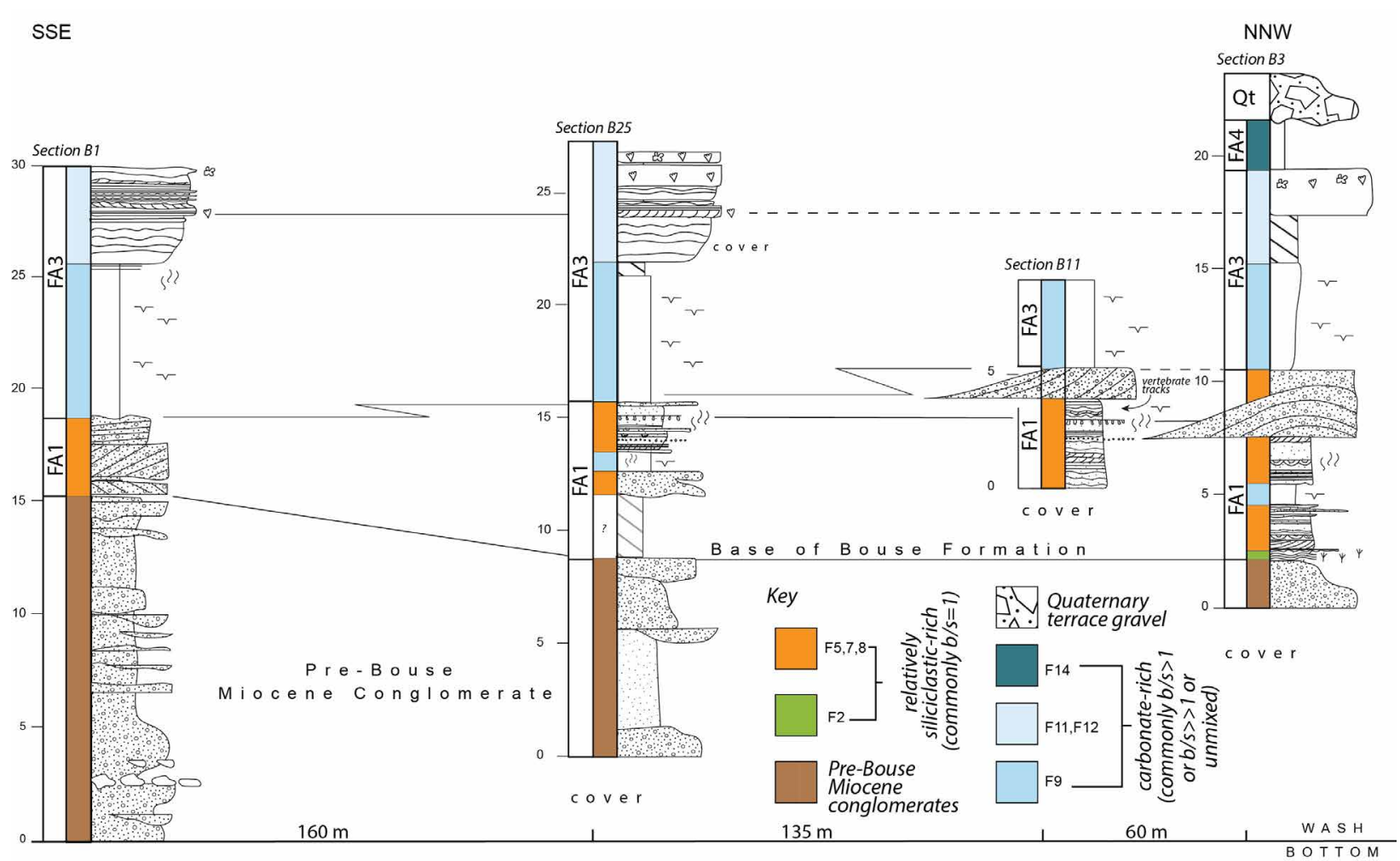

271 Figure 5. Stratigraphic sections and lateral relationships of FA1, FA3, FA4 from Marl Wash (see 272 Fig. 3). Note top of sections B1, B25, and B11 are eroded. 
274 Desiccation cracks are common on nearly every bedding plane of the lime mudstone facies 275 (F9; (Fig. 6D); desiccation cracks are also present in matted plant debris rich carbonate silt (F2; 276 Fig. 6E) and ripple laminated calcareous sandstone (F7; Fig. 6F). Ripple laminations with lime 277 mudstone drapes (F7, Fig. 6G) are also common. Fossil plant debris matter (grasses, rhizoliths as 278 root casts) (F2, Fig. 6E, 7A, B), and wavy, flaser, and lenticular bedding (F8, Fig. 7C, D) are 279 common. Sandy calcarenite and calcarenitic sandstone is well sorted (Fig. 7E, F). There is also 280 frequent interbedding of lime mudstone (F9), heterolithic intervals (F8), gravels (F5) and 281 structureless calcareous sandstones (F7) (Fig 4, section B3, Fig. 6B, 8A) with parallel lamination 282 and unidirectional ripple lamination (Figs. 4, 5, 8B). Evaporites are extremely rare, and were only 283 observed at one locality. 


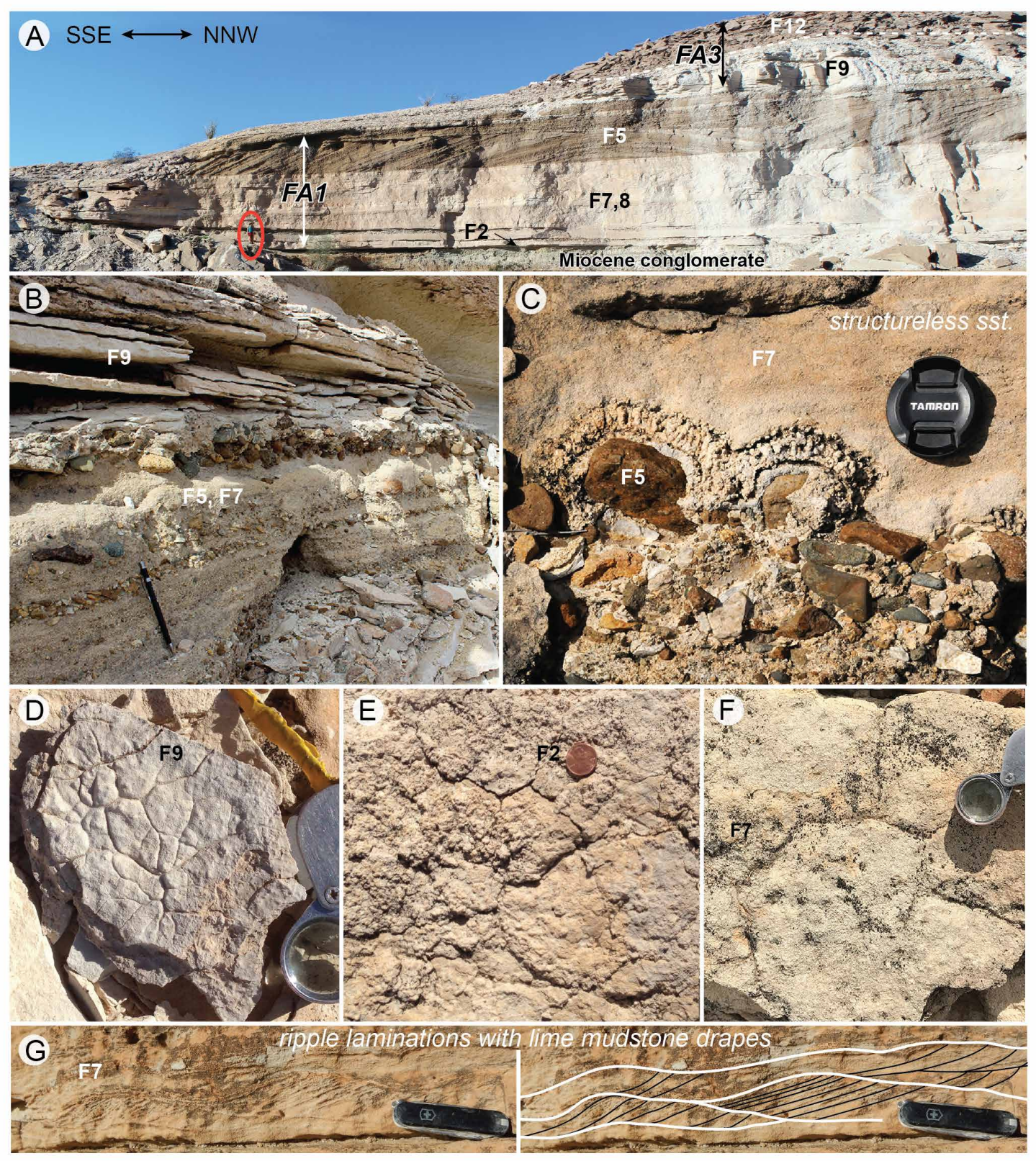

284

285

286

287

288

289

290
Figure 6. Facies association 1 (FA1), siliciclastic-rich tidal flats A-G: A. Overview of FA1. Note person for scale (circled) and orientation of photo. B. Interbedded gravels, sands, and lime mudstone with desiccation cracks C. rare example of clotted microbial textures on gravel clasts, lens cap $6.7 \mathrm{~cm}$, sst., sandstone D. Lime mudstone with desiccation cracks. E. Bedding plane view of desiccation cracks in plant debris rich facies (F2) F. sand desiccation cracks G. Ripple crosslamination with lime mudstone drapes, knife $5.8 \mathrm{~cm}$ long. 
Petrography: In thin section this facies association is characterised by weakly cemented

292 massive, mixed-composition, fine-grained calcareous sandstone with variable relative percent of 293 carbonate and siliciclastic sediment $(\mathrm{b} / \mathrm{s}=1, \mathrm{~b} / \mathrm{s}<1, \mathrm{~b} / \mathrm{s}<<1 ; 50-90 \%$ siliciclastic: $10 \%-50 \%$

294 carbonate; Fig. 7E, 7F). Some interbedded carbonate-rich beds, however, have less siliciclastic 295 material $\sim 10 \%(\mathrm{~b} / \mathrm{s}>>1)$ (see white carbonate-rich beds in Fig. 7D; Fig. 8A). Carbonate grains 296 are dominated by fine-grained lime mudstone and rounded bioclasts including barnacles, 297 gastropods, and unidentifiable fine-grained carbonate sand grains likely derived from bioclastic 298 material (Fig. 7E-F). Grains are not compacted, and little to no clay or cement is present (Fig. 7E299 F).
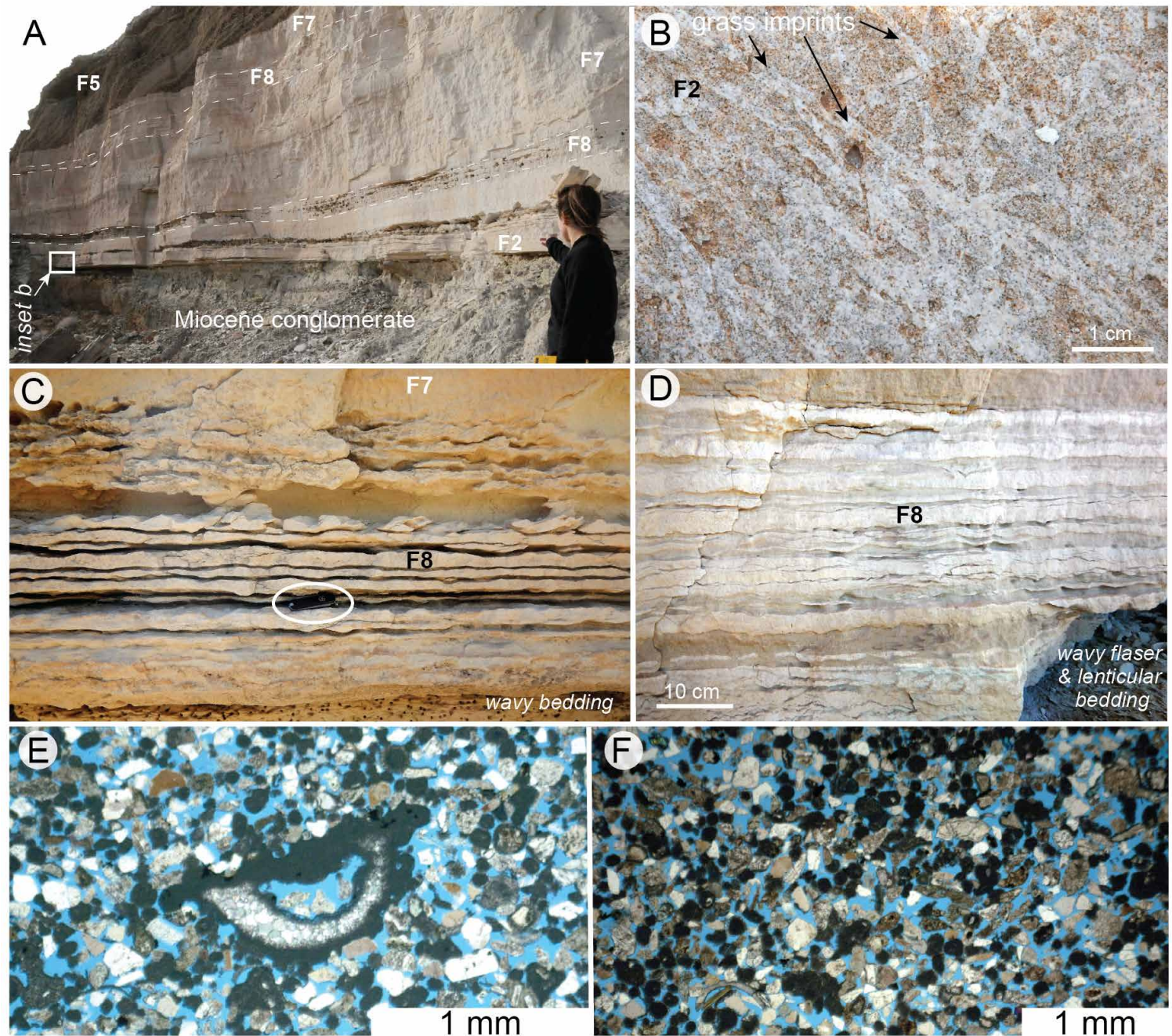

Figure 7. Facies association 1 (FA1), siliciclastic-rich tidal flats A-F. A. Undulatory plant debris rich (grasses, microbial mats, and reed casts) beds overlying Miocene conglomerate and underlying F7, F8, F5. B. Bedding plane view of matted grass(?) imprints. C. Wavy bedding, knife $3035.8 \mathrm{~cm}$ long. D. Mixed carbonate and siliciclastic wavy, flaser, and lenticular bedding; white beds 
304 relatively carbonate- rich $\mathrm{b} / \mathrm{s}>>1$; tan beds relatively siliciclastic-rich $\mathrm{b} / \mathrm{s}=1$ or $\mathrm{b} / \mathrm{s}<1 \mathrm{E}$. Thin 305 section photomicrograph shows poorly cemented calcareous sandstone with $\sim 50: 50$ carbonate and 306 siliciclastic grains. F. Thin section photomicrograph with mixed carbonate-siliciclastic grain types 307 about $\sim 20 \%$ carbonate grains.

Ichnology and palaeontology: Ichnofossils in FA1 include diminutive forms of 310 Arenicolites, Cochlichnus, Gyrolithes, Planolites, Serpulid worm tubes, Skolithos, Spirodesmos, 311 Steinichnus, possible Selenichnites, boxwork Thalassinoides (0.5-1 cm diameter), Teichichnus, 312 Treptichnus, and escape burrows associated with unidirectional ripples and parallel laminations 313 (Fig. 4, section B3; Fig. 8). In F7 and F8, Arenicolites, Cochlichnus, Steinichnus, boxwork 314 Thalassinoides (0.5-1-cm diameter), serpulid worm tubes, possible Selenichnites, Spirodesmos, 315 Teichichnus, and escape burrows associated with unidirectional ripples and parallel laminations 316 (Table 1; Fig. 4, section B3). Arenicolites, Planolites, and Skolithos occur in F9 (Table 1; Fig. 4, 317 section $\mathrm{B} 3$ ). These diminutive forms have a $<10 \mathrm{~mm}$ penetration depth and mm-scale size, low 318 trace-fossil diversities in bedding (1-2 forms), and sporadic low bioturbation indices (e.g., 319 Dashtgard \& La Croix, 2015; La Croix et al., 2015). Sandy facies (F7) in this association locally 320 preserve camel (Lamaichnium) and horse trackways (Fig. 5, section B11). 


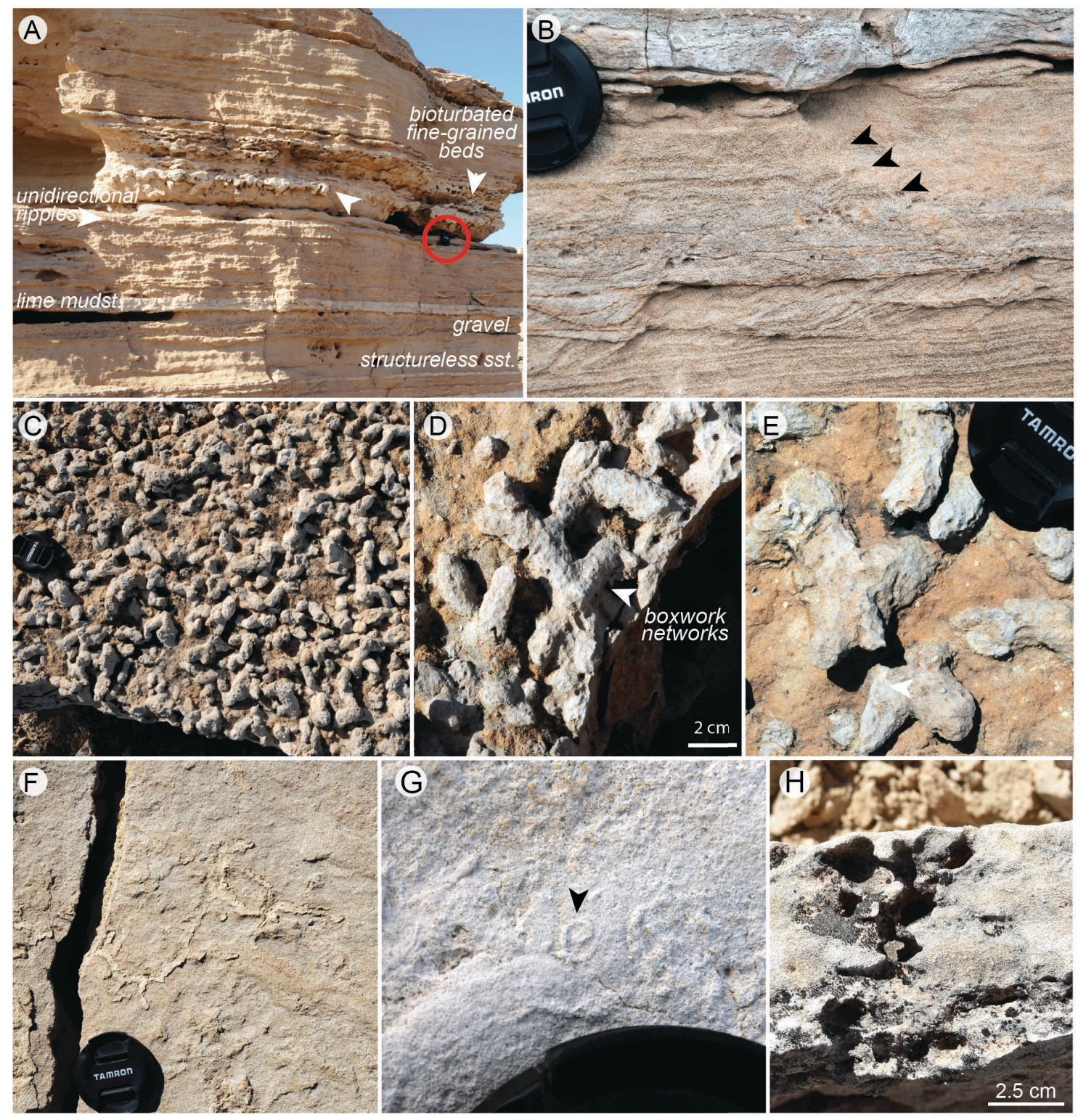

322 Figure 8. Trace fossils FA1 A. Thalassinoides bed (arrow). Note interbedding of gravels,

323 structureless calcareous sst., lime mudstone, few interbeds of relatively more carbonate-rich

324 strata (white strata, $\mathrm{b} / \mathrm{s}>>1$;). Bioturbation mainly in fine-grained beds, lens cap (circled) is 6.7

$325 \mathrm{~cm}$ (in all photos). Sst., sandstone; mudst., mudstone. B. Escape traces associated with

326 unidirectional flow ripples and parallel laminations C-E. Bedding plane view of Thalassinoides

327 bed with characteristic boxwork network; lens cap $6.7 \mathrm{~cm}$. F. Possible Serpulid worm tubes G.

328 cf. Spirodesmos. H. Possible Gyrolithes.

Interpretation: Plant debris rich facies (F2) was likely deposited by biological trapping of

334 fine-grained carbonate silt and clay by reeds and grasses in a low energy, upper intertidal to 
supratidal salt marsh environment. Deposition occurred during occasional flooding by baffling and 336 sediment entrapment in highly vegetated marshes (F2; e.g., Nyman, 1993; Dashtgard \& Gingras, 337 2005). Thin gravel interbeds (F4) may record accumulation at the base of small runoff channels or 338 tidal creeks (Dashtgard \& Gingras, 2005). Desiccation cracks (F2, F7, F9) record intermittent 339 exposure and drying of the sediment surface between flooding and depositional episodes. 340 Pervasive desiccation cracks (ubiquitous in F9) and rare raindrop imprints are common features of 341 tidal flat environments (e.g., Thompson, 1975; Hardie, 1977; Shinn, 1983). Heterolithic bedding342 -found extensively throughout this association-is a common feature of modern tidal 343 environments (e.g., Klein 1977; Dalrymple et al., 1991; Choi \& Dalrymple, 2004; Davis, 2012).

344 The tracks of camels and horses may have formed on sediment that was very shallow or subaerially 345 exposed, and likely preserved via rapid burial (Davis, 2012).

Gravels (F5) were possibly tide reworked and winnowed, as suggested by their close association with tidal deposits. The convex-up form of crossbedding in well-sorted gravel (Fig. 6A) may reflect the original convex-up geometry of barchan dune bedforms, which have been documented in high-energy gravelly tidal systems (e.g., Li et al., 2014; Todd et al., 2014). Coarsening up gravels with lenticular clinoform crossbedding (F5) may represent delta mouth bars or Gilbert deltas (e.g., Postma, 1990; Kurcinka, et al., 2018) fed by small sandy and gravelly catchments along a tectonically active basin margin (Dorsey et al., 2017).

Facies Association 1 was influenced by the interaction of fluvial freshwater and marine seawater through tidal and catchment processes. This facies association is characterised by a 355 relatively high siliciclastic component (Fig. 7, 7F) up to $8 \mathrm{~m}$ above the contact with the underlying 356 Miocene conglomerate (Fig. 5). Sedimentation in FA1 was likely periodic and episodic, with 357 heterolithic bedding typical of fluctuating tidal currents (Fig. 7C, D), bioturbated lime mudstone 358 and heterolithic facies interbedded with gravels (Fig. 6B), and high energy calcareous sandstones 359 that are structureless or contain parallel lamination and unidirectional cross lamination (Fig. 8 A, 360 B). Rapid sedimentation and deposition under nonuniform decelerating flow is indicated by the 361 presence of parallel lamination overlain by unidirectional ripples associated with escape burrows 362 (Fig. 8B). Although there is some ambiguity in determining the amount of fluvial influence on 363 sediments using physical sedimentary structures, episodic high energy currents may have occurred 364 during to river floods and intercalated finer grained bioturbated units may represent deposition 365 during interflood periods (e.g., Dalrymple et al., 2015; Kurcinka et al. 2018; Flaig et al., 2019). 
366 Despite uncertainties, one of the best tools to understand the fluvial-marine transition is the trace

367 fossil assemblage (e.g., Gingras \& MacEachern, 2012; Hasiotis et al., 2013; Flaig et al., 2019).

368 The trace fossils Gyrolithes, Selenichnites, Spirodesmos, and boxwork networks of

369 Thalassinoides are ichnogenera typical of marine environments (e.g., Häntzschel, 1975;

370 Pemberton et al., 2001; Romano \& Whyte, 2015). Ichnogenera that occur in marine, brackish, and

371 freshwater environments include Arenicolites, Cochlichnus, Conichnus, Lockeia, Planolites,

372 Skolithos, and Treptichnus (e.g., Jackson et al., 2016; Hammersburg et al., 2018; Flaig et al., 2019);

373 thus, are nondiagnostic of any one palaeoenvironment. Their co-occurrence, however, with marine

374 trace fossils suggests they represent marine organisms tolerant of freshwater influence. Low trace-

375 fossil diversities in bedding (1-3 forms) and diminutive forms with a distinct reduction in

376 penetration depth $(<10 \mathrm{~mm})$ and size (generally $\mathrm{mm}$-scale), compared to normal marine forms

377 (e.g., Gingras et al., 1999; Jackson et al., 2016), are typical of brackish-water conditions produced

378 by freshwater and marine water body interaction in tidal settings (e.g., Pemberton et al., 1982;

379 Dashtgard \& La Croix, 2015; Jackson et al., 2016; Flaig et al., 2019).

380 In sum, FA1 is interpreted as recording local interbedding of salt marsh, siliciclastic rich

381 tidal flat deposits, and nearshore gravels, consistent with tidal flats flanking a sand and gravel-rich

382 local river catchment. Only one example of evaporite pseudomorphs (after gypsum) was observed

383 during years of study in this facies association, indicating that evaporites are effectively absent.

384 The paucity of evaporites, combined with abundant desiccation cracks formed by surface exposure

385 in carbonate-rich mud flats, provides evidence for a wet humid climate during deposition (e.g.,

386 James, 1979; Rankey \& Berkeley, 2012). The implied humid conditions are unlike the hyperarid

387 modern climate of the study area, and have potential implications for understanding late Miocene

388 to early Pliocene palaeoclimate and palaeohydrology of the lower Colorado River region.

389 Facies Association 2 (FA2): Tidal-channel complex

$390 \quad$ Sedimentology: This facies association (Table 2; Figs. 9, 10, 11) includes the following 391 facies: cobble lag (F1), sandy microbial micrite (F3), crossbedded well-sorted conglomerate (F5), 392 ripple laminated calcareous sandstone (F7), and lime mudstone with desiccation cracks (F9). This 393 association is dominated by relatively siliciclastic-rich compositionally mixed (carbonate394 siliciclastic) strata. Similar to FA1, the carbonate siliciclastic ratio is most commonly $\sim 50 \%$ $395(\mathrm{~b} / \mathrm{s}=1)(\mathrm{F} 3, \mathrm{~F} 7)$, although there can be a high percentage of siliciclastic sediment in some beds of 396 F7 $(\mathrm{b} / \mathrm{s}<1)$. Lime mudstone with desiccation cracks (F9) in FA2 is considered unmixed carbonate 
397 ( $<10 \%$ siliciclastic), and other facies of this association are unmixed siliciclastics $(>90 \%$ 398 siliciclastic) (F1, F5, rare F7).

399 These facies are grouped together because they are closely interbedded and laterally 400 equivalent deposits (Figs. 9-11). Interbedded and laterally equivalent strata are encased within 401 lenticular stratal packages that are inset into a concave up erosional base (Figs 9-11). Sandy (F7) 402 and gravel (F5) deposits pass laterally (conformable relationship) into lime mudstone with 403 desiccation cracks (F9) and then sandy microbial micrite (F3) with vertebrate tracks at margins of 404 this association (Figs. 9-11). Lenticular stratal packages with an erosional base (FA2) pass 405 laterally (erosional relationship) into FA1 in the Marl Wash location (Fig. 3). Facies association 2 406 is at the same stratigraphic interval as FA1 (Fig. 2), but their relationship is unclear due to the 407 erosive contact at the base of FA2. The relationship between FA2 and FA3/FA4 is also unclear as 408 FA 2 is erosionally overlain by Quaternary gravels (Figs. 9-11).

409 Interbedded gravel and sandstone that comprise FA2 are 8-15 m thick intervals that thin 410 to $<1-\mathrm{m}$ thick by lateral transition to lime mudstone with desiccation cracks (F9) and sandy 411 microbial micrite (F3) (Figs. 9, 10). The lowest deposits of a typical inset stratal package consist 412 of thin cobble lag (F1) or thin beds of coarse conglomerate with scoured surfaces (F5) ( 0.3-2-m 413 thick) (Figs. 9 section B27; 10, 11). Gravels (F5) and sandstone (F7) commonly are overlain by 414 lime mudstone with wavy bedding (F9) or mixed siliciclastic-rich sandy inclined to horizontal 415 strata (F7) in the thicker parts of stratal packages (Figs. 9-11). Interbedded ripple laminated 416 calcareous sandstone (F7) and desiccated lime mudstone (F9) are common near the margins of 417 stratal packages, and pass laterally to sandy microbial micrite (F3) (Figs. 9-11). Some calcareous 418 sandstone (F7) is structureless, while other interbeds of F7 display trough crossbedding, parallel 419 laminations, and ripple laminations (Fig. 9). Intervals typically fine upward from gravels (F5) to 420 sands (F7) (Fig. 10 A, B) and in some cases are capped by desiccated lime mudstone (F9) or sandy 421 microbial micrite (F3) (Fig. 10 C, D; Fig. 11 A, B). At the margins of lenticular stratal packages 422 are mixed, silicified sandy microbial micrite with irregular laminations (F3) (Fig. 9-11 C-E). 


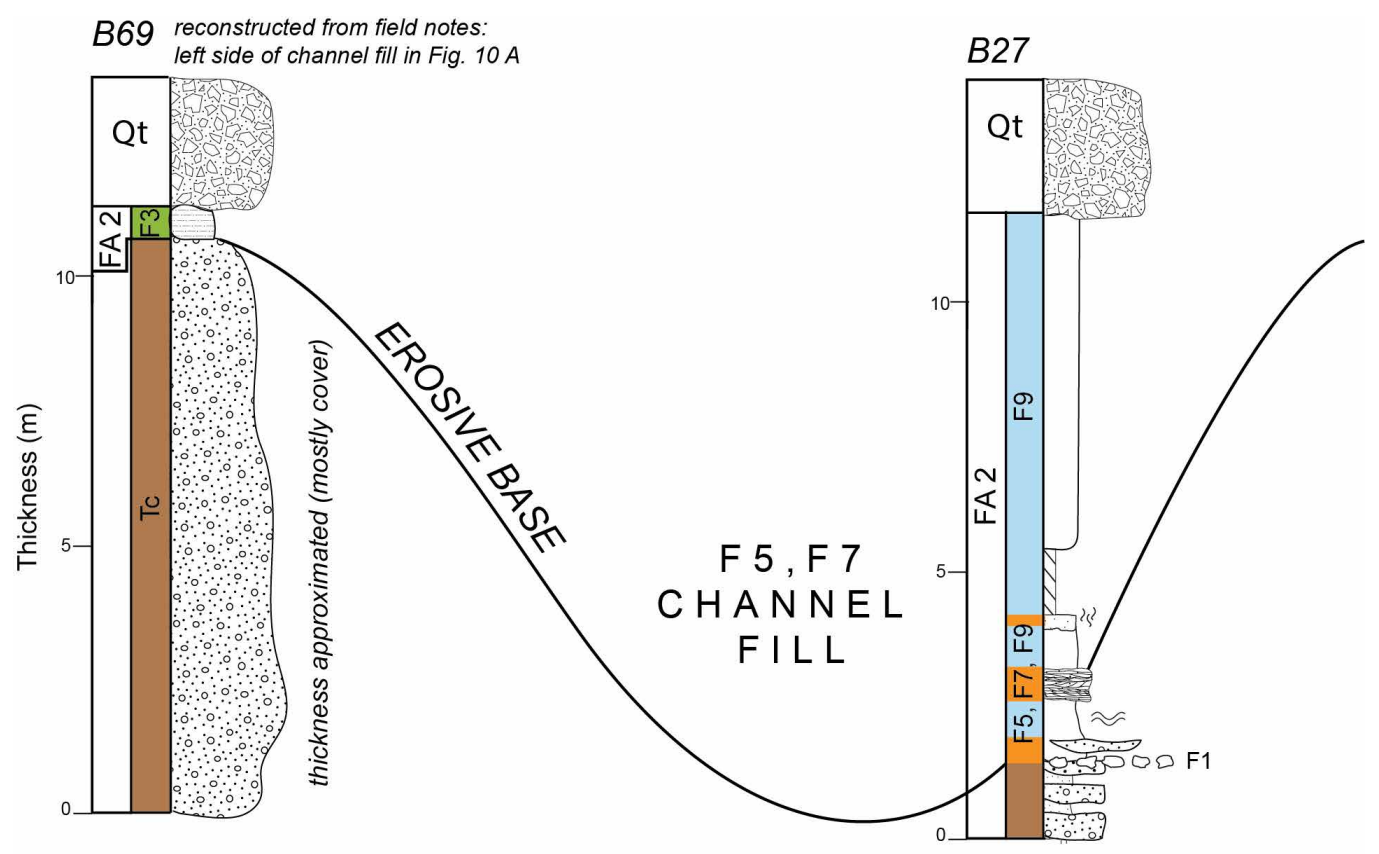

424

425 Figure 9. Facies association 2 (FA2). Section B27 was measured off mid-channel because of cliff 426 exposure (see Fig. 10). Tc, Miocene conglomerate. 

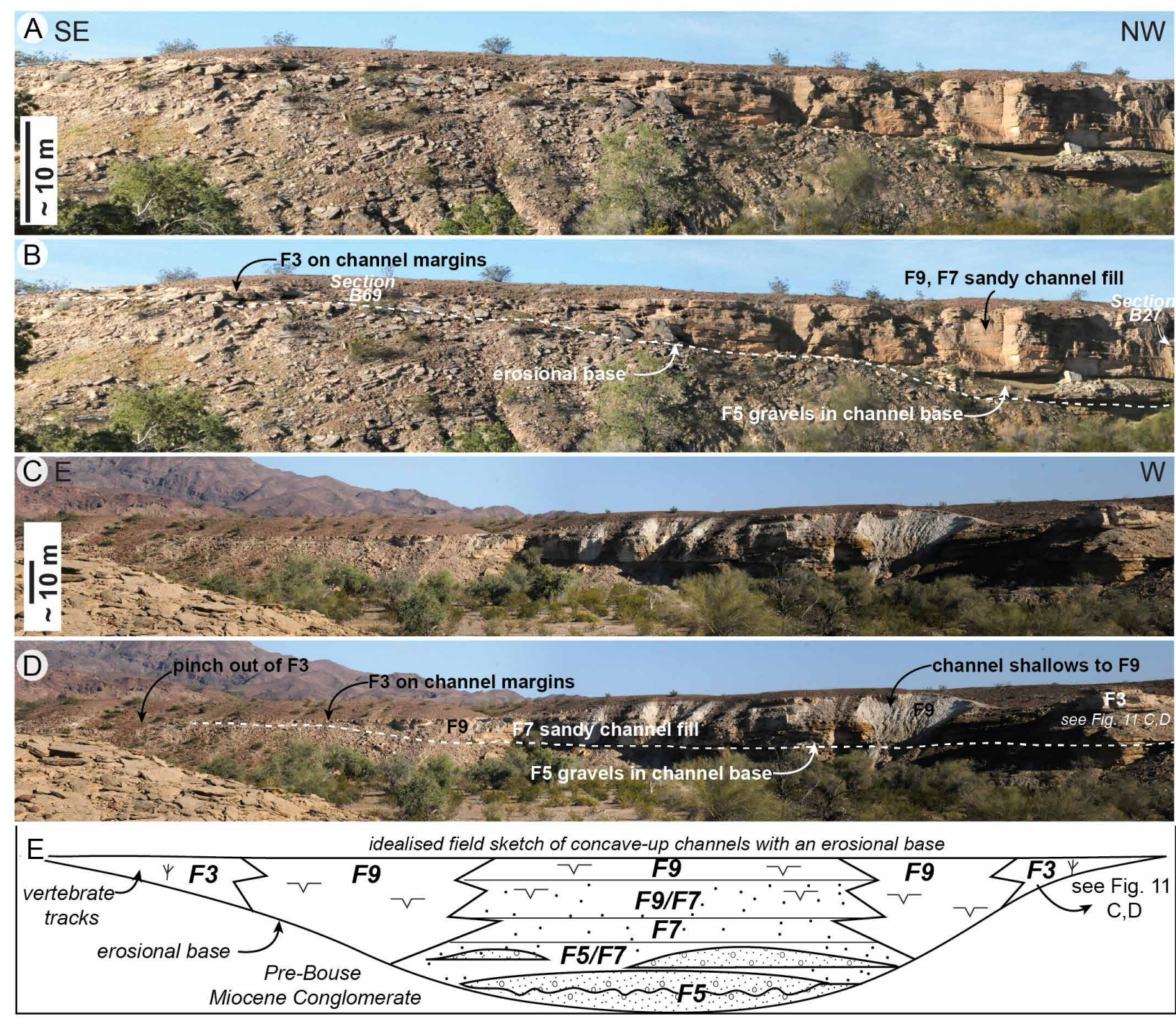

429 Figure 10. Facies Association 2 (FA2) channel-fill deposits. A. View looking SW at centre 430 and edge of a typical Bouse Formation channel-fill complex. B. Annotations highlighting main 431 features in part A; Section B27 measured out of view on right side, where outcrop was accessible. 432 C. View looking $\sim$ south at an example of a channel-fill complex. D. Annotations highlighting main 433 features in part C. Both examples show concave-up base of channel, concentration of siliciclastic 434 sand in centre of channel, onlap and thinning of deposits toward channel margins, and lateral 435 change to carbonate rich facies F9 and F3 at channel margins. E. Idealised sketch summarizing 436 main features in $\mathrm{A}-\mathrm{D}$. 


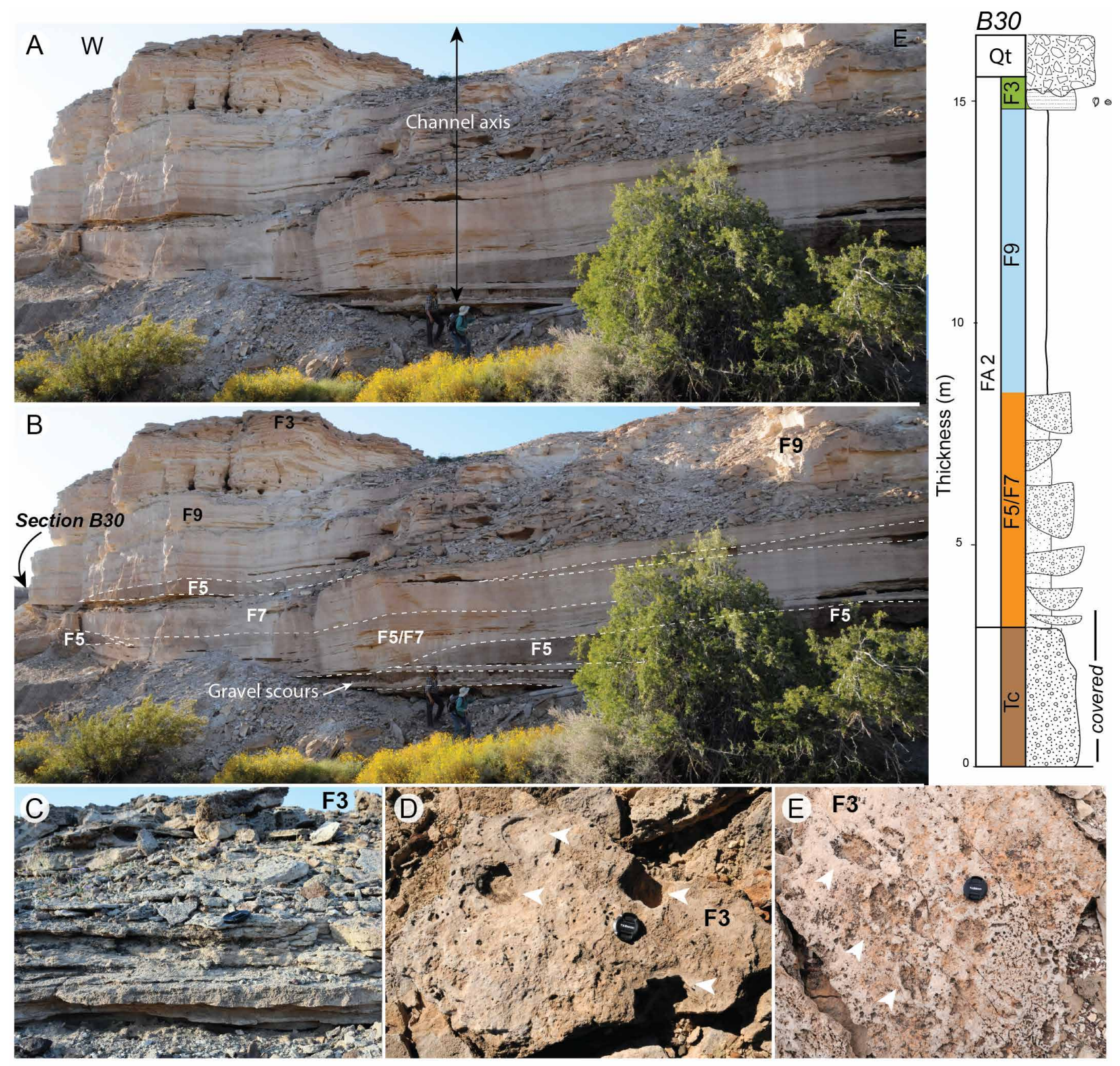

438 Figure 11. Facies association 2 (FA2). A. Photo looking at channel axis of this association. Note 439 humans for scale. Orientation of photo is looking N-NW. B. Annotated photo looking at channel 440 axis. Section B30 measured out of view on left side, where outcrop was accessible. C. 441 Representative photo of F3, found along the channel margins. Lens cap is $6.7 \mathrm{~cm}$ in all photos D. 442 Bedding plane view of horse and small elephant vertebrate tracks in F3. E. Bedding plane view of 443 camel tracks in F3. Vertebrate tracks are common in F3.

Ichnology and palaeontology: Facies three of FA2 preserves tracks of camels, small 446 elephants, felines, and horses (F3) (Fig. 11 C-E; Sarjeant et al., 2002; Sarjeant \& Reynolds 2001).

447 The vertebrate tracks are observed in mixed carbonate-siliciclastic silicified sandy microbial 
micrite (F3) at and near the margins of concave-up lenticular stratal packages. Charophytes can be rarely present in F3 (fossil ID from Metzger, 1968; McDougall and Miranda Martínez, 2014).

Interpretation: Lenticular stratal packages with an erosional base are interpreted as channel deposits that traversed a marsh and tidal flat system. Well-cemented sandy microbial micrite with vertebrate tracks record deposition in marshes along the margins of channels. Similar to FA1, sandy microbial micrite (F3) was deposited in a low energy, upper intertidal to supratidal microbial marsh environment, as is commonly observed on humid tidal flats in the modern Bahamas (e.g., Hardie, 1977; Rankey \& Berkeley, 2012). Deposition occurred during occasional flooding by baffling and sediment entrapment (e.g., Nyman, 1993; Dashtgard \& Gingras, 2005). Rare charophytes in F3 may be suggestive of brackish water, possibly similar to coastal settings with charophytes in the Baltic Sea (Steinhardt et al., 2009; Bučas et al., 2019). Lime mudstone with desiccation cracks (F9) likely records upper intertidal flat deposition along channel margins adjacent to marsh systems.

Channel fill deposits comprise variable mixtures of siliciclastic sediment derived from local river catchments and carbonate sediment produced by contemporaneous calcareous organisms (microbes, barnacles, molluscs, etc.). Some siliciclastic sediment may also be reworked from underlying Miocene alluvial fan conglomerate. Well-sorted gravels were derived from small river catchments in the Trigo Mountains and reworked into migrating gravelly bedforms that filled high-energy channels. Gravels with concave up basal scour surfaces are interpreted as channel fill deposits, similar to gravel lag deposits of fluvial bars and channels (e.g., Bridge, 1993). Cobble clast horizons at the base of channel packages at some localities (FA1; Fig. 9 section B27) may represent gravel lag deposits at the channel base. Lime mudstone with desiccation cracks (F9) is interpreted to represent tidal flat environments along channel margins that pass laterally to (F3) sandy microbial micrite. Fining- and shallowing-upward transitions from gravel-sand dominated facies to fine grained lime mudstone with desiccation cracks and sandy microbial micrite (F3) with vertebrate tracks may record lateral migration, shallowing, and filling of channels.

Other than desiccation cracks and wavy bedding in F9, FA2 contains no other obvious tidal indicators (e.g., mud drapes, flaser, lenticular bedding), in contrast with FA1. Channel orientations measure because of cliff exposures and two-dimensional (2D) representation of bedforms (Figs. $10,11)$. 
Facies Association 3 (FA3): Carbonate-rich tidal flats

Sedimentology: This facies association (Table 2; Figs. 4, 5, 12-15) includes: lime mudstone with desiccation cracks (F9), vertically laminated bedding (F10), carbonate-rich heterolithic 483 bedding (F11), barnacle and oncoid grainstone (F12), wakestone and packstone (F13), and lime mudstone and wakestone (F14). This association is characterised by relatively carbonate-rich compositionally mixed (carbonate-siliciclastic) strata. The carbonate-siliciclastic fraction is generally $\sim 70: 30(\mathrm{~b} / \mathrm{s}$ ratio $>1)(\mathrm{F} 11, \mathrm{~F} 12)$ and, in some cases, exceeds $90 \%(\mathrm{~b} / \mathrm{s}>>1)(\mathrm{F} 9, \mathrm{~F} 13$, F14).

Facies of this association are grouped together because they are closely interbedded and laterally equivalent deposits (Figs. 4, 12). Centimetre- and m-scale interbedding is common in these deposits, as are lateral facies changes over the m-scale. For example, lime mudstone with 491 desiccation cracks (F9) is commonly interbedded with carbonate-rich heterolithic bedding (F11) 492 (rare laminated F10), and crossbedded barnacle and oncoid grainstone (F12). Crossbedded 493 barnacle and oncoid grainstone (F12) also passes laterally into interbedded carbonate-rich 494 heterolithic bedding (F11) and then bioturbated lime mudstone (F14) towards the basin centre (Fig. 495 12).

496
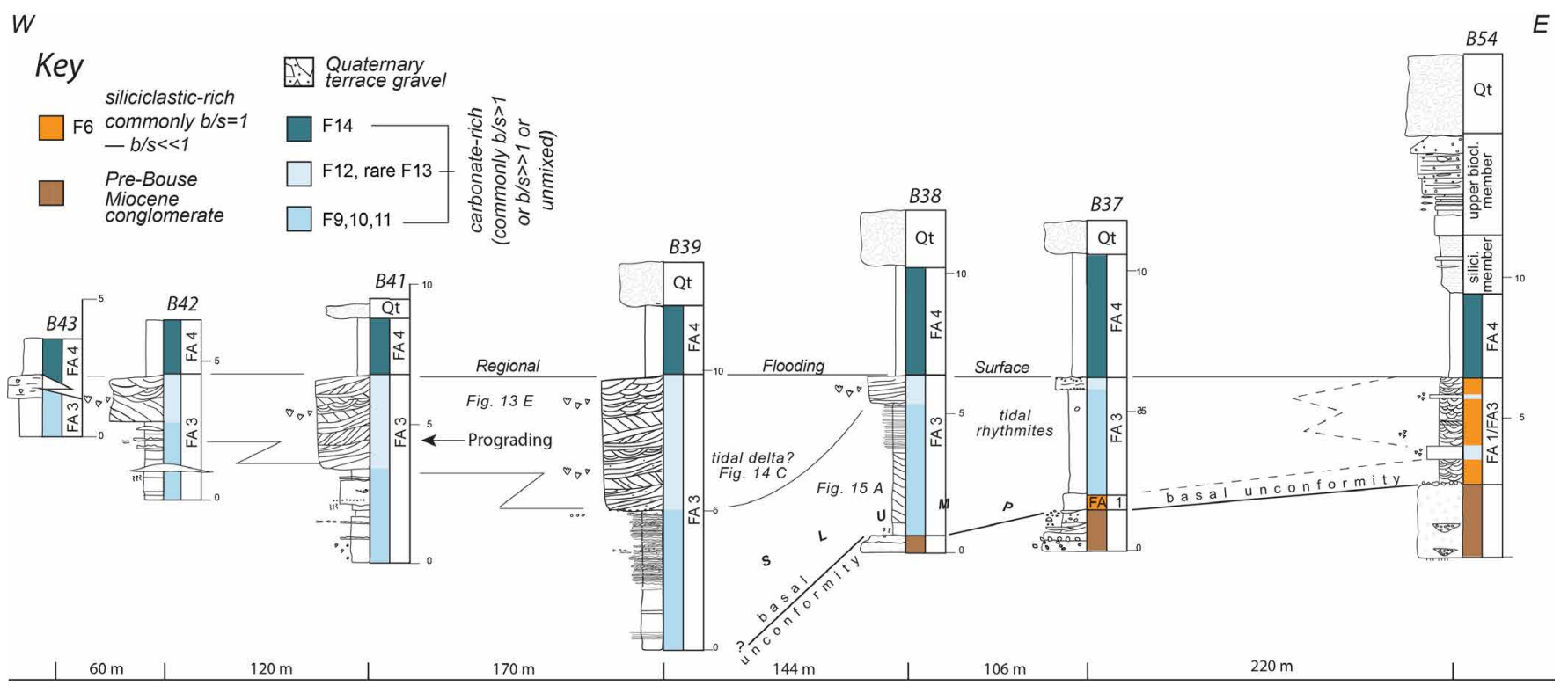

498 Figure 12. Stratigraphic sections and lateral relationships of minor FA1, FA3, FA4 from Big 499 Fault Wash. See Fig. 3 for section locations. 
501 A typical conformable vertical succession consists of an up section change from lime 502 mudstone with desiccation cracks and rare raindrop imprints (F9) to heterolithic facies (F11, rarely 503 F10) to crossbedded barnacle and oncoid grainstone (F12) (Figs. 4, 12, 13A). Lime mudstone with 504 desiccation cracks (F9) consists of unmixed carbonate micrite with desiccation cracks on most 505 bedding surfaces (Fig. 13B). Heterolithic bedded facies are mixed carbonate and siliciclastic 506 deposits that include vertically accreted planar laminated beds with rhythmic thickening and 507 thinning (F10) in association with incumbent anisodactyl bird tracks and lime mudstone with 508 desiccation cracks (F9). Vertically stacked ( 0.5- to 6-m thick) intervals of wavy, lenticular, and 509 flaser bedding (F11) are also common (Fig. 12, 13C). Barnacle- and oncoid-rich bioclastic 510 grainstone (F12) has foresets that commonly dip $\sim 30^{\circ}$, and horizontal topsets display small current 511 ripples oriented down-dip as well as obliquely to crests (Fig. 13D). Large crossbed sets are up to 5123 -m thick (but more commonly $\sim 0.3-$ to 1.10 -m thick) (Fig 12, 13E; 14A-C). 


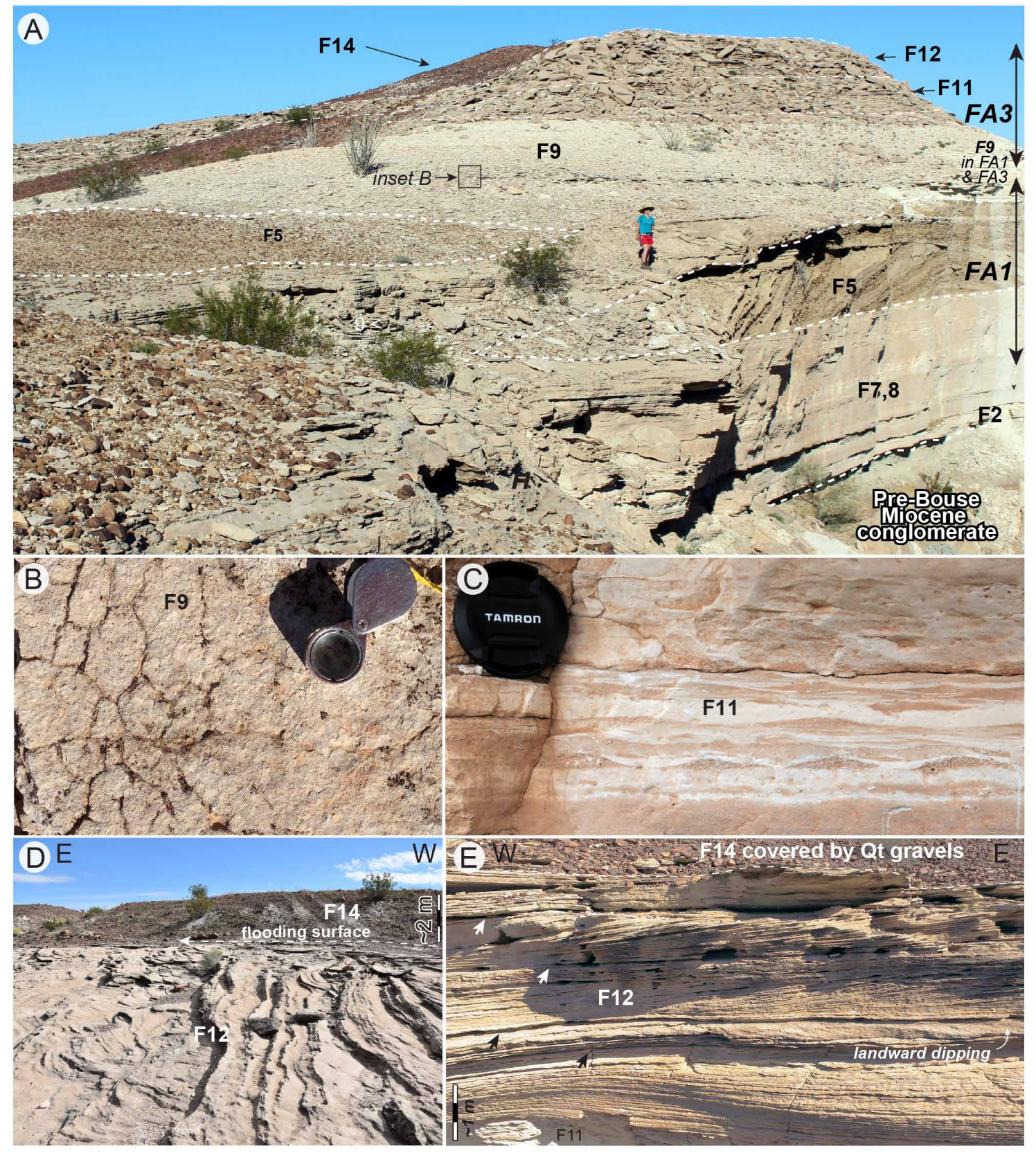

515 Figure 13. Facies association 3 (FA3) carbonate-rich tidal flats A-E: A. Representative example 516 of relationship between FA1, FA3, FA4. Orientation of photos is looking NW B. Desiccation 517 cracks on lime mudstone bedding plane surfaces C. Wavy, flaser, and lenticular bedding, lens cap 518 is $6.7 \mathrm{~cm} \mathrm{D}$. Current ripple fans oriented obliquely to foreset bedding. Note sharp contact with 519 FA4 (flooding surface). Orientation of photo is looking south C. Crossbedding with sharp set 520 boundaries indicated by arrows. Orientation of photo is looking north. 
Internal bedding in F12 is complex and includes bioclastic drapes on crossbed foresets

523 (Fig, 14 B, C), well-segregated (sensu Chiarella \& Longhitano, 2012) beds of platy-carbonate

524 bioclastic grainstone (b/s $>>1)$, and fine-grained sandy grainstone (b/s > 1) (Fig. 14B). Sigmoidal

525 bundles with rhythmic thickening and thinning of foresets are also present (Fig. 14D). Other

526 sedimentary features include locally developed soft-sediment deformation structures (in F9 and

527 F12; Fig. 14C; Fig. 15A) that are sometimes displaced along carbonate-siliciclastic boundaries

528 (Chiarella et al, 2016). Flat-topped ripples (Fig. 15B) interbedded with larger scale crossbedding

529 (0.3- to 1.10-m thick; F12) are also present. Toward the basin centre in the west, crossbedded

530 bioclastic facies (F12) pass laterally into heterolithic bedding (F11) and bioturbated lime mudstone

531 (F14) (Fig. 12; Fig. 15 C). Coarse-grained crossbedded grainstone (F12) thins and pinches out in

532 both directions, toward the basin margin and the basin centre (Fig. 12).

533 Petrography: Thin sections reveal coarse, oncoid-bioclastic grainstone with minor to

534 moderate subrounded to angular siliciclastic grains that are dominantly quartz, minor feldspar, and

535 volcanic lithic fragments (Fig. 15D-F). Bioclastic grains (of variable percent and composition)

536 include broken fragments of barnacles, gastropods, and ostracods, subspherical oncoids, and

537 unidentifiable bioclasts (Fig. 15D-F). Bivalves in some cases are completely dissolved to create

538 moulds (Fig. 15E). Mouldic porosity, or selective dissolution of bioclasts (Fig. 15E), is a common

539 feature in this facies association. Cement crusts, non-isopachous fans, and variably preserved

540 inclusion-rich, acicular carbonate cements are present (Fig. 15F). Cement fans are recrystallised

541 but, in some cases, retain mottled sweeping extinction under crossed polars. This facies can be

542 well cemented compared to FA1 and FA2 (compare cementation in Fig. 15F to Fig. 7E, F). 


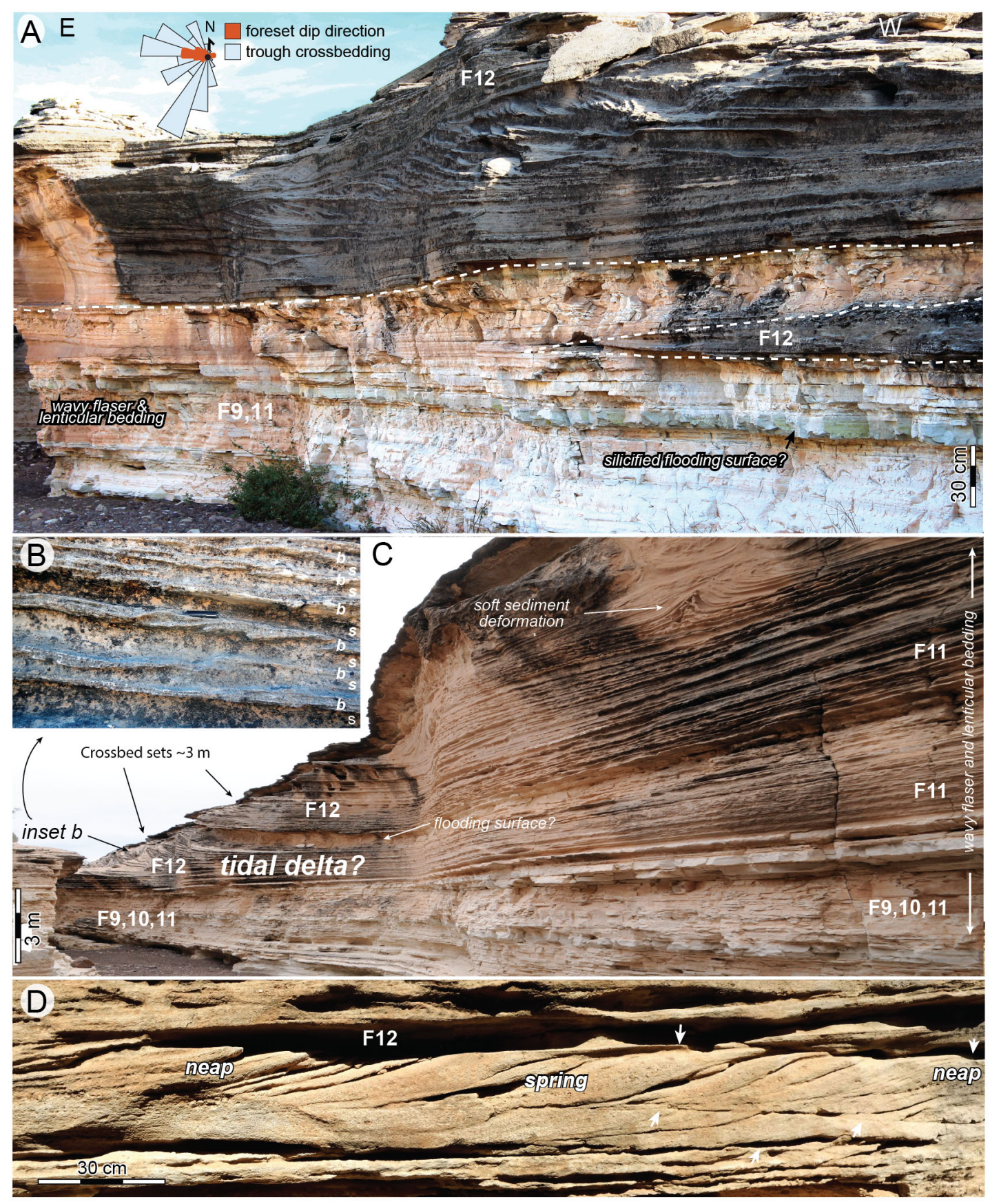

546 Figure 14. Facies association 3 (FA3) carbonate-rich tidal flats A-D: A. Barnacle and oncoid-rich 547 coarse-grained bioclastic grainstone overlying heterolithic bedding and lime mudstone with 548 desiccation cracks (F9). Orientation of photo is looking S-SE. B. Alternations of bioclastic and 549 siliciclastic sediment in crossbed foreset, knife $5.8 \mathrm{~cm}$ long. C. Coarse-grained bioclastic 550 grainstone (F12) overlying interbedded F9, 10, 11. D. Sigmoidal bundle sequence (example in 551 O'Connell et al., 2017). Arrows denote reactivation surfaces. Thin amalgamated foresets are 552 interpreted as neap tide bedforms, while thin and thick alternations of sigmoidal foresets are 553 interpreted as spring tide bedforms. 

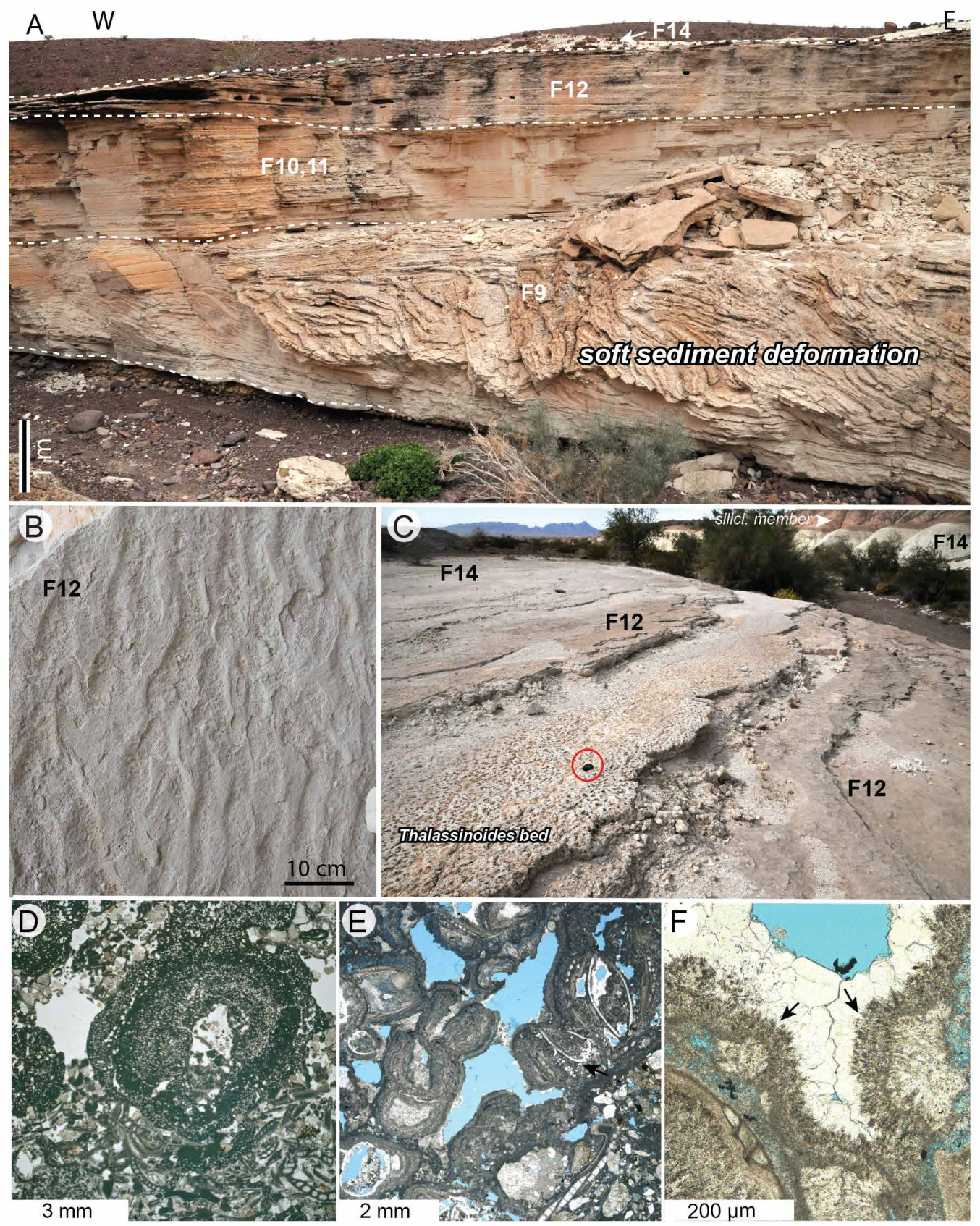

554 Figure 15. Facies Association 3 (FA3) bedforms and thin sections A-F. A. Soft-sediment 555 deformation in FA3. B. Flat-topped ripples interbedded with large bedforms in F12. C. 556 Thalassinoides bed in F12 passing laterally (basinward) to F14, note lens cap is $6.7 \mathrm{~cm}$ (circled) 557 D. Irregular laminated oncoid grains (weakly cemented). E. Bioclasts with oncoidal irregular 558 microbial laminations. Black arrow points to a selectively dissolved bioclast (mouldic porosity) F. 559 Thin, inclusion-rich cement crusts and non-isopachous fans; cement generation is succeeded by 560 clear blocky calcite cements (scalenohedral calcite). Note poor preservation of fan cement 561 (retaining sweeping extinction) suggests a former aragonitic mineralogy preserved in calcite (black 562 arrows). 
Ichnology and palaeontology: Some beds in FA3 are bioturbated by Batillaria gastropods 565 and diminutive bivalves. Trace fossils are common in heterolithic beds (mainly F11), and include 566 diminutive forms of Conichnus, Cylindrichnus, Gastrochaenolites, Planolites, Palaeophycus, 567 Skolithos, Teichichnus, and Thalassinoides (Fig. 4 Big Fault Wash composite section; Fig. 16A,B). 568 These diminutive forms generally have a $<10 \mathrm{~mm}$ penetration depth and $\mathrm{mm}$-scale size (Fig. 569 16A,B). Trace fossils in F9 include Arenicolites, Planolites Skolithos; traces in F10 include 570 incumbent anisodactyl bird tracks, < 1-mm-scale Lockia, Sagittichnus, and possible Scolicia, 571 Selenichnites, Skolithos, and Teichichnus. Trace fossils in bioclastic strata (F12) are rare, but this 572 facies can be interbedded with $\sim 10$-cm-thick, densely bioturbated beds (F14) of diminutive 573 Thalassinoides (Fig. 4 Big Fault Wash composite section; Fig. 15C). Rounded aggregates of 574 barnacle shell material up to 7-cm thick are common (Fig. 16C) In situ barnacle clusters are locally 575 present on lime mudstone with desiccation-cracked surfaces (F9), particularly where deposits are 576 interbedded and laterally adjacent to barnacle and oncoid-rich, coarse-grained bioclastic grainstone 577 (F12) (Fig. 16D). Barnacle fragments and other grains are coated extensively by coralline red algae 578 in this facies (Dorsey et al., 2018). 

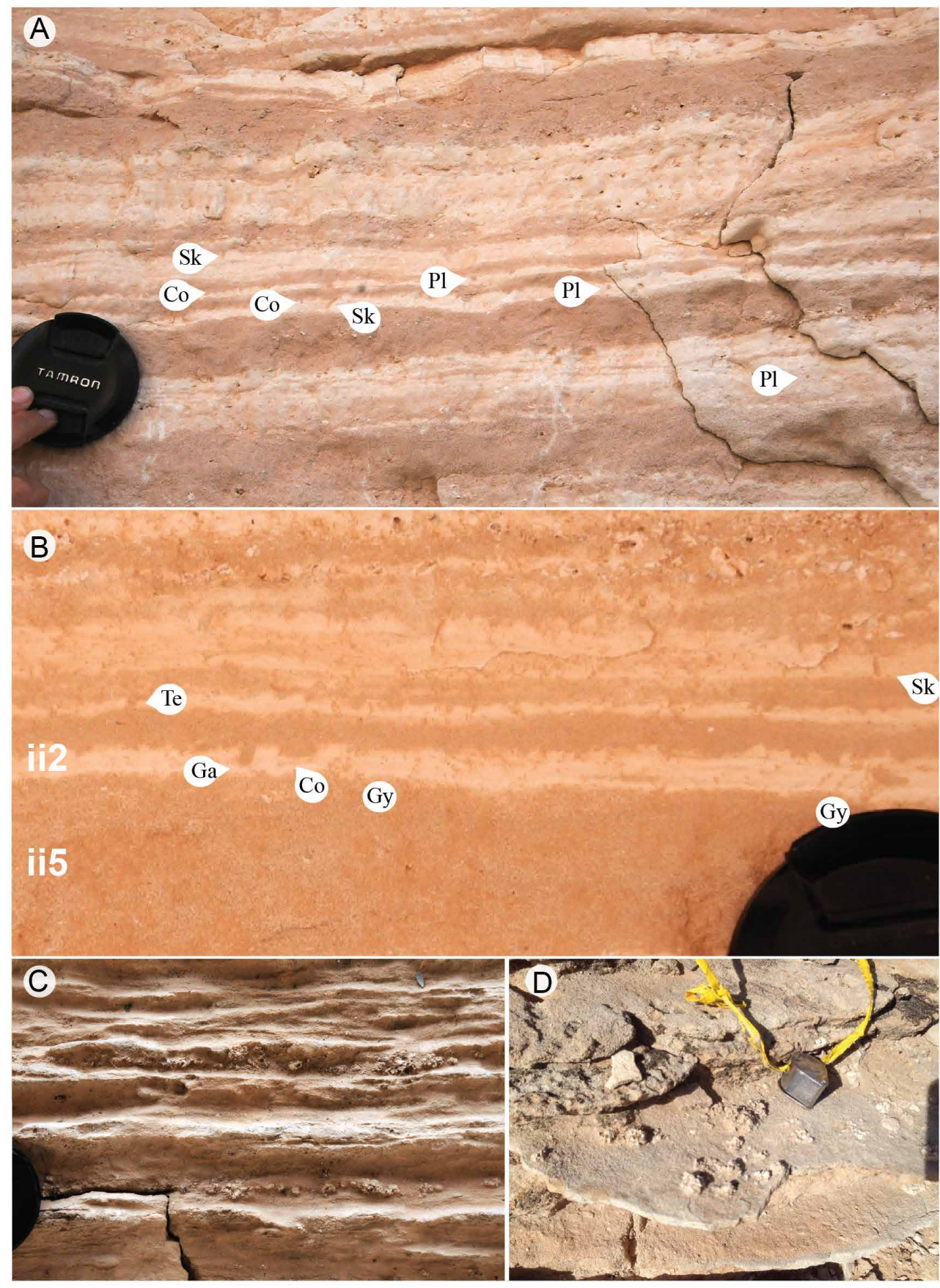

Figure. 16. Trace fossils of FA3. A, B. Diminutive traces: Gastrochaenolites (Ga), Conichnus (Co), Skolithos (Sk), Teichichnus (Te), Gyrolithes? (Gy), and Planolites (P1). Combination of

590 facies, trace fossils, and alternation of low-high ichnofabric indices (Droser \& Bottjer, 1986) are 591 typical of tidal \& marine salinity influence, lens cap is $6.7 \mathrm{~cm}$. C. Rolling barnacle aggregates, 592 lens cap is $6.7 \mathrm{~cm} \mathrm{D.} \mathrm{In} \mathrm{situ} \mathrm{barnacle} \mathrm{clusters} \mathrm{on} \mathrm{firmgrounds} \mathrm{or} \mathrm{hardgrounds} \mathrm{of} \mathrm{F9.}$ 
Interpretation: Similar to FA1, pervasive desiccation cracks and raindrop imprints in finegrained facies (F9) of FA3 record frequent exposure of mixed carbonate-siliciclastic tidal flats, a common feature of upper tidal flat environments (e.g., Klein, 1977). Heterolithic strata are interpreted to record deposition by tidal currents in intertidal to shallow subtidal environments, as evidenced by vertically stacked successions ( 0.50- to $\sim 6-\mathrm{m}$ thick) of wavy, flaser, and lenticular bedding (F11). While wavy, flaser, and lenticular bedding are rarely produced by diurnal wind patterns in dryland lacustrine environments (Ainsworth et al., 2012), stacked successions strongly suggest the action of astronomical tidal processes (Davis, 2012). Vertically accreted planar laminated beds with rhythmic thickening and thinning (F10), crossbeded foresets, and sigmoidal bundles with rhythmic thickening and thinning (F12) have been interpreted as tidal rhythmites (O'Connell et al., 2017). Tidal rhythmites are especially diagnostic of a tidal influence for this association (O'Connell et al., 2017). Vertically accreted tidal rhythmites (F10) associated with lime mudstone with desiccation cracks (F9) and incumbent anisodactyl bird tracks indicate intertidal deposition in some cases. Tidal rhythmites record rapid accumulation in environments with high production of accommodation, such as in rapidly subsiding basins (e.g., Coueffe et al., 2004). Moreover, the development of cyclic rhythmites requires high sediment supply ( 1 mm of sediment every $\sim 12$-hour period), which normally is only possible along channel margins or in delta-front settings (Dalrymple, 2010).

This facies association displays many diagnostic features that are widely used to identify

613 tidal deposits, including: (1) tidal rhythmites; (2) sigmoidal bundles and bedding; (3) high degree 614 of hydraulic sorting and segregation by grain size and composition; (4) bidirectional palaeocurrent 615 indicators; (5) landward and seaward dipping cross strata; (6) tabular bedding with sharp set 616 boundaries and complex internal cross strata; and (7) segregation between the siliciclastic and 617 carbonate fraction (e.g., Boersma \& Terwindt, 1981; Klein, 1970; Nio \& Yang, 1991; Chiarella \& 618 Longhitano, 2012; Longhitano et al., 2012a, 2012b). Coarse-grained bioclastic grainstone in FA3 619 displays a high degree of sorting and segregation (including well-segregated, sensu Chiarella \& 620 Longhitano, 2012). Such extensive sorting and segregation by grain size and composition records 621 extensive winnowing, reworking, and deposition by tidal currents (e.g., Chiarella \& Longhitano, 622 2012). Soft-sediment deformation throughout this association may be an autogenic feature caused 623 by sediment overloading in this mixed carbonate siliciclastic tidal setting (Chiarella et al., 2016). 624 Bouse synsedimentary structural tilting (Dorsey et al., 2017) may have also induced soft-sediment 
625 deformation. Tabular bedding is typical of tidal dunes and tidal crossbedding, possibly because 626 currents are not strong enough to produce 3D dunes, or regularly reversing currents prevent 2D 627 bedforms from evolving to 3D bedforms (Dalrymple \& Rhodes, 1995; Rubin, 2012).

628 This study proposes that at the majority of FA3 is intertidal based on interbedded lime 629 mudstone with desiccation cracks (F9), heterolithic bedding (F10), and crossbedded grainstones 630 interbedded with flat-topped ripples (F12). Intertidal barnacle- and oncoid-rich grainstone 631 bedforms likely pass laterally (basinward) into shallow subtidal barnacle- and oncoid-rich 632 grainstone bedforms (F12). The most basinward facies of this association is bioturbated lime 633 mudstone and wakestone (F14). Facies 14 is interpreted to represent more distal shallow subtidal 634 equivalents of intertidal and shallow subtidal barnacle- and oncoid-rich grainstone (F12).

635 Occasional bioturbated beds (F14) interbedded with (F12) may record periods of relative quiescence and colonization by marine infaunal organisms, likely during neap tides (Tape et al., 637 2003; Longhitano and Nemec, 2005) or incipient flooding events during marine transgression. 638 Barnacle aggregates or balanuliths (in F11 and F12) - free-living clusters of marine barnacles that 639 nucleate around shell fragments (Fig. 16C) —resemble mobile hardgrounds described by Cadée 640 (2007) in the North Sea. Barnacle shell material in FA3 likely was sourced from in situ barnacle 641 clusters produced on firmgrounds or hardgrounds on lime mudstone tidal flats (F9) (Fig. 16D). 642 The presence of balanuliths is significant as these spherical aggregations are produced by 643 continuous movement along on the sediment surface (Cadée, 2007).

644 The trace fossils Cylindrichnus, Teichichnus, and boxwork networks of Thalassinoides are 645 ichnogenera typical of marine environments (e.g., Häntzschel, 1975; Bromley, 1996; Pemberton 646 et al., 2001; Hasiotis et al., 2013; Flaig et al., 2019). Diminutive forms of Conichnus, 647 Cylindrichnus, Gastrochaenolites, Planolites, Palaeophycus, Skolithos, Teichichnus, and 648 Thalassinoides, with a distinct reduction in penetration depth $(<10 \mathrm{~mm})$ and size (generally $\mathrm{mm}-$ 649 scale), compared to normal marine forms (Gingras et al. 1999), are typical of brackish-water 650 conditions produced by freshwater and marine water body interaction in intertidal settings (e.g., 651 Pemberton et al., 1982; Dashtgard \& La Croix, 2015; Jackson et al., 2016; Flaig et al., 2019).

652 The poorly preserved, inclusion-rich non-isopachous crusts and fans in calcite (Fig. 15F) 653 suggest replacement of an unstable primary mineralogy, likely aragonite or possibly high-Mg 654 calcite marine cement (e.g., Alexandersson, 1972; Folk, 1974). Abundant, former aragonite or 655 high-Mg calcite fibrous cements are best explained by cementation in a shallow to nearshore 
656 marine environment, where precipitation from high-Mg pore waters commonly results from fluid 657 pumping and/or degassing (e.g., Folk, 1974; Flügel, 2004). This is consistent with other 658 observations that support a marine environment for the Bouse Formation (O'Connell et al., 2017; 659 Dorsey et al., 2018; Garnder \& Dorsey, in press; this study). High porosity, strong fluid flow, or 660 long exposure on the seafloor may have contributed to a higher degree of cementation in this facies association compared with FA1 and FA2.

\section{Facies Association 4 (FA4): Subtidal Lime mudstone and wackestone}

Sedimentology: This facies association (Table 2; Fig. 17) includes the lime mudstone and wakestone facies (F14) and is characterised by carbonate-rich strata (unmixed or b/s $>>1$; sensu Chiarella \& Longhitano, 2012). This facies association only includes F14 because F14 is not interbedded with, or laterally equivalent to other facies in this FA. Facies 14 of FA4 sharply overlies mixed tidal deposits of FA3 (Fig. 12).

This association includes interbedded recessive carbonate, thin beds $(3-10 \mathrm{~cm})$ of very thinly laminated (1-3-mm thick) micrite, and resistant thin massive beds of white lime mudstone (F14; Table 1; Fig. 17). Carbonate deposits are typically massive (Fig. 17A, B), though near the 672 basin centre can be locally cyclic over $\sim 50$-cm-thick bedding intervals (F14; Fig. 17C). Close to 673 basin margins, where basin subsidence was limited (Dorsey et al., 2018), the top of FA4 includes $674 \sim 0.4-1$-m-deep networks of sharp margin, branching $\mathrm{V}$ shaped, irregular sand-filled cavities that 675 cut the lime mudstone and wackestone host rock (F14; Fig. 17D, E). Breccia fill in such networks 676 is composed of fine- to medium-grained grainstone, siliciclastic quartz sand, and locally derived 677 sediment (Fig. 17D, E; Dorsey et al., 2018).

Petrography: Facies association 4 is composed of laminated or massive structureless lime micrite with minor clay and quartz silt (Fig. 17 F, G). Some samples show rhythmic $\sim 1$-mm-scale carbonate laminae grading up to silicified laminae (Fig. 17G).

Ichnology and palaeontology: Facies association 4 includes laminated lime mudstone that lacks bioturbation (Fig. 17G) and bioturbated massive lime mudstone (Fig. 17H). Bivalves, fish fossils, snails, foraminifera, and ostracods are common in bioturbated beds of FA4 (Fig. 17H; McDougall \& Miranda-Martínez, 2014; Bright et al., 2016, 2018; Dorsey et al., 2018), whereas fauna are sparse in thinly laminated carbonate micrite. Trace fossils and fossils in bioturbated beds 
687 impressions, possible Paleodictyon, and Planolites (Fig. 4, Big Fault Wash composite section).

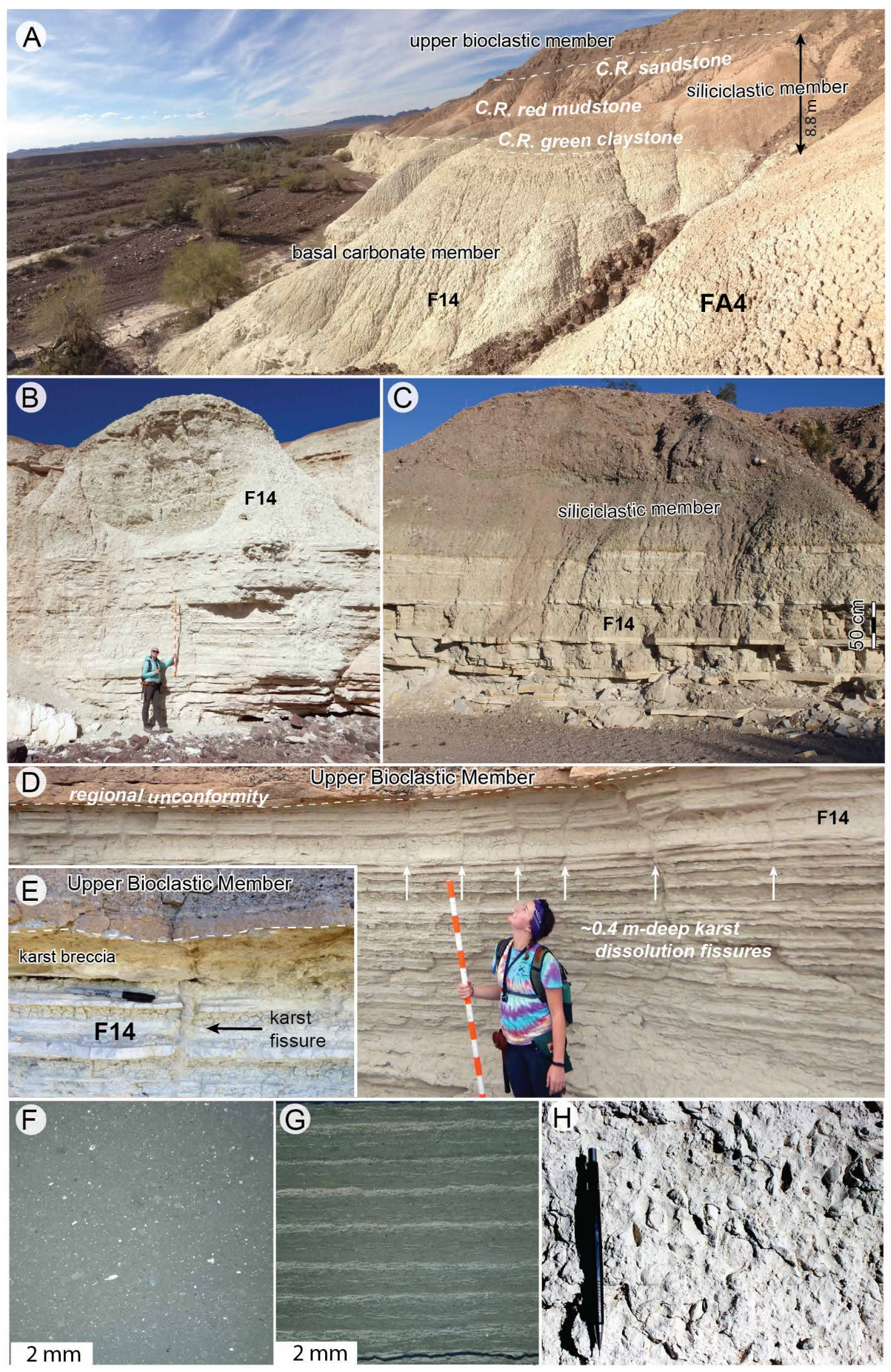

Figure 17. Facies association 4 (FA4) Lime mudstone and wackestone, A-H: A. Lime mudstone (FA4), siliciclastic member of Bouse Formation (Colorado River deltaic deposits), and upper bioclastic member (Dorsey et al., 2018). Orientation of photo is looking W-NW. B. Massive and 
Karst fissures at basin margin (Dorsey et al., 2018). F. Micrite and clay. Massive matrix with dispersed quartz silt and opaque irregular fragments, possibly organic matter. G. Laminated micrite and clay with somewhat graded microcrystalline silica replacement. White laminae are a microcrystalline silica precipitate, dark laminae are micrite and clay laminae (nontidal). $\mathrm{H}$. Bedding plane view of bivalves.

Interpretation: Facies association 4 is inferred to have accumulated in 10- to $100-\mathrm{m}$ water depth based the foraminiferal assemblage presented in Dorsey et al. (2018). These water depth estimates are consistent with the abundance of lime mudstone sediment in FA4 that indicates a low-energy environment protected from waves and currents (shallow to deep subtidal or lagoonal; Sanders \& Höfling, 2000). Some exposures of this facies association possibly represent lagoonal environments, but its position as the most exposed distal basinward deposit and the lack of evidence for an offshore barrier system lead us to interpret most of FA4 as a low-energy shallow to deep subtidal deposit. There is no evidence for a tidal influence in FA4, as previously noted (O'Connell, 2016; Dorsey et al., 2018). Intervals of bioturbation are consistent with deposition in a subtidal environment with a relatively low sedimentation rate (e.g., Rubin \& Friedman, 1977; Overstreet et al., 2003). Interbedded, thinly laminated, unbioturbated units provide evidence for occasional anoxia or suboxic conditions, or rapid deposition (such as whiting events) and burial such that beds remained undisturbed prior to burial.

Intervals of alternating resistant (laminated) and non-resistant (massive) lime mudstones (Fig. 17C) may represent climate-driven cycles or occasional development of anoxic conditions (no bioturbation). Rhythmic $\sim 1$-mm-scale laminations may represent small, cyclic changes in sedimentation or seawater chemistry. Silicification is likely a marine feature, perhaps associated with a lack of detrital input (low sedimentation) and more prolonged exposure to seawater in a low-energy environment, though a secondary diagenetic origin for the silica cannot be ruled out. Networks of $\sim 0.4-1$-m-deep, sharp margin, irregular sand-filled cavities are interpreted as basinmargin karst features. Palaeokarst features at the unconformable upper surface of FA4 record subaerial exposure and dissolution due to regional lowering of relative sea level that exposed subtidal marine strata to a humid climate before deposition of the overlying upper bioclastic member (Fig, 17D,E; e.g., Meng et al., 1997; Booler \& Tucker, 2002; Dorsey et al, 2018). Karstification must have occurred post deposition of FA4, but pre deposition of the overlying Bouse upper bioclastic member (Fig. 17D, E). 


\section{Ichnology Interpretation}

Trace fossils documented in this study are typical of continental, freshwater, brackish, and marine environments (Hasiotis, 2002; MacEachern et al., 2007; Gingras et al., 2012; Hasiotis et al., 2013; Figs. 8, 11, 16). Marine traces include diminutive forms of Gyrolithes, Teichichnus, and boxwork networks of Thalassinoides. Facies-crossing traces-forms that can occur in marine, brackish, or freshwater environments-include Arenicolites, Cochlichnus, Conichnus, Lockeia, Planolites, Skolithos, and Treptichnus (Fig. 8; Fig. 16). These diminutive trace-fossil forms have a distinct reduction in penetration depth $(<10 \mathrm{~mm})$ and size (generally mm-scale), compared to normal marine forms (e.g., Gingras \& MacEachern, 2012; Jackson et al., 2016; Flaig et al., 2019). In sandy facies (F7) and in channel margin sandy microbial micrite (F3), continental trace fossils include Celliforma, Steinichnus, and vertebrate tracks and trackways produced by horses (Fig. 11D), proboscideans (i.e., elephant; Fig. 11D), and artiodactyls (i.e., camel; Fig. 11E) (Sarjeant \& Reynolds 2001; Sarjeant et al., 2002; Hasiotis, 2002). Heterolithic bedded, intertidal to shallow subtidal deposits (F11) include diminutive Conichnus, Cylindrichnus, Gastrochaenolites, Palaeophycus, Planolites, Skolithos, Teichichnus, and Thalassinoides (Fig. 16A, B). Deeper water subtidal deposits include intercalated bioturbated and unbioturbated lime mudstone beds (FA4), and appear to be dominated by such horizontal forms as Planolites, Lockeia, and possible Paleodictyon. Lime mudstone upper tidal flats (F9) and intertidal and shallow subtidal tidal flats

744 (F7-8; F12) are weakly bioturbated, bedded, and highly heterogeneous. In some cases, very low trace-fossil diversities in bedding (1-2 forms) as well as sporadic low bioturbation indices suggest deposition in the freshwater reaches or highly variable brackish portions of this mixed system, common in tidal settings with freshwater influence (e.g., Dashtgard \& La Croix, 2015; La Croix et al., 2015; Flaig et al., 2019). Bioturbated beds are generally fine grained and generally do not appear to represent intervals of high sedimentation (e.g., Fig. 8A); thus, ichnofossil associations likely reflect the ambient conditions in the basin. High sedimentation rates and/or alternating high velocity currents may have also hindered bioturbation (e.g., Gingras et al., 1999; Hasiotis et al., 2013; Flaig et al., 2019).

Marine traces documented in this study are similar to marine intertidal assemblages

754 characterised by mixed co-occurring horizontal and vertical traces including Arenicolites, 755 Palaeophycus, Planolites, Skolithos, Teichichnus, and Thalassinoides (Gingras \& MacEachern, 756 2012). Overall, a diminutive marine fauna and low-diversity assemblage suggest salinity stress 
757 (e.g., Pemberton, 1982; Pemberton \& Wightman, 1992; Gingras et. al., 1999; Hauck et al., 2009; 758 Jackson et al., 2016; Flaig et al., 2019). Marine infauna tolerant of brackish-water settings are 759 generally characterised by trophic-generalist behaviours, many of which are facies crossing

760 because of dynamic depositional conditions and variability in food resource availability and forms.

761 They typically include Arenicolites, Cylindrichnus, Palaeophycus, Planolites, Skolithos, 762 Teichichnus, and Thalassinoides (Pemberton \& Wightman, 1992; Gingras et al., 2012), which are 763 similar to ichnofauna documented here. The suite of brackish tolerant marine ichnofauna 764 documented in this study is consistent with the sedimentology of the Bouse Formation, which 765 records a setting where local fluvial catchments provided siliciclastic sediment and freshwater to 766 the margins of a marine tidal strait.

\section{DISCUSSION}

\section{Depositional Model}

The Bouse Formation basal carbonate in the study area was deposited at the low gradient eastern margin of a marine tidal strait at the north end of the ca. 6 Ma palaeo-Gulf of California (Fig. 18A). New results from exposures south of the Palo Verde Mountains indicate that the tidal strait ran through the Highway 78 pass, connecting the palaeo Gulf of California to the Bouse inland sea (Fig. 18A; Garnder \& Dorsey, in press), consistent with results of other recent studies (e.g., O’Connell et al., 2017; Dorsey et al., 2018; Garnder \& Dorsey, in press). The Bouse inland sea is inferred from marine foraminiferal fauna found as far north as Parker, AZ (McDougall \& Miranda-Martinez, 2014) and Bouse Formation beach and tidal flat deposits at Amboy, CA (Miller et al., 2014) (Fig. 18A). Tidal currents played a major role in the distribution and accumulation of mixed-carbonate siliciclastic facies in this system. Evidence for tidal deposition and associated subaerial exposure is indicated by pervasive desiccation cracks (mainly F9, F2, F7), flat-topped ripples (F12), rain drop impressions (F9), stacked wavy, flaser, and lenticular bedding (F8, F11), tidal rhythmites (F10, F12), sigmoidal bedding (F12), and extensive sorting and segregation by grain size and composition (F8, F7, F11, F12; e.g., Chiarella \& Longhitano, 2012). On the east

785 side of the basin (the focus of this study), palaeocurrents recorded in large crossbed forests (F12) 786 are generally directed to the west, with a minor component to the east (Figs. 4, 13D-E, 14A, 18B). 787 Palaeocurrents measured in trough crossbedding superimposed on larger scale crossbed foresets 

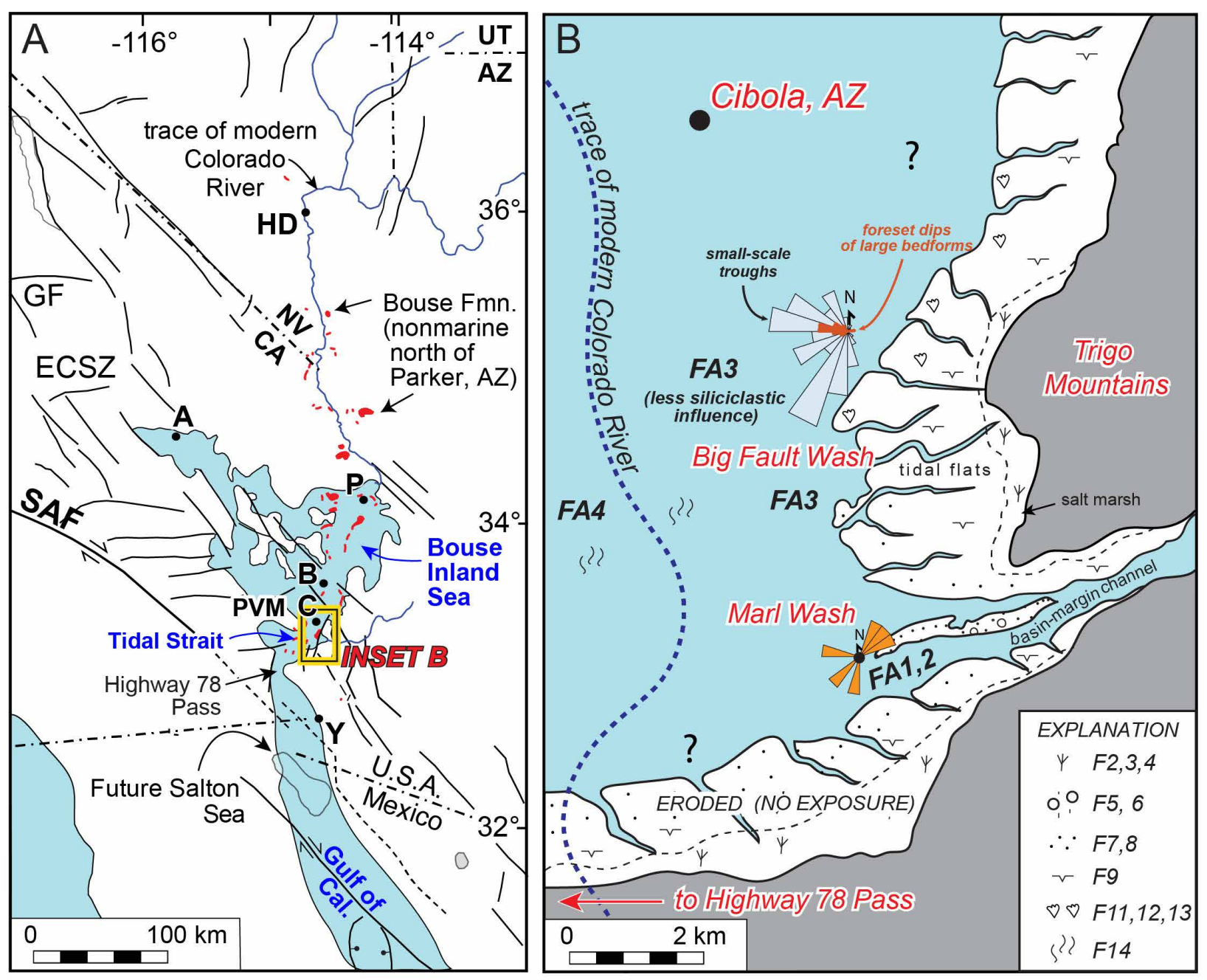

Figure 18. A. Reconstruction of the northern Gulf of California, tidal strait, and Bouse inland sea during deposition of the basal carbonate member ca. $6 \mathrm{Ma}$, prior to first arrival of the Colorado River (modified from Dorsey et al., 2018). Red patches represent modern exposures of the Bouse Formation. Note the segmented narrow connection (tidal strait; Garnder \& Dorsey, in press) that connected the Gulf of California in the south to the Bouse inland sea in the north. This study documents the eastern facies at the margins of the tidal strait (inset B). B. Depositional model for the Bouse basal carbonate member southeast of Cibola, Ariz. (this study). Abbreviations: A, Amboy; B, Blythe, Calif.; C, Cibola, Ariz.; ECSZ, Eastern California Shear Zone; GF, Garlock fault; P, Parker, Ariz.; PVM, Palo Verde Mountains; SAF, San Andreas fault; Y, Yuma. 
The depositional model developed for these deposits (Fig. 18B) depicts reconstructed subenvironments interpreted from detailed facies analysis. Major palaeoenvironments include siliciclastic-rich intertidal tidal flats (FA1), siliciclastic-rich channel networks (FA2), carbonaterich intertidal and shallow subtidal flats (FA3), and shallow-deep subtidal lime mudstone (FA4).

808 Initial deposition was dominated by siliciclastic-rich tidal flats and channel networks (FA1 and FA2) that formed above a basal unconformity produced by inundation and reworking of preexisting alluvial fans at the eastern margin of an encroaching marine transgression (Dorsey et al., 2018). Carbonate sediment was produced in situ by coralline red algae, barnacles, and molluscs that were then reworked by tidal currents and hydraulically mixed with siliciclastic sand and gravel

813 derived from local river channels in the Marl Wash area (Fig. 3, 18B). The Big Fault Wash area, 814 which was located farther from the source of siliciclastic input, accumulated mostly carbonate-rich tidal flat deposits (FA3) with only minor siliciclastic-rich facies (FA1).

Facies relationships documented in this study show that FA3 accumulated in areas removed from siliciclastic input, whereas siliciclastic-rich FA1 and FA2 formed closer to local sources of sand and gravel (Fig. 18B). Contemporaneous deposition of FA1 and FA3 is supported by data from Big Fault Wash, where FA1 trough-crossbedded sandstone (F6) passes laterally west into carbonate-rich tidal flat deposits (Fig. 12). In Marl Wash, facies associations display an overall up-section change from FA1 siliciclastic-rich (generally $\mathrm{b} / \mathrm{s}=1$ or $\mathrm{b} / \mathrm{s}<1$ ) compositionally mixed carbonate-siliciclastic sediment to FA3 relatively carbonate-rich (b/s $>1$ and $>>1)$ compositionally mixed deposits (Figs. 4, 5). The observed up section change from FA1 to FA3 in Marl Wash, where all facies associations are present (Figs. 4, 5), may record landward migration of distal carbonate-rich facies (FA3) over more proximal siliciclastic-rich facies (FA1). This landward shift of facies belts resulted from the same transgression that initiated tidal deposition in the study area, drowning the mouths of local rivers and trapping siliciclastic sediment progressively farther upstream in basin flanking river catchments. The lack of evaporites in FA1 and FA3, presence of diminutive, brackish-water tolerant marine trace fossils, and karstification of FA4 (post deposition of FA4 but pre deposition of the upper bioclastic member), all suggest deposition in a relatively wet and humid climate throughout Bouse Formation deposition (see section on implications for 832 palaeoclimate).

Deposition of FA3 was terminated by increased water depths and an abrupt shift to widespread deposition of subtidal lime mudstone (FA4). The abrupt contact of FA3 with subtidal 
835 lime mudstone (FA4) (Fig. 12) is a flooding surface that represents the culmination of a long lived 836 rise in relative sea level due to tectonically driven regional subsidence (Dorsey et al., 2018).

837 On the west side of the southern Blythe basin, sedimentary facies of Bouse Formation basal 838 carbonate in the Palo Verde Mountains (Fig. 1C; Garnder \& Dorsey, in press) display similarities 839 and differences to those observed on the east side of the basin southeast of Cibola, AZ (this study; 840 Fig 18). Similar to deposits near Cibola, facies in the Palo Verde Mountains display a transition 841 from siliciclastic-rich to carbonate-rich bioclastic deposits that record tidally influenced 842 sedimentation during marine transgression and deepening through time. In contrast, basal 843 carbonate facies in the Palo Verde Mountains accumulated on a structurally active, steep basin 844 margin on the flanks of local bedrock highs and alluvial fans, and transgressive fan fringing tidal 845 flat deposits are overlain by crossbedded subtidal bioclastic compound dunes and carbonate sand sheets (Garnder \& Dorsey, in press). The basal carbonate member of Bouse Formation in the Marl

847 Wash area (this study) preserves a different suite of facies because it did not form near local steep 848 topography, and instead records shallow marine inundation of a low-gradient surface. This resulted 849 in development of a broad tidal-flat system with abundant tidal channels that traversed a much 850 wider and shallower, lower-gradient tidal strait margin than documented in the southeastern Palo 851 Verde Mountains. The contrasting facies associations and depositional gradients of eastern and 852 western margins of the tidal strait reflect structurally controlled differences in palaeotopography 853 and cross-valley basin asymmetry (Garnder \& Dorsey, in press).

854 In sum, the margins of this tidal strait hosted a large variety of depositional processes and 855 environments. On the west side of the basin (PVM) these environments included alluvial fans, 856 mixed carbonate-siliciclastic fan fringing intertidal flats, and an extensive subtidal compound dune 857 complex (Garnder \& Dorsey, in press). On the east side of the basin (this study), environments 858 included a broad belt of low-gradient salt marsh, channels, and intertidal tidal flats - both 859 siliciclastic rich (FA1) and carbonate rich (FA3). The observed local abundance of siliciclastic 860 sediment near the base of the basal carbonate member (FA1, FA2) and suite of brackish tolerant 861 marine ichnofauna (FA1 and FA3), provides evidence for a local fluvial catchment that delivered 862 siliciclastic sediment and freshwater to the east margin of the marine tidal strait, see below.

\section{Features of the Bouse Depositional System}

865 Siliciclastic production and evidence for freshwater-seawater mixing 
Brackish water composition due to mixing of freshwater and seawater along the margins

867 of the tidal strait is supported by evidence from sedimentology, ichnology, palaeontology, and 868 stable isotopes, including: (1) diminutive trace fossils compared to typical marine forms (Figs. 8, 869 16); (2) low to very low trace-fossil diversity in bedding (1-2 forms) and sporadic low bioturbation 870 indices (this study; e.g., La Croix et al., 2015; Dashtgard \& La Croix, 2015; Jackson et al., 2016);

871 (3) low diversity and high abundance of brackish-water tolerant diminutive marine fauna (Metzger, 872 1968; Smith, 1970; McDougall \& Miranda-Martinez, 2014); (4) abundance of barnacles with 873 distinctive thin plates (Zullo \& Buising, 1989); (5) low oxygen isotope values in Bouse 874 microfossils ( $\sim-10 \delta^{18} \mathrm{O}$; Bright et al., 2016); and (6) positive covariation of oxygen and carbon 875 isotopes trending to zero in Bouse Formation carbonates in the study area (Roskowski et al., 2010; 876 Crossey et al., 2015). These data all point to significant salinity stresses due to mixing of freshwater 877 and marine water, and require significant input of freshwater along the margins of the tidal strait. 878 The siliciclastic-rich composition of facies in FA1 and FA2, combined with multiple lines 879 of evidence for salinity stress, indicate that local rivers delivered sediment and water from river 880 catchments in the Trigo Mountains (Fig. 1C) to the margins of the tidal strait. Some siliciclastic 881 sediment in FA1 and FA2 was likely reworked from underlying Miocene alluvial-fan 882 conglomerate, but that cannot explain the presence of siliciclastic-rich deposits up to $8 \mathrm{~m}$ above 883 the contact with the older Miocene conglomerate (Figs. 4, 5). Siliciclastic sediment in these 884 deposits are dominated by locally abundant metamorphic and volcanic rock types, deposited before 885 the arrival of Colorado River-derived sediment (Fig. 2; Dorsey et al., 2018). The Bouse Formation basal carbonate member in the studied area, therefore, accumulated before the arrival and 887 integration of the Colorado River to the Gulf of California, which requires freshwater input from 888 local rivers to produce the brackish-water composition and resulting environmental conditions documented in this study.

The abundance of carbonate in this mixed carbonate-siliciclastic marine tidal system can 891 be reconciled with the inference of significant freshwater mixing with seawater during deposition. 892 The underlying, bedrock-encrusting freshwater tufa that comprise the oldest unit of the basal 893 carbonate member of the Bouse Formation accumulated in a carbonate-oversaturated system fed 894 by deeply sourced groundwater and carbonate-oversaturated freshwater (Crossey et al., 2015). 895 Since mixed bioclastic units of this study directly and conformably overlie the basal freshwater 896 tufa (Fig. 2), the mixed bioclastic-siliciclastic deposits also are inferred to have formed in a 
897 carbonate-oversaturated system that favoured in situ deposition of organic and inorganic 898 carbonate. Carbonate oversaturation may explain the abundance of carbonate sediment in a 899 brackish-water system, although the controls on water chemistry of this ancient tidal system are

900 not well understood. It is also possible that carbonate material was precipitated in shallow marine 901 subtidal settings and transported shoreward to intertidal flats (Ginsburg, 1971).

902

\section{Carbonate production}

904 The carbonate assemblage is also an important factor in mixed carbonate-siliciclastic 905 sedimentation. The Bouse Formation represents a mixed carbonate-siliciclastic system with a 906 predominant heterozoan assemblage (co-occurrence of molluscs, barnacles and coralline algae; 907 sensu James, 1997; James and Lukasik, 2010; Michel et al., 2018). This assemblage is similar to 908 well documented heterozoan assemblages in modern and Pliocene Gulf of California deposits (e.g., 909 Foster et al., 1997; Halfar et al., 2004, 2006); the lack of echinoderms and bryozoans in Bouse 910 carbonates likely reflects brackish water conditions created by freshwater input (see above). 911 Despite tectonically induced fluctuations in base level, siliciclastic input, and tidal versus nontidal 912 deposition, carbonate deposition was never completely switched off during deposition of the basal

913 carbonate member. The most siliciclastic-rich beds at the base of this unit — where fluvial input of 914 siliciclastic sedimentation was likely strongest-contain a significant proportion of carbonate 915 grains (commonly $\sim 50 \%$ ). A setting where siliciclastic input dilutes but never shuts down 916 carbonate production is similar to the open coast setting described by Zeller et al. (2015), where 917 the heterozoan assemblage continued to produce carbonate under high siliciclastic input and the 918 proportion of grains varies as a function of siliciclastic dilution of carbonate sediment. Similar 919 mixed carbonate-siliciclastic deposits have also been described from microtidal heterozoan 920 skeletal carbonates in the Mediterranean (Longhitano et al., 2011; Chiarella et al., 2012).

\section{High lateral facies variability at bedform, outcrop, and basin scales}

923 Heterogeneity is pronounced within bedforms of the Bouse Formation in the study area.

924 For example, foreset bedding on tidal dunes displays rhythmic alternation of siliciclastic- and 925 carbonate-rich sediments (O’Connell et al., 2017; Fig. 14B, C). Tidal currents contributed to 926 mixing, hydraulic sorting, and segregation of carbonate and siliciclastic grains, perhaps as a result 927 of grain segregation over small superimposed bedforms. These results are consistent with tide 
928 induced heterogeneity of facies and bedding described in Mediterranean settings by Longhitano 929 (2011). Outcrop and bedform scale heterogeneities observed in the basal carbonate member of the 930 Bouse Formation are similar to bed scale compositional mixing in basin-margin facies from a 931 variety of mixed localities reviewed in Chiarella et al. (2017). Pronounced lateral transitions in 932 facies are also observed at the outcrop scale. For example, siliciclastic conglomerates pass laterally 933 into fine-grained, siliciclastic-rich mixed calcareous sandstone to lime mudstone with desiccation 934 cracks over < $200 \mathrm{~m}$ (FA1; Fig. 5). In FA2, sandy channel fill (F5, F7) passes laterally into channel 935 margin sandy microbial micrite facies (F3) over 100-200 m (Fig. 9-11). In FA3, crossbedded fine936 grained grainstone (F12) passes laterally into heterolithic bedding (F11) over 100-200 m (Fig. 12; 937 Fig 14C).

938 In addition to variability at the bedform and outcrop scale, Bouse Formation basal 939 carbonate displays pronounced basin scale variability. A variety of mixed carbonate-siliciclastic 940 facies and subenvironments co-existed in the Blythe Basin (Fig. 1) with high variability of facies 941 and carbonate percentages along strike of the palaeoshoreline. Along strike of the palaeoshoreline $942 \sim 1-2-\mathrm{km}$ north, facies at the base of the section are dominated by carbonate-rich tidal flat deposits 943 (FA3) (Figs. 12, 18). Across the basin in the southeast Palo Verde Mountains ( 7 km away) at the 944 same stratigraphic interval, Bouse basal carbonate deposits include alluvial fan sheet flood and 945 debris-flow gravels interbedded with fine-grained mixed carbonate-siliciclastic deposits of fan 946 fringing tidal flats, overlain by high energy bioclastic subtidal compound dunes (Garnder \& 947 Dorsey, in press). The variety of facies associations from time-equivalent strata highlights 948 variations in siliciclastic input, depositional gradient, energy, and palaeoenvironments that 949 developed along the margins of this carbonate-siliciclastic tidal strait (Fig. 18).

950 Spatial patterns summarized here are similar to carbonate-rich tidal flats adjacent to 951 siliciclastic-rich tidal flats documented in Spain by Bádenas et al. (2018). Schwartz et al. (2018) 952 also found a wide array of contemporaneous mixed carbonate-siliciclastic environments in the 953 Neuquén Basin of Argentina, and postulated that the variety and complexity of mixed carbonate954 siliciclastic settings are related to both the proportion of carbonate and siliciclastic production, and 955 such dominant marine transport processes as storm, shelf, and tidal currents. Similar local 956 variability has also been documented from the Pleistocene Apennines (Italy), where four coastal 957 wedges show variable stacking patterns and variable mixed carbonate-siliciclastic ratios just 2$958 \mathrm{~km}$ apart from each other, interpreted to result from variable sediment supply and local syn- 
959 depositional tectonics that controlled differential subsidence and uplift (Chiarella et al., 2019).

960 Synsedimentary structural tilting controlled the stratigraphic architecture of the Bouse Formation

961 (Dorsey et al., 2017) and may have also exerted an influence on the distribution of siliciclastic-

962 rich versus carbonate-rich facies (Chiarella et al., 2019).

Sedimentary Hydrodynamics

965 During intervals of tidal deposition (FA1-FA3), strong currents in this tidal system 966 contributed to mixing of carbonate and siliciclastic sediment. Data suggest that mixing of 967 carbonate-siliciclastic grains was best developed during transgression due to rising relative sea 968 level (see Dorsey et al., 2018, for sequence stratigraphic interpretation). Zeller et al. (2015) 969 proposed a similar process in which the transport of siliciclastics was strongest during transgressive phases, allowing for enhanced transport of siliciclastic grains via an along-shelf

971 current system that was most active during times of rising relative sea level in the Neuquén Basin

972 of Argentina. Results from the basal member of the Bouse Formation in the southern exposures 973 along the Colorado River (this study) suggest that sustained transport and reworking by tidal 974 currents was the main process responsible for thorough mixing of carbonate and siliciclastic grains. 975 The model of tidal mixing — along the margins of a geographically restricted tidal strait (Fig. 18) 976 -is similar to the tidal mixing model of Bádenas et al. (2018) in the Mesozoic Galve Sub-basin, 977 Spain, though the sediments deposited in the open coast tidal setting of that study were more 978 influenced by storms and waves than the sediments of the Bouse Formation.

\section{Evolution of the Bouse system}

The abrupt transition to lime mudstone and wackestone (FA4), which lacks tidal features, 984 al., 2016). Intertidal conditions possibly continued around the retreating margins of the basin as 985 the basin deepened (e.g., Longhitano et al., 2014). Alternatively, it is possible that hydrodynamics 986 changed due to a rise in relative sea level and the basin fell out of tidal resonance as it passed out 987 of the tidal-amplification window (e.g., Pugh, 1987; Sztano \& De Boer, 1995). Recent studies 988 show that this regional marine transgression took place during a period of negligible to slow 989 eustatic sea level fall, which requires subsidence in a tectonic lowland at the north end of the Gulf 
990 of California to produce deepening of marine waters through time (Dorsey et al., 2018; Umhoefer 991 et al., 2018). The tidal deposits of the Bouse Formation are now exposed at 100-300 m above sea

992 level, requiring post-Miocene uplift of this basin to modern elevations in the lower Colorado River 993 corridor (O’Connell et al., 2017; Garnder \& Dorsey, in press).

994 The Bouse Formation basal carbonate member in the study area records local episodes of 995 shallowing due to aggradation and progradation of tidal deposits against the backdrop of regional 996 marine transgression. For example, gravel and sandy beds in tidal channel systems (FA2) display 997 shallowing upwards into desiccated lime mudstone (Fig. 10C, D, 11A, B), and siliciclastic-rich 998 tidal flats shallow up section from sandy lower and mixed tidal flats to upper tidal flat desiccated 999 lime mudstone (Figs. 4, 5). Tidal bedforms also overlie possible incipient flooding surfaces (Fig. 1000 14A, C) stratigraphically beneath the abrupt and widespread transition to shallow to deep lime 1001 mudstones (Fig. 4; FA4). Observed shallowing-up intervals represent exceptions to an overall 1002 basin wide regional deepening up progression from intertidal (FA1) to intertidal and shallow 1003 subtidal (FA3) to subtidal (FA4) sedimentary deposits (Homan, 2014; Dorsey et al., 2018). 1004 Deepening of tide-influenced deposits, as recorded in the abrupt transition to subtidal facies 1005 association FA4, occurred when vertical aggradation of tidal sediments was outpaced by 1006 subsidence and associated rise in relative sea level. Above the FA3-FA4 contact, input of 1007 siliciclastic sediment from nearby river catchments was nearly completely shut off and effectively 1008 removed as a component of this depositional system (FA4), highlighting the important control of 1009 relative sea level on mixed carbonate-siliciclastic sedimentation (cf. Van Siclen, 1958; Wilson, 1010 1967).

1011

1012

Implications for late Miocene-early Pliocene palaeoclimate

1014 Deposits of wide channel belts (FA2) with sandy microbial micrite supratidal facies (F3) 1015 in the Bouse Formation strongly resemble non-evaporative deposits typical of modern humid tidal 1016 flats in Andros Island, Bahamas (e.g., Rankey \& Berkeley, 2012). Indeed, the concentration of salt 1017 marsh deposits (with possible microbial mats) in these settings (F1-3 in FA1 and FA2), the lack 1018 of evaporites, and common occurrence of channel deposits (FA2) are characteristic of the 'humid 1019 channelled belt' tidal flat morphotype defined in these settings (e.g. James, 1979; Shinn, 1983; 1020 Wright, 1984). In contrast to humid tidal flat deposits represented by FA1 and FA2 of this study, 
1021 the present-day northern Gulf of California is a hyperarid sabkha tidal flat system with rainfall of 1022 only 50-100 mm/year (Thompson, 1975; Ezcurra \& Rodriguez, 1986). The modern northern Gulf 1023 of California is an evaporative macrotidal basin where evaporation rates of $\sim 2.0-2.5 \mathrm{~m} /$ year 1024 produce enhanced salinities of 35-37 per mil in coastal areas (Bray, 1988; Lavín et al., 1998; Lavín 1025 \& Marinone, 2003; Norris, 2010). In this setting, supratidal and intertidal flats are characterised 1026 by extensive halite and gypsum precipitation in distinct layers and as intrasediment crystals 1027 (Thompson, 1975; Castens-Seidell, 1984; Castens-Seidell \& Hardie, 1984). Thompson (1975) 1028 described much of the modern northern Gulf sediment as 'barren mudflats and salt flats' where 1029 gypsum and halite make up significant constituents of the mud. Mud laminae are commonly 1030 deformed and ruptured due to extensive evaporitic crystallization, forming chaotic clay-evaporite 1031 mixtures (Thompson, 1975). Salt marshes in the northern Gulf of California are characterised as 1032 sabkha arid marshes (e.g., Morzaria-Luna et al., 2014; Kearney \& Fagherazzi, 2016), with both 1033 unvegetated and mixed (vegetated and non-vegetated) banks, abundant evaporites, and weak soils 1034 produced by dissolution and recrystallization of salts (Thompson et al., 1975; Glenn et al., 2006). While tidal cyclicity in the late Miocene to early Pliocene Bouse marine setting may have 1036 been similar to that of the modern Gulf of California (O’Connell et al., 2017), considerable 1037 differences exist between modern and ancient styles of sedimentation. Sediment in the modern 1038 Gulf of California tidal flats is mainly sourced from the Colorado River and reworked by tides 1039 (Thompson, 1975), whereas sediments of the basal carbonate member of the Bouse Formation 1040 accumulated before arrival of Colorado River sediment. The Bouse Formation basal carbonate in 1041 the study area lacks evaporites and contains no indicators of evaporite dissolution (i.e., solution 1042 collapse breccias), whereas the modern Gulf of California is characterised by an abundance of 1043 evaporites with deformed and ruptured beds (Thompson, 1975; Castens-Seidell, 1984; Castens1044 Seidell \& Hardie, 1984; Glenn et al., 2006). Similar differences are observed between modern tidal 1045 systems in contrasting climate regimes, such as the well-studied arid sabkha flats in the Persian 1046 Gulf versus humid tidal flat and channel systems in the Bahamas. The arid Persian Gulf, with $<100$ $1047 \mathrm{~mm} / \mathrm{yr}$ rainfall, hosts abundant gypsum and anhydrite evaporites (Purser, 1973; Lokier et al., 1048 2013), while in the humid Bahamas (>1200 mm/yr rainfall), evaporites are ephemeral or absent 1049 (Shinn \& Ginsburg, 1964; James, 1979; Shinn, 1983; Wright, 1984; Rankey \& Berkeley, 2012). 1050 Multiple lines of evidence summarized earlier indicate that conditions during deposition of 1051 the upper Miocene to lower Pliocene Bouse Formation in the study area were considerably wetter 
1052 than the present day arid climate of the southwestern U.S. and northwest Mexico. This finding is 1053 consistent with studies that document a humid climate with widespread lakes in the western and 1054 southwestern U.S. during Pliocene time (Thompson, 1991; Forrester, 1991; Thompson \& Fleming, 1055 1996; Remeika et al., 1998). Comparison of modern El Niño events to late Miocene-early Pliocene 1056 palaeoclimates (Molnar \& Crane, 2007), global compilations of palaeovegetation and climate 1057 patterns (Salzmann et al., 2011; Winnick et al 2013), and hydrologic modelling of palaeolakes 1058 (Ibarra et al., 2018) all indicate that the late Miocene to early Pliocene climate in the southwestern 1059 USA was significantly wetter than today. In the Lake Mead region east of Las Vegas, Nevada, 1060 USA, increasing freshwater inflow to a network of late Miocene playa lakes caused the lakes to 1061 become progressively larger, fresher, and more interconnected, resulting in a change through time 1062 from evaporite accumulation in small depocenters to widespread deposition of freshwater 1063 lacustrine carbonates by ca 5.6 Ma (Crossey et al., 2015; Faulds et al., 2016).

1064 Chapin (2008) suggested that tectonic opening of the Gulf of California caused increased 1065 advection of water vapor to the southwestern U.S. and intensification of the North American 1066 monsoon by $\sim 6 \mathrm{Ma}$, resulting in increased precipitation and lake overflows that drove downward

1067 integration of the Colorado River. The late Miocene transition from smaller evaporite basins to 1068 larger lakes with freshwater limestones in the Lake Mead region (Faulds et al., 2016) is consistent 1069 with this idea, though the ubiquitous occurrence of Pliocene wet conditions throughout the western 1070 U.S. (Winnick et al., 2013) suggests that Pliocene moisture was not sourced solely from southerly 1071 monsoonal flow. Low stable isotopes that display linear covariation along a trend to seawater 1072 values (Roskowski et al., 2010; Crossey et al., 2015) in tidally influenced carbonates that predate 1073 arrival of the Colorado River (Dorsey et al., 2018; this study) point to input of freshwater from 1074 local rivers that may have been fed by strong monsoonal precipitation, though the relative 1075 contribution of monsoonal vs. continentally derived river waters is unknown.

\section{Implications for mixed carbonate-siliciclastic tidal deposits}

1078 Improved models for ancient mixed carbonate-siliciclastic sedimentation require an 1079 understanding of the processes that control carbonate deposition, siliciclastic input, and mixing of 1080 grain types. These processes extend beyond the singular control of base level, and include other 1081 important factors such as carbonate assemblage, climate, tectonic setting, and modes of sediment 1082 transport (e.g., Tcherepanov et al., 2008; Zeller et al., 2015; Chiarella et al., 2019). The Bouse 
1083 Formation is a well-exposed example of an ancient mixed carbonate-siliciclastic tidal setting 1084 where the carbonate assemblage, basin geometry, tidal cyclicity, and tectonic setting are relatively 1085 well constrained by prior studies and modern processes in the nearby Gulf of California. For 1086 example, the basal carbonate member of the Bouse Formation may have had a tidal cyclicity 1087 similar to the modern northern Gulf of California (O'Connell et al., 2017). In the Bouse setting, 1088 fault-controlled tectonic subsidence produced a rise in relative sea level at the northern most end 1089 of the palaeo-Gulf of California (Dorsey et al., 2018). Syndepositional faulting and structural 1090 tilting during deposition of the Bouse Formation (Dorsey et al., 2017) may have also influenced 1091 the mixed carbonate-siliciclastic composition and stacking of sedimentary packages over short 1092 distances between Marl Wash and Big Fault Wash (Figs. 3, 18; similar to Chiarella et al., 2019). 1093 These deposits likely accumulated in a wet and humid climate, in contrast to the hyperarid climate 1094 of the modern Gulf of California. High rates of siliciclastic input to the carbonate-producing basin 1095 were likely influenced by the tectonically active setting and high annual precipitation.

1096 The Bouse Formation has heterogeneity at the bedform, outcrop, and basin scale. 1097 Understanding bed- and outcrop-scale heterogeneities is important for hydrocarbon exploration 1098 because mixed facies are common and are characterised by strong contrasts in permeability and 1099 porosity that may influence flow migration and reservoir evolution (e.g., McNeill et al., 2004; 1100 Ainsworth, 2010; Chiarella et al., 2017). For example, studies of the Delaware Basin (USA) show 1101 that a significant portion of hydrocarbon production comes from mixed carbonate-siliciclastic 1102 seafloor fans that differ significantly from their pure siliciclastic equivalents (Kvale et al., 2019).

1103 The high lateral facies variability documented in this study at the basin, outcrop, and bedform scale 1104 indicate that future study of this and similar mixed carbonate-siliciclastic settings is needed for 1105 improved facies models and understanding of mixed tidal hydrocarbon reservoirs.

\section{CONCLUSIONS}

1107 Integrated sedimentologic, stratigraphic, petrographic, and ichnologic data from the basal 1108 carbonate member of the Bouse Formation in the southern Blythe basin provide a record of 1109 deposition at the margin of a marine tidal strait near the north end of the late Miocene to Pliocene 1110 Gulf of California. These deposits comprise 14 facies and four facies associations that accumulated 1111 before arrival of siliciclastic sediment from the Colorado River. Trace fossils are indicative of 1112 terrestrial, freshwater, brackish, and marine palaeoenvironments, consistent with sedimentological 1113 interpretations. The main conclusions and implications of this study are summarized below: 
1114 1. This study documents depositional processes and sedimentary environments at the margin 1115 of a transgressive tidal strait near the north end of the $\sim 6$-Ma Gulf of California.

11162 . This study proposes that relatively siliciclastic-rich heterolithic sediment, siliciclastic 1117 gravels and sands, and lime mudstone with desiccation cracks accumulated in tidal flat 1118 deposits with a fluvial influence (FA1). Lenticular stratal packages with concave up 1119 erosional bases (FA2) are interpreted as tidal-channel deposits. Relatively carbonate-rich 1120 heterolithic sediment, lime mudstone with desiccation cracks, and crossbedded bioclastic 1121 grainstone (FA3) accumulated in carbonate-rich intertidal to shallow subtidal 1122 environments. Finally, lime mudstone (FA4) accumulated in low energy shallow to deep 1123 subtidal settings.

1124 3. An abrupt stratigraphic transition from tidal deposits (FA3) to low energy subtidal lime 1125 mudstone (FA4) represents a widespread flooding surface associated with a regional rise 1126 in relative sea level. Relative sea level rise resulted from tectonically controlled subsidence 1127 in the late Miocene to early Pliocene northern Gulf of California.

1128 4. Evidence from palaeontology, ichnology, and sedimentology provides a clear record of 1129 freshwater input and brackish water conditions due to freshwater-seawater mixing in a 1130 humid climate with high annual precipitation. This finding requires that the climate during deposition was significantly wetter than the present day arid climate of the study area, consistent with other studies that document a humid climate with widespread freshwater lakes in the western and southwestern U.S. during late Miocene to early Pliocene time.

5. Mixing of carbonate and siliciclastic sediment was most common during transgression. The relative percentages of carbonate-siliciclastic grains is a function of siliciclastic input from catchment sources, in situ carbonate production, tidal mixing, and relative sea level.

6. Facies variability is pronounced at bedform, outcrop, and basin scales: individual foresets are segregated into their carbonate-siliciclastic fractions, siliciclastic-rich strata pass laterally into carbonate-rich strata over $<200 \mathrm{~m}$ along strike, and siliciclastic-rich tidal flats (FA1) are present at the same stratigraphic level as carbonate-rich tidal flats (FA3) over just $\sim 2 \mathrm{~km}$ along strike of the palaeo shoreline. Low-gradient facies associations (this study) are present at the same stratigraphic level as facies recording transgression of a steep rocky shoreline on the opposite side of the basin. The observed facies variability along the margins of a tidal strait highlights the importance of characterising mixed carbonate- 
siliciclastic processes and environments for an improved understanding of mixedcomposition outcrops.

1149 We appreciate constructive reviews by Robert Dalrymple, Domenico Chiarella, Beatriz Bádenas 1150 and one anonymous reviewer. We also appreciate comments from Chief Editor Giovanna Della

1151 Porta and the Associate Editor John Reijmer. This study benefitted from discussion with Kevin 1152 Gardner, Malcolm Wallace, Murray Gingras, William Kearney, Kyle House, Brian Gootee, Jordan 1153 Bright, and many others. BOC thanks Logan Wetherell, Avery Maverick, Jordan Lanni, and 1154 Kristin Franks for field assistance. Funding was provided by the Society for Sedimentary Geology, 1155 International Association of Sedimentologists, Geological Society of America, and the National 1156 Science Foundation (grant EAR-1546006 to Dorsey). Ashleigh Hood acknowledges funding from 1157 a NASA Astrobiology Postdoctoral Fellowship and an Australian Research Council DECRA 1158 (DE190100988).

\section{Data availability statement}

1160 Data supporting the finding of this study are presented in this paper and in O'Connell et al., 2016 1161 (an open source thesis). Additional data that support the findings of this study are available from 1162 the corresponding author upon request.

\section{REFERENCES}

Ainsworth, R.B. (2010) Prediction of stratigraphic compartmentalization in marginal marine reservoirs. In: Reservoir Compartmentalization (Eds Jolley, S.J., Fisher, Q.J., Ainsworth, R.B., Vrolijk, P.J. and Delisle, S.), Geological Society of London Special Publication, 347, 199-218.

\section{Ainsworth, R.B., Hasiotis, S.T., Amos, K.J., Krapf, C.B., Payenberg, T.H., Sandstrom,} M.L., Vakarelov, B.K. and Lang, S.C. (2012) Tidal signatures in an intracratonic playa lake. Geology, 40, 607-610.

Alexandersson, T. (1972) Intragranular growth of marine aragonite and Mg-calcite: evidence of precipitation from supersaturated seawater. Journal of Sedimentary Research, 42, 441-460. 
Bádenas, B., Aurell, M. and Gasca, J.M. (2018) Facies model of a mixed clastic-carbonate, wave-dominated open-coast tidal flat (Tithonian-Berriasian, north-east Spain). Sedimentology, 65, 1631-1666. and Ilginé, R. (2019) How much can the occurrence and coverage of charophytes in an estuarine lagoon (Curonian Lagoon) be explained by environmental factors? Estuarine, Coastal and Shelf

Boersma, J. and Terwindt, J. (1981) Neap-spring tide sequences of intertidal shoal deposits in a mesotidal estuary. Sedimentology, 28, 151-170.

Booler, J. and Tucker, M.E. (2002) Distribution and geometry of facies and early diagenesis: the key to accommodation space variation and sequence stratigraphy: Upper Cretaceous Congost Carbonate platform, Spanish Pyrenees. Sedimentary Geology, 146, 225-247.

Brachert, T., Forst, M., Pais, J., Legoinha, P. and Reijmer, J. (2003) Lowstand carbonates, highstand sandstones? Sedimentary Geology, 155, 1-12.

Bray, N. (1988) Water mass formation in the Gulf of California. Journal of Geophysical Research: Oceans, 93, 9223-9240.

Breda, A. and Preto, N. (2011) Anatomy of an Upper Triassic continental to marginal-marine system: the mixed siliciclastic-carbonate Travenanzes Formation (Dolomites, Northern Italy). Sedimentology, 58, 1613-1647.

Bromley, R. (1996) Trace Fossils: biology, taphonomy and applications. Chapman and Hall, London, 361.

Bridge, J.S. (1993) Description and interpretation of fluvial deposits: a critical perspective. Sedimentology, 40, 801-810.

Bright, J., Cohen, A.S., Dettman, D.L. and Pearthree, P.A. (2018a) Freshwater plumes and brackish lakes: Integrated microfossil and $\mathrm{OC}-\mathrm{Sr}$ isotopic evidence from the late Miocene and early Pliocene Bouse Formation (California-Arizona) supports a lake overflow model for the integration of the lower Colorado River corridor. Geosphere, 14, 1875-1911.

Bright, J., Cohen, A.S. and Starratt, S.W. (2018b) Distinguishing brackish lacustrine from brackish marine deposits in the stratigraphic record: A case study from the late Miocene and early Pliocene Bouse Formation, Arizona and California, USA. Earth-Science Reviews, 185, 974-1003.

Bright, J., Cohen, A.S., Dettman, D.L., Pearthree, P.A., Dorsey, R.J. and Homan, M.B. (2016) Did a catastrophic lake spillover integrate the late Miocene early Pliocene Colorado River and the Gulf of California?: Microfaunal and stable isotope evidence from Blythe Basin, California-Arizona, USA. Palaios, 31, 81-91. 
Buising, A.V. (1990) The Bouse Formation and bracketing units, southeastern California and western Arizona: Implications for the evolution of the Proto-Gulf of California and the lower Colorado River. Journal of Geophysical Research: Solid Earth, 95, 20111-20132.

Cadée, G.C. (2007) Balanuliths: Free-living clusters of the barnacle Balanus crenatus. Palaios, 22, 680-681.

Castens-Seidell, B. (1984) Morphologies of Gypsum on a Modern Sabkha: Clues to Depositional Conditions. AAPG Bulletin, 68, 460-460.

Castens-Seidell, B. and Hardie, L.A. (1984) Anatomy of a Modern Marine Sabkha in a Rift Valley Setting, Northwest Gulf of California, Baja California, Mexico. AAPG Bulletin, 68, 460460.

Chapin, C.E. (2008) Interplay of oceanographic and paleopalaeoclimate events with tectonism during middle to late Miocene sedimentation across the southwestern USA. Geosphere, 4, 976991.

Chiarella, D., Longhitano, S.G. and Tropeano, M. (2019) Different stacking patterns along an active fold-and-thrust belt-Acerenza Bay, Southern Apennines (Italy). Geology, 47, 139-142.

Chiarella, D., Moretti, M., Longhitano, S.G. and Muto, F. (2016) Deformed cross-stratified deposits in the Early Pleistocene tidally-dominated Catanzaro strait-fill succession, Calabrian Arc (Southern Italy): Triggering mechanisms and environmental significance. Sedimentary Geology, 344, 277-289.

Chiarella, D., Longhitano, S.G., Sabato, L. and Tropeano, M. (2012) Sedimentology and hydrodynamics of mixed (siliciclastic-bioclastic) shallow-marine deposits of Acerenza (Pliocene, Southern Apennines, Italy). Italian journal of geosciences, 131, 136-151.

Chiarella, D. and Longhitano, S.G. (2012) Distinguishing Depositional Environments. In Shallow-Water Mixed, Bio-Siliciclastic Deposits On the Basis Of The Degree Of Heterolithic Segregation (Gelasian, Southern Italy). Journal of Sedimentary Research, 82, 969-990.

Chiarella, D., Longhitano, S.G. and Tropeano, M. (2017) Types of mixing and heterogeneities in siliciclastic-carbonate sediments. Marine and Petroleum Geology, 88, 617-627.

Choi, K.S. and Dalrymple, R.W. (2004) Recurring tide-dominated sedimentation in Kyonggi Bay (west coast of Korea): similarity of tidal deposits in late Pleistocene and Holocene sequences. Marine Geology, 212, 81-96.

Coueffe, R., Tessier, B., Gigot, P. and Beaudoin, B. (2004) Tidal Rhythmites as Possible Indicators of Very Rapid Subsidence in a Foreland Basin: An Example from the Miocene Marine 
Molasse Formation of the Digne Foreland Basin, SE France. Journal of Sedimentary Research 74, 746-759.

Crossey, L.C., Karlstrom, K.E., Dorsey, R., Pearce, J., Wan, E., Beard, L.S., Asmerom, Y., Polyak, V., Crow, R.S., Cohen, A., Bright, J. and Pecha, M.E. (2015) Importance of groundwater in propagating downward integration of the 6-5 Ma Colorado River system: Geochemistry of springs, travertines, and lacustrine carbonates of the Grand Canyon region over the past $12 \mathrm{Ma}$. Geosphere, 11, 660-682.

Crossey, L.C., Karlstrom K.E., Crow R.S., Ferguson, C., and Dorsey, R.J. (2017) Towards a depositional model for travertines of the Bouse Formation: examples from the southern Blythe Basin. In: Reynolds, R.E. (Ed.), 2017 Desert Symposium Field Guide and Proceedings, California State University Desert Studies Center, Zzyzx, CA, p. 174-179.

Dalrymple, R., Kurcinka, C., Jablonski, B., Ichaso, A. and Mackay, D. (2015) Deciphering the relative importance of fluvial and tidal processes in the fluvial-marine transition. In: Developments in Sedimentology, 68, pp. 3-45. Elsevier.

Dalrymple, R.W. (2010) Tidal depositional systems. In: Facies Models (Eds N.P. James and R.W. Dalrymple), Geological Association of Canada, 4, 201- 231.

Dalrymple, R.W., Makino, Y. and Zaitlin, B.A. (1991) Temporal and spatial patterns of rhythmite deposition on mud flats in the macrotidal Cobequid Baya Salmon river estuary, Bay of Fundy, Canada. In: Clastic Tidal Sedimentology (Eds D.G. Smith, G.E. Reinson, B.A. Zaitlin and R.A. Rahmani), 16, pp. 137-160. Canadian Society Petroleum Geologists Memories.

Dalrymple, R.W. and Rhodes, R.N. (1995) Estuarine dunes and bars. In: Geomorphology and sedimentology of estuaries (Ed. G.M.E. Perillo), 53, pp. 359-422. Elsevier, Amsterdam.

Dashtgard, S.E. and Gingras, M.K. (2005) Facies architecture and ichnology of recent saltmarsh deposits: Waterside Marsh, New Brunswick, Canada. Journal of Sedimentary Research, 75, 596-607.

Dashtgard, S.E. and La Croix, A.D. (2015) Sedimentological trends across the tidal-fluvial transition, Fraser River, Canada: a review and some broader implications. In: Fluvial-Tidal Sedimentology (Eds P.J. Ashworth, J.L. Best, D.R. Parsons), 68, pp. 111-126. Elsevier.

Davis, R.A.J. (2012) Tidal signatures and their preservation potential in stratigraphic sequences. In: Principles of Tidal Sedimentology (Eds R.W. Dalrymple and R.A.J. Davis), pp. 35- 55. Springer, New York.

Di Stefano, A. and Longhitano, S.G. (2009) Tectonics and sedimentation of the Lower and Middle Pleistocene mixed siliciclastic/bioclastic sedimentary successions of the Ionian Peloritani Mts (NE Sicily, Southern Italy): the onset of opening of the Messina Strait. Central European Journal of Geosciences, 1, 33-62. 
Dolan, J.F. (1989) Eustatic and tectonic controls on deposition of hybrid siliciclastic/carbonate basinal cycles: discussion with examples. AAPG Bulletin, 73, 1233-1246.

Dorsey, R.J. and Kidwell, S.M. (1999) Mixed carbonate-siliciclastic sedimentation on a 27, 935-938.

Dorsey, R.J., O'Connell, B., McDougall, K. and Homan, M.B. (2018) Punctuated sediment discharge during early Pliocene birth of the Colorado River: Evidence from regional stratigraphy, sedimentology, and paleontology. Sedimentary Geology. 363, 1-33.

Dorsey, R.J., O'Connell, B., Homan, M., and Bennett, S.E.K., (2017) Influence of the Eastern California Shear Zone on deposition of the Mio-Pliocene Bouse Formation: Insights from the Cibola area, Arizona. In: Desert Symposium Field Guide and Proceedings (Ed. Reynolds, R.E.) pp. 150-157.

Droser, M.L. and Bottjer, D.J. (1986) A semiquantitative field classification of ichnofabric. Journal of Sedimentary Research, 56, 558-559.

Ezcurra, E. and Rodrigues, V. (1986) Rainfall patterns in the Gran Desierto, Sonora, Mexico. Journal of Arid Environments, 10, 13-28.

Faulds, J.E., Schreiber, B.C., Langenheim, V.E., Hinz, N.H., Shaw, T.H., Heizler, M.T., Perkins, M.E., El Tabakh, M. and Kunk, M.J. (2016) Paleogeographic implications of late Miocene lacustrine and nonmarine evaporite deposits in the Lake Mead region: Immediate precursors to the Colorado River. Geosphere, 12, 721-767.

Flaig, P.P., Hasiotis, S.T., Prather, T.J. and Burton, D. (2019) Characteristics of a Campanian delta deposit controlled by alternating river floods and tides: the Loyd Sandstone, Rangely Anticline, Colorado, USA. Journal of Sedimentary Research, 89, 1181-1206.

Flügel, E. (2004) Microfacies Analysis of Carbonate Rocks. Analysis, Interpretation and Application, p. 976. SpringerVerlag, Berlin.

Folk, R.L. (1974) The natural history of crystalline calcium carbonate; effect of magnesium content and salinity. Journal of Sedimentary Research, 44, 40-53.

Forrester, R. (1991) Pliocene-climate history of the western United States derived from lacustrine ostracods. Quaternary Science Reviews, 10, 133-146

Foster, M., Riosmena-Rodriguez, R., Steller, D.L. and Woelkerling, W.J. (1997) Living rhodolith beds in the Gulf of California and their implications. Pliocene carbonates and related facies flanking the Gulf of California, Baja California, Mexico. Geological Society of America Special Paper, 318, 127-139. 
Gardner, K., and, Dorsey, R.J., (in press). Mixed carbonate-siliciclastic sedimentation at the margin of a late Miocene tidal strait, lower Colorado River Valley, southwestern USA. Sedimentology (accepted with minor revisions November 11, 2020).

Gingras, M.K. and MacEachern, J.A. (2012) Tidal ichnology of shallow-water clastic settings. In: Princip
Springer.

Gingras, M.K., MacEachern, J.A. and Dashtgard, S.E. (2012) The potential of trace fossils as tidal indicators in bays and estuaries. Sedimentary Geology, 279, 97-106.

Gingras, M.K., Pemberton, S.G., Saunders, T. and Clifton, H.E. (1999) The Ichnology of Modern and Pleistocene Brackish-Water Deposits at Willapa Bay, Washington: Variability in Estuarine Settings. 14, 352.

Ginsburg, R.N (1971). Landward movement of carbonate mud: new model for regressive cycles in carbonates. AAPG Bulletin, 55, 340-340.

Glenn, E.P., Nagler, P.L., Brusca, R.C. and Hinojosa-Huerta, O. (2006) Coastal wetlands of the northern Gulf of California: inventory and conservation status. Aquatic Conservation: Marine and Freshwater Ecosystems, 16, 5-28.

Gootee, B.F., Pearthree, P.A., House, P.K., Youberg, A., Spencer, J.E., and O'Connell, B. (2016) Geologic map of the Cibola $7 \frac{1}{2}$ ' Quadrangle and the northwestern part of Cibola SE 7 1 1 ', Quadrangle, La Paz County, Arizona, and Imperial County, California. Arizona Geological Survey Digital Map DGM-117, scale 1:24,000, with text.

Halfar, J., Ingle Jr, J.C. and Godinez-Orta, L. (2004) Modern non-tropical mixed carbonatesiliciclastic sediments and environments of the southwestern Gulf of California, Mexico. Sedimentary Geology, 165, 93-115.

Halfar, J., Strasser, M., Riegl, B. and Godinez-Orta, L. (2006) Oceanography, sedimentology and acoustic mapping of a bryomol carbonate factory in the northern Gulf of California, Mexico. Geological Society, London, Special Publications, 255, 197-215.

Hammersburg, S.R., Hasiotis, S.T. and Robison, R.A. (2018) Ichnotaxonomy of the Cambrian Spence Shale Member of the Langston Formation, Wellsville Mountains, Northern Utah, USA. Paleontological Contributions, 20, 1-66.

Häntzschel, W. (1975) Treatise on Invertebrate Paleontology: Miscellanea: Trace Fossils and Problematica. Pt. W. Suppl. 1. Geological Society of America.

Hardie, L.A. (1977) Sedimentation on the Modern Carbonate Tidal Flats of Northwest Andros Island, Bahamas: The Johns Hopkins University Studies in Geology. The Johns Hopkins University Press, Baltimore. 
1405 Hasiotis, S. (2002) Continental Trace Fossils: SEPM Short Course Notes, no. 51. Tulsa, 1406 Oklahoma, 134.

Hasiotis, S.T. and Mitchell, C.E. (1993) A comparison of crayfish burrow morphologies:

1409 Triassic and Holocene fossil, paleo-and neo-ichnological evidence, and the identification of their burrowing signatures. Ichnos: An International Journal of Plant \& Animal, 2, 291-314. 
Hauck, T.E., Dashtgard, S.E., Pemberton, S.G. and Gingras, M.K. (2009) Brackish-water ichnological trends in a microtidal barrier island-embayment system, Kouchibouguac National

Homan, M.B. (2014) Sedimentology and Stratigraphy of the Miocene-Pliocene Bouse Formation near Cibola, Arizona and Milpitas Wash, California: Implications for the Early Evolution of the Colorado River, Thesis University of Oregon.

House, P.K., Pearthree, P.A. and Perkins, M.E. (2008) Stratigraphic evidence for the role of lake spillover in the inception of the lower Colorado River in southern Nevada and western Arizona. Geological Society of America Special Papers, 439, 335-353.

Howard, K.A., House, P.K., Dorsey, R.J. and Pearthree, P.A. (2015) River-evolution and tectonic implications of a major Pliocene aggradation on the lower Colorado River: The Bullhead Alluvium. Geosphere, 11, 1-30.

\section{Ibarra, D.E., Oster, J.L., Winnick, M.J., Caves Rugenstein, J.K., Byrne, M.P. and} Chamberlain, C.P. (2018) Warm and cold wet states in the western United States during the Pliocene-Pleistocene. Geology, 46, 355-358.

Jackson, A.M., Hasiotis, S.T. and Flaig, P.P. (2016) Ichnology of a paleopolar, riverdominated, shallow marine deltaic succession in the Mackellar Sea: the Mackellar Formation (Lower Permian), central Transantarctic Mountains, Antarctica. Palaeogeography, Palaeoclimatology, Palaeoecology, 441, 266-291.

James, N.P. (1979) Shallowing-upward sequences in carbonates, In Facies Models (Ed R.G. Walker) Canadian Journal of Geosciences, pp. 108-119.

James, N.P. (1997) The cool-water carbonate depositional realm. In Cool-water Carbonates (Eds. N.P. James and J.A.D. Clarke, SEPM Special Publication, 56, 1-20.

James, N.P. and Lukasik, J. (2010) Cool-and cold-water neritic carbonates. In Facies models, 4 (Eds. R.W. Dalrymple and N.P. James) Geological Association of Canada, pp. 371-399. 
Kearney, W.S. and Fagherazzi, S. (2016) Salt marsh vegetation promotes efficient tidal channel networks. Nature Communications, 7, 12287.

Klein, G.D. (1970) Depositional and dispersal dynamics of intertidal sand bars. Journal of Sedimentary Research, 40, 1095-1127.

Klein, G.D. (1977) Clastic tidal facies: Champaign, Illinois. Continuing Education Publication Company, 149.

Kurcinka, C., Dalrymple, R.W. and Gugliotta, M. (2018) Facies and architecture of riverdominated to tide-influenced mouth bars in the lower Lajas Formation (Jurassic), Argentina. AAPG Bulletin, 102, 885-912.

Kvale, E.P., Bowie, C.M., Flenthrope, C., Mace, C., Parrish, J.M., Price, B., Anderson, S. and DiMichele, W.A. (2019) Facies variability within a mixed carbonate-siliciclastic sea-floor fan (upper Wolfcamp Fm., Permian, Delaware Basin, New Mexico). AAPG Bulletin, 104, 525563.

La Croix, A.D., Dashtgard, S.E., Gingras, M.K., Hauck, T.E. and MacEachern, J.A. (2015) Bioturbation trends across the freshwater to brackish-water transition in rivers. Palaeogeography, Palaeoclimatology, Palaeoecology, 440, 66-77.

Lavín, M. and Marinone, S. (2003) An overview of the physical oceanography of the Gulf of California. In: Nonlinear processes in geophysical fluid dynamics (Eds. O. Fuentes, J. Sheinbaum, and J. Torre) pp. 173-204. Springer.

Lavín, M., Godınez, V. and Alvarez, L. (1998) Inverse-estuarine features of the Upper Gulf of California. Estuarine, Coastal and Shelf Science, 47, 769-795.

Li, M.Z., Shaw, J., Todd, B.J., Kostylev, V.E. and Wu, Y. (2014) Sediment transport and development of banner banks and sandwaves in an extreme tidal system: Upper Bay of Fundy, Canada. Continental Shelf Research, 83, 86-107.

Lokier, S.W., Knaf, A. and Kimiagar, S. (2013) A quantitative analysis of Recent arid coastal sedimentary facies from the Arabian Gulf Coastline of Abu Dhabi, United Arab Emirates. Marine Geology, 346, 141-152.

Longhitano, S.G. (2011) The record of tidal cycles in mixed silici-bioclastic deposits: examples from small Plio-Pleistocene peripheral basins of the microtidal Central Mediterranean Sea. Sedimentology, 58, 691-719.

Longhitano, S.G., Chiarella, D., Di Stefano, A., Messina, C., Sabato, L. and Tropeano, M. (2012a) Tidal signatures in Neogene to Quaternary mixed deposits of southern Italy straits and bays. Sedimentary Geology, 279, 74-96.

Longhitano, S.G., Mellere, D., Steel, R.J. and Ainsworth, R.B. (2012b) Tidal depositional systems in the rock record: A review and new insights. Sedimentary Geology, 279, 2-22. 
Longhitano, S.G., Chiarella, D. and Muto, F. (2014) Three-dimensional to two-dimensional cross-strata transition in the lower Pleistocene Catanzaro tidal strait transgressive succession (southern Italy). Sedimentology, 61, 2136-2171.

Longhitano, S.G. and Nemec, W. (2005) Statistical analysis of bed-thickness variation in a Tortonian succession of biocalcarenitic tidal dunes, Amantea Basin, Calabria, southern Italy. Sedimentary Geology, 179, 195-224.

Longhitano, S.G., Sabato, L., Tropeano, M. and Gallicchio, S. (2010) A mixed bioclasticsiliciclastic flood-tidal delta in a micro tidal setting: depositional architectures and hierarchical internal organization (Pliocene, Southern Apennine, Italy). Journal of Sedimentary Research, 80, 36-53.

MacEachern, J.A., Bann, K.L., Gingras, M.K., and Pemberton, S.G., (2007) Applied Ichnology: SEPM, Short Course Notes 52, 380.

Marinone, S.G. (1997) Tidal residual currents in the Gulf of California: Is the M2 tidal constituent sufficient to induce them?. Journal of Geophysical Research. Oceans, 102, 86118623.

McDougall, K. and Martínez, A.Y.M. (2014) Evidence for a marine incursion along the lower Colorado River corridor. Geosphere, 10, 842-869.

McDougall, K., Reheis, M., Hershler, R. and Miller, D. (2008) Late Neogene marine incursions and the ancestral Gulf of California. Special Papers-Geological Society of America, 439, 355-373.

McNeill, D.F., Cunningham, K.J., Guertin, L.A., and Anselmetti, F.S. (2004) Depositional themes of mixed carbonate-siliciclastics in the South Florida Neogene: application to ancient deposits. In: Integration of Outcrop and Modern Analogues in Reservoir Modeling (Eds G.M. Grammer, P.M. Harris, G.P. Eberli,) AAPG Memoir 80, 23-43.

Meng, X., Ge, M. and Tucker, M.E. (1997) Sequence Sequence stratigraphy, sea-level changes and depositional systems in the Cambro-Ordovician of the North China carbonate platform. Sedimentary Geology, 114, 189-222.

Metzger, D.G., Loeltz, O.J. and Irelan, B. 1973. Geohydrology of the Parker-Blythe-Cibola area, Arizona and California. 2330-7102.

Metzger, D. (1968) The Bouse Formation (Pliocene) of the Parker-Blythe-Cibola area, Arizona and California. US Geological Survey Professional Paper, 600, D126-D136.

Miller, D.M., Reynolds, R.E., Bright, J.E. and Starratt, S.W. (2014) Bouse formation in the Bristol basin near Amboy, California, USA. Geosphere, 10, 462-475. 
Molnar, P. and Cane, M.A. (2007) Early Pliocene (pre-Ice Age) El Niño-like global climate: Which El Niño? Geosphere, 3, 337-365.

Michel, J., Borgomano, J., and Reijmer, J.J. (2018) Heterozoan carbonates: When, where and why? A synthesis on parameters controlling carbonate production and occurrences. EarthScience Reviews, 182, 50-67.

Morzaria-Luna, H.N., Castillo-López, A., Danemann, G.D. and Turk-Boyer, P. (2014) Conservation strategies for coastal wetlands in the Gulf of California, Mexico. 22, 267-288.

Mount, J. (1985) Mixed siliciclastic and carbonate sediments: a proposed first-order textural and compositional classification. Sedimentology, 32, 435-442.

Mount, J.F. (1984) Mixing of siliciclastic and carbonate sediments in shallow shelf environments. Geology, 12, 432-435.

Nio, S.D., and Yang, C.S. (1991). Diagnostic attributes of clastic deposits: a review. In: Clastic Tidal Sedimentology (Eds D.G. Smith, G.E. Reinson, B.A. Zaitlin and R.A. Rahmani), 16, pp 328, Canadian Society Petroleum Geologists Memories.

Norris, J.N. (2010). Marine algae of the Northern Gulf of California: Chlorophyta and Phaeophyceae. Smithsonian contributions to botany. 94, 1-276

Nyman, J.A., DeLaune, R.D., Roberts, H.H. and Patrick Jr, W. (1993) Relationship between vegetation and soil formation in a rapidly submerging coastal marsh. Marine Ecology Progress Series, 269-279.

O'Connell, B., Dorsey, R.J. and Humphreys, E.D. (2017) Tidal rhythmites in the southern Bouse Formation as evidence for post-Miocene uplift of the lower Colorado River corridor. Geology, 45, 99-102.

O'Connell, B. (2016). Sedimentology and depositional history of the Miocene-Pliocene southern Bouse Formation, Arizona and California. M.S. thesis, University of Oregon, Eugene, Oregon, $148 \mathrm{p}$.

Overstreet, R.B., Oboh-Ikuenobe, F.E. and Gregg, J.M. (2003) Sequence stratigraphy and depositional facies of Lower Ordovician cyclic carbonate rocks, southern Missouri, USA. Journal of Sedimentary Research, 73, 421-433.

Page, M.C. and Dickens, G.R. (2005) Sediment fluxes to Marion Plateau (southern Great Barrier Reef province) over the last $130 \mathrm{ky}$ : new constraints on 'transgressive-shedding' off northeastern Australia. Marine Geology, 219, 27-45.

Pemberton, S.G., Flach, P.D. and Mossop, G.D. (1982) Trace fossils from the Athabasca oil sands, Alberta, Canada. Science, 217, 825-827. 
Pemberton, S.G. and Wightman, D.M. (1992) Ichnological characteristics of brackish water deposits. In: Applications of Ichnology to Petroleum Exploration (Ed. S.G. Pemberton), SEPM Core Workshop, 17, 141-167.

Pemberton, S.G. (2001) Ichnology \& sedimentology of shallow to marginal marine systems.

Pilkey, O., Bush, D.M. and Rodríguez, R.W. (1988) Carbonate-terrigenous sedimentation on the north Puerto Rico shelf. In: Carbonate-Clastic Transitions (Eds. L.J. Doyle, H.H. Roberts), 42, pp. 231-250. Elsevier.

Piller, W.E. and Mansour, A.M. (1994) Origin and transport mechanisms of non-carbonate sediments in a carbonate-dominated environment (Northern Safaga Bay, Red Sea, Egypt). Abh Geol Bundesanstalt, 50, 369-379

Postma, G. (1990) An analysis of the variation in delta architecture. Terra Nova, 2, 124-130.

Pugh, D. (1987) Tides, surges and mean sea-level: a handbook for engineers and scientists. John Wiley, Chichester, UK. 472 pp.

Purser, B.H. (1973) The Persian Gulf: Holocene carbonate sedimentation and diagenesis in a shallow epicontinental sea. Springer-Verlag, New York, Heidelberg, Berlin, 471 pp.

Rankey, E.C. and Berkeley, A. (2012) Holocene carbonate tidal flats. In: Principles of Tidal Sedimentology (Eds R.W. Dalrymple and R.A.J. Davis), pp. 507-535. Springer.

Remeika, P., Fischbein, I.W. and Fischbein, S.A. (1988) Lower Pliocene petrified wood from the Palm Spring Formation, Anza Borrego Desert State Park, California. Review of palaeobotany and palynology, 56, 183-198.

Richard, S.M. (1993) Palinspastic reconstruction of southeastern California and southwestern Arizona for the middle Miocene. Tectonics, 12, 830-854.

Romano, M. and Whyte, M. (2015) A review of the trace fossil Selenichnites. Proceedings of the Yorkshire Geological Society, 60, 275-288.

Roskowski, J.A., Patchett, P.J., Spencer, J.E., Pearthree, P.A., Dettman, D.L., Faulds, J.E. and Reynolds, A.C. (2010) A late Miocene-early Pliocene chain of lakes fed by the Colorado River: Evidence from $\mathrm{Sr}, \mathrm{C}$, and $\mathrm{O}$ isotopes of the Bouse Formation and related units between Grand Canyon and the Gulf of California. GSA Bulletin, 122, 1625-1636.

Rubin, D.M. (2012) A unifying model for planform straightness of ripples and dunes in air and water. Earth-science Reviews, 113, 176-185.

Rubin, D.M. and Friedman, G.M. (1977) Intermittently emergent shelf carbonates: an example from the Cambro-Ordovician of eastern New York State. Sedimentary Geology, 19, 81-106. 

(2011) Climate and environment of a Pliocene warm world. Palaeogeography, Palaeoclimatology, Palaeoecology, 309, 1-8.

Sanders, D. and Höfling, R. (2000) Carbonate deposition in mixed siliciclastic-carbonate environments on top of an orogenic wedge (Late Cretaceous, Northern Calcareous Alps, Austria). Sedimentary Geology, 137, 127-146.

Sarjeant, W., Reynolds, R. and Kissell-Jones, M. (2002) Fossil creodont and carnivore footprints from California, Nevada, and Wyoming. Between the Basins: Exploring the Western Studies Consortium, 37-50.

Sarjeant, W.A. and Reynolds, R. (2001) Bird footprints from the Miocene of California. In: The changing face of the east Mojave Desert: abstracts from the 2001 Desert Symposium, pp. 21-40. facies distribution and depositional controls of a siliciclastic-dominated example.

Sedimentology, 65, 1558-1589.

Sherrod, D.R. and Tosdal, R.M. (1991) Geologic setting and Tertiary structural evolution of southwestern Arizona and southeastern California. Journal of Geophysical Research: Solid Earth, 96, 12407-12423.

Shinn, E.A. (1983) Tidal flat environment. In: Carbonate depositional environments, AAPG Memoir, 33, 171-210.

Shinn, E.A. and Ginsburg, R. (1964) Formation of Recent dolomite in Florida and the Bahamas. AAPG Bulletin, 48, 547-547.

Smith, P.B. (1970) New evidence for a Pliocene marine embayment along the lower Colorado River area, California and Arizona. Geological Society of America Bulletin, 81, 1411-1420.

Spencer, J.E., Pearthree, P.A., House, P.K., Reheis, M., Hershler, R. and Miller, D. (2008) An evaluation of the evolution of the latest Miocene to earliest Pliocene Bouse lake system in the lower Colorado River valley, southwestern USA. Special Papers Geological Society of America, 439, 375.

1680

Spencer, J.E. and Jonathan Patchett, P. (1997) Sr isotope evidence for a lacustrine origin for the upper Miocene to Pliocene Bouse Formation, lower Colorado River trough, and implications 1681 

Roskowski, J.A. and Faulds, J.E. (2013) Review and analysis of the age and origin of the Pliocene Bouse Formation, lower Colorado River Valley, southwestern USA. Geosphere, 9, 444459.

Steinhardt, T., Karez, R., Selig, U. and Schubert, H. (2009) The German procedure for the assessment of ecological status in relation to the biological quality element "Macroalgae \& Angiosperms" pursuant to the European Water Framework Directive (WFD) for inner coastal waters of the Baltic Sea. Rostocker Meeresbiologische Beiträge, 22, 42.

Sztano, O. and de Boer, P.L. (1995) Basin dimensions and morphology as controls on amplification of tidal motions (the Early Miocene North Hungarian Bay). Sedimentology, 42, 665-682.

Tape, C.H., Cowan, C.A. and Runkel, A.C. (2003) Tidal-bundle sequences in the Jordan Sandstone (Upper Cambrian), southeastern Minnesota, USA: evidence for tides along inboard shorelines of the Sauk epicontinental sea. Journal of Sedimentary Research, 73, 354-366.

Tcherepanov, E.N., Droxler, A.W., Lapointe, P., Dickens, G.R., Bentley, S.J., Beaufort, L., Peterson, L.C., Daniell, J. and Opdyke, B.N. (2008) Neogene evolution of the mixed carbonate-siliciclastic system in the Gulf of Papua, Papua New Guinea. Journal of Geophysical Research: Earth Surface, 113, F01S21.

Thompson, R.S. and Fleming, R.F. (1996) Middle Pliocene vegetation: reconstructions, paleoclimatic inferences, and boundary conditions for climate modeling. Marine Micropaleontology, 27, 27-49.

Thompson, R.S. (1991) Pliocene environments and climates in the western United States. Quaternary Science Reviews, 10, 115-132.

Thompson, R.W. (1975) Tidal-flat sediments of the Colorado River delta, northwestern Gulf of California. In: Tidal Deposits (Ed R.N. Ginsburg), pp. 57-65. Springer.

Todd, B.J., Shaw, J., Li, M.Z., Kostylev, V.E. and Wu, Y. (2014) Distribution of subtidal sedimentary bedforms in a macrotidal setting: The Bay of Fundy, Atlantic Canada. Continental Shelf Research, 83, 64-85.

Turak, J. (2000) Re-evaluation of the Miocene. Pliocene depositional history of the Bouse Formation, Colorado River trough, southern Basin and Range (CA, NV, and AZ). MS thesis, Laramie, University of Wyoming.

Umhoefer, P.J., Darin, M.H., Bennett, S.E., Skinner, L.A., Dorsey, R.J. and Oskin, M.E. (2018) Breaching of strike-slip faults and successive flooding of pull-apart basins to form the Gulf of California seaway from ca. 8-6 Ma. Geology, 46, 695-698. 
1727 Van Siclen, D.C. (1958) Depositional topography-examples and theory. AAPG Bulletin, 42, 1728 1897-1913.

Wilson, J.L. (1967) Cyclic and reciprocal sedimentation in Virgilian strata of southern New Mexico. Geological Society of America Bulletin, 78, 805-818.

Winnick, M.J., Welker, J.M., and Chamberlain, C.P. (2013) Stable isotopic evidence of El Nio-like atmospheric circulation in the Pliocene western United States: Climate of the Past, 9, 903-912.

Wright, V. (1984) Peritidal carbonate facies models: a review. Geological Journal, 19, 309-325.

Zeller, M., Verwer, K., Eberli, G.P., Massaferro, J.L., Schwarz, E. and Spalletti, L. (2015) Depositional controls on mixed carbonate-siliciclastic cycles and sequences on gently inclined shelf profiles. Sedimentology, 62, 2009-2037.

Zullo, V. and Buising, A. (1989) An unusual species of the Balanus amphitrite Darwin complex (Cirripedia, Balanidea) from the ancestral Colorado river delta in western Arizona and southeastern California. Proceedings of the Biological Society of Washington, 102, 924-932.

Zuffa, G.G. (1980) Hybrid arenites; their composition and classification. Journal of Sedimentary Research, 50, 21-29. 